\title{
ESTUDO PRELIMINAR PARA A IMPLANTAÇÃO DE \\ CURSOS TÉCNICO DE ENFERMAGEM E AUXILIAR \\ DE ENFERMAGEM NO ESTADO DO PARANÁ
}

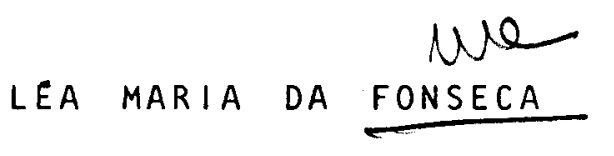

Dissertação de Mestrado apresentada à Faculdade de Saúde Pública da Universidade de São Paulo, Departaménto de Prática de Saūde Pública, para obtenção do tĩtulo de Mestre em Saūde Pública.

Orientadora: Dra. Nilce Piva Adami

\author{
São Paulo \\ 1978 \\ BIBLIOTECA
}

FACULDADE DE SAĹDE PÚBLICA 
A meus pais,

Estevãm e Doralina, pela satisfação que este trabalho lhes proporcionará $e$,

ao meu noivo, Nelson, pela compreensäo, carinho e apoio constantes. 


\section{Agradecimentos}

Expresso meus mais sinceros agradecimentos:

Ao Prof. Dr. Reinaldo Ramos, pela orientação inicial deste trabalho e, especificamente, pelo apoio constante ao meu aperfeiçoamento profissional.

A Dra. Nilce Piva Adami, pela continuidade da orientação deste trabalho $e$, em especial pelas valiosas sugestões oferecidas, as quais muito contribuiram ao enriquecimento do seu conteũdo.

A Irmã Maria Turkiewcz, Diretora da Escola Técnica de Enfermagem "Catarina Labourē", Curitiba, Paraná, por ter permitido a realização de um estudo sobre a situação da enfermagem a nível de sua Escola e pelas sugestões valiosas.

A Irmã Amélia Eva Sangali, Pedagoga, habilitada em Administração Escolar, da Escola Técnica de Enfermagem "Catarina Labouré"l, Curitiba, Paranā, pela colaboração prestada na fase de levantamento de dados.

A Dra. Ernestina Maurer Bastian, Enfermeira-Professora da Faculdade de Saúde Pública da Universidade de São Pau1o, pelo incentivo recebido. 
A Profa. Ana Maria dos Santos Amantino, Diretora do Departamento de Recursos Humanos da SUDESUL/MINTER, a quem devo a oportunidade de realizar o Curso de Pós-Graduação em Saúde pública. Sua confiança estimulou à realização deste trabatho.

Ao Dr. Waldemar Gonçalves da Silva, Superintendente Adjunto de Operações da SUDESUL/MINTER, pela colaboração recebida.

A Profa. Maria Alice Maciel Alves, Diretora da Divisão de Coordenação e Acompanhamento do DRH da SUDESUL/MINTER, pela revisão da redação.

A Sra. Mariza Martau, Bibliotecāria-Chefe da SUDESUL/ MINTER, pela revisão das referências bibliogrāficas.

Aos colegas do Departamento de Recursos Humanos da SUDESUL/MINTER, pelo apoio e estímulo prestados.

Aos tēcnicos do Grupo de Planejamento Setorial da Secretaria de Estado da Saúde e do Bem Estar Social do Paraná, pe la colaboração prestada na obtenção de dados.

A todos que, direta ou indiretamente, possibilitaram a realização deste trabalho, especialmente às docentes de enfermagem, enfermeiras e outros profissionais. 


\section{N D I C E}

Pàg.

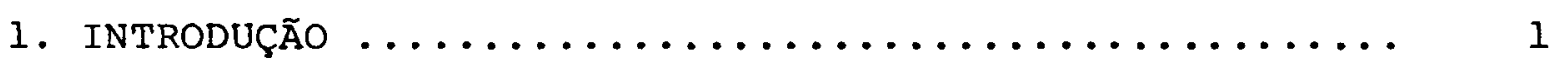

1.1 - Considerações Gerais ................... 1

1.2 - Justificativa $\ldots \ldots \ldots \ldots \ldots \ldots \ldots \ldots \ldots \ldots, 8$

2. PROPÓSITO E OBJETIVOS $\ldots \ldots \ldots \ldots \ldots \ldots \ldots \ldots \ldots \ldots \ldots, 12$

2.1 - Propósito $\ldots \ldots \ldots \ldots \ldots \ldots \ldots \ldots \ldots \ldots \ldots \ldots, 12$

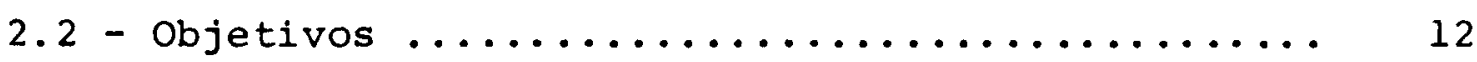

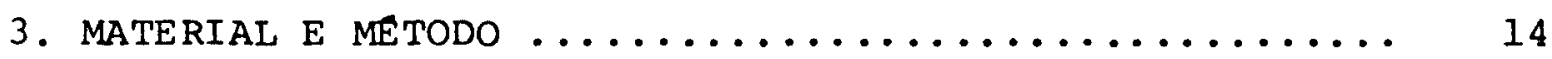

3.1 - Material .......................... 14

3.2 - Método $\ldots \ldots \ldots \ldots \ldots \ldots \ldots \ldots \ldots \ldots \ldots \ldots \ldots \ldots$

4. APRESENTAÇÃo E discuss ̃̃o dos RESUltados $\ldots \ldots \ldots \ldots \ldots$

4.1 - Situação da Capacidade de Formação na ETECLA .. 18

4.2 - Situação e Necessidade de Pessoal de Enfermagem no Estado do Paraná ................... 73

4.3 - Projeção de Necessidades de Recursos Humanos de Enfermagem no Estado do Paraná, em 1980 ...... 80 
Pág.

4.4 - Situação da Capacidade do Apare tho Formador do Ensino de Enfermagem a Nível de 28 Grau no Es-

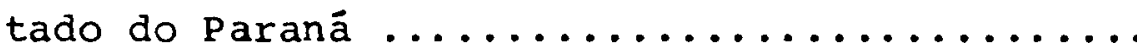

4.5 - Critērios para Seleção de Municípios, no Estado do Paraná, onde poderiam ser implantados os Cursos de Técnico e de Auxiliar de Enfermagem.

4.6 - Indicação de Municípios para a Implantação de Cursos Técnicos e de Auxiliares de Enfermagem no Estado do Paraná, a Curto e Médio Prazos .. 104

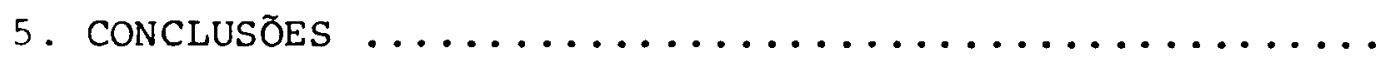

ANEXOS:

ANEXO 1 - Algumas Exigências para o Funcionamento de Curso de Enfermagem a Qualquer Nível ..... A-1

ANEXO 2 - Mapa do Estado do Paraná: Indicação de Municípios para a Implantação de Cursos Técnicos e de Auxiliares de Enfermagem, a Curto e Médio Prazos ................. A-11

ANEXO 3 - Modelos de Certificados e/ou Diplomas .... A-13

ANEXO $4-$ Ofícios $\ldots \ldots \ldots \ldots \ldots \ldots \ldots \ldots \ldots \ldots \ldots \ldots$ A-18 


\section{INDICE DE ILUSTRAÇÕES}

Pāg •

1 - Mapa do Estado do Paraná .............. A-12

2 - Modelos de Certificados e/ou Diplomas .......... A-14 


\section{INDICE DE TABELAS}

Pág.

TABELA 1 - Número de Vagas, de Matrículas Iniciais e Percentual de Vagas Ocupadas, no Curso de Técnico de Enfermagem, Sistema Regular, na ETECLA, no período de 1966 a $1977 . \ldots \ldots$

TABELA 2 - Número de Vagas, de Matrículas Iniciais e Percentual de Vagas Ocupadas, no Curso de Técnico de Enfermagem, Sistema Supletivo, na ETECLA, nos anos de 1973 a $1977 . \ldots$.

TABELA 3 - Número de Vagas, de Matrículas Iniciais e Percentual de Vagas Ocupadas, no Curso de Auxiliar de Enfermagem, na ETECLA, no período de 1956 a $1977 . \ldots \ldots \ldots \ldots \ldots \ldots$

TABELA 4 - Número de Matrículas Iniciais e de Aprovações, segundo as Séries do Curso de Técnico de Enfermagem, no Sistema Regular, Re provações e Evasões na ETECLA, no período de 1966 a $1977 . \ldots \ldots \ldots \ldots \ldots \ldots \ldots$

TABELA 5 - Número de Matrículas Iniciais e de Aprovações, segundo os Períodos ou semestres 
Pág.

do Curso Técnico de Enfermagem, no Sistema Supletivo, Reprovações e Evasões na ETECLA, nos anos de 1973 a $1977 . \ldots \ldots \ldots$

TABELA 6 - Número de Matrículas, de Aprovações, Reprovações e de Evasões do Curso de Auxiliar de Enfermagem na ETECLA, no período de 1956 a $1977 . \ldots \ldots \ldots \ldots \ldots \ldots \ldots$

TABELA 7 - Número de Matrículas Iniciais, de Aprovações e Indice de Aprovação, segundo as Sēries do Curso de Técnico de Enfermagem, Sistema Regular, na ETECLA, no período de 1966 a 1977.

TABELA 8 - Número de Matrículas Iniciais, de Aprovações e Indice de Aprovação, segundo os períodos do Curso de Técnico de Enfermagem, Sistema Supletivo, na ETECLA, nos anos de 1973 a $1977 . \ldots \ldots \ldots \ldots \ldots \ldots \ldots$

TABELA 9 - Número Total de Matrículas Iniciais, Aprovações e Indice de Aprovação, no Curso de Auxiliar de Enfermagem, na ETECLA, no período de 1956 a 1977 ...............

TABELA 10 - Número de Matrículas Iniciais, de Evasões e Indice de Evasão, segundo as Séries do Curso de Técnico de Enfermagem, Sistema Regular, na ETECLA, no período de 1966 a 1977. 
TABELA 11 - Número de Matrículas Iniciais, de Evasões e Indice de Evasão, segundo os Períodos do Curso de Técnico de Enfermagem, Sistema Supletivo, na ETECLA, nos anos de 1973

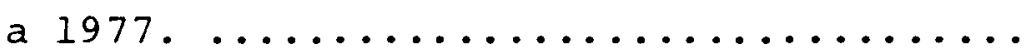

TABELA 12 - Número Total de Matrículas Iniciais, Evasões e Indice de Evasão no Curso de Auxiliar de Enfermagem da ETECLA, no período de 1956 a $1977 . \ldots \ldots \ldots \ldots \ldots \ldots \ldots \ldots$

TABELA 13 - Total de Turmas, de Matrículas e Média de Matrículas por Turma do Curso Técnico de Enfermagem, no Sistema Regular, na ETECLA, no período de 1966 a 1977 ........

TABELA 14 - Total de Turmas, de Matrículas e Média de Matrículas por Turma, do Curso Técnico de Enfermagem, no Sistema Supletivo, na ETECLA, no período de 1973 a $1977 . \ldots \ldots \ldots$

TABELA 15 - Total de Turmas, de Matrículas e Média de Matrículas por Turma do Curso de Auxiliar de Enfermagem na ETECLA, no período de

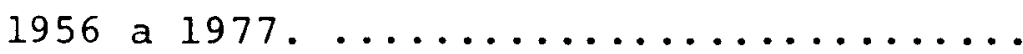

TABELA 16 - Nível de Escolaridade dos Alunos do Curso de Auxiliar de Enfermagem, na ETECLA, no

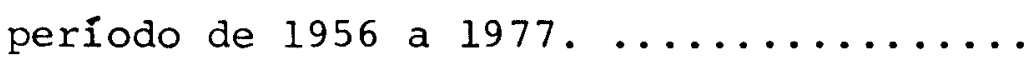


Pág.

de Enfermagem no Sistema Regular, na ETECLA, segundo os Estados, no período de 1966 a $1977 . \ldots \ldots \ldots \ldots \ldots \ldots \ldots \ldots \ldots$

TABELA 18 - Procedência dos Alunos do Curso Técnico de Enfermagem no Sistema Supletivo, na ETECLA, segundo os Estados, nos anos de 1973 a $1977 . \ldots \ldots \ldots \ldots \ldots \ldots \ldots \ldots \ldots \ldots \ldots$

TABELA 19 - Procedência dos Alunos do Curso de Auxiliar de Enfermagem, na ETECLA, no período de 1966 a $1977 \ldots \ldots \ldots \ldots \ldots \ldots \ldots$

TABELA 20 - Número de Docentes Enfermeiras, Total de Alunos e Proporção Professor/Aluno nos Cur sos de Técnico e de Auxiliar de Enfermagem, na ETECLA, no período de 1956 a 1977

TABELA 21 - Númeroe Distribuição de Docentes Enfermeiras para os Cursos de Técnico e de Auxiliar de Enfermagem, na ETECLA, segundo o Regime de Trabalho Semanal e Preparação-1977.

TABELA 22 - Matrículas, Alunos Concluintes, Repetentes, Evadidos, Total e Média do Custo/Aluno/Ano, a Preços Correntes e Constantes, do Curso Técnico de Enfermagem, no Sistema Regular, na ETECLA, no período de 1966 a 1977 .

TABELA 23 - Matrículas, Alunos Concluintes, Repetentes, Evadidos, Total e Média do Custo/Alu- 
Pág.

no/Ano, a Preços Correntes e Constantes, do Curso Técnico de Enfermagem, no Sistema Supletivo, na ETECLA, nos anos de 1974

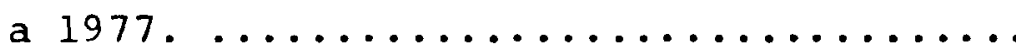

TABELA 24 - Nümero Total de Matrículas, Alunos Concluintes, Repetentes, Evadidos, Total e Média do Custo/Aluno/Ano, a Preços Correntes e Constantes, do Curso de Auxiliar de Enfermagem, na ETECLA, no período de

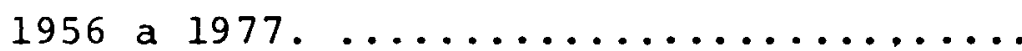

TABELA 25 - Distribuição dos Técnicos e Auxiliares de Enfermagem formados pela ETECLA, em ativi dade ou não, segundo o setor de trabalho 1977.

TABEla 26 - Fixação do Técnico e Auxiliar de Enfermagem no Mercado de Trabalho, segundo os Es tados - 1977 .

TABELA 27 - Prosseguimento de Estudos a Nível Superior do T'écnico e do Auxiliar de Enfermagem, formados na ETECLA, 1977. ..........

TABELA 28 - Recursos Humanos de Enfermagem destinados à Assistência Hospitalar, no Estado do Pa raná $-1974 . \ldots \ldots \ldots \ldots \ldots \ldots \ldots \ldots \ldots$

TABELA 29 - Disponibilidade e Necessidade de Recursos Humanos de Enfermagem na Assistência Hospitalar, no Estado do Paranā - 1974. ... 
TABELA 30 - Recursos Humanos de Enfermagem Destinados aos Serviços de Saúde Pública e Estabelecimentos Para-Hospitalares, no Estado do

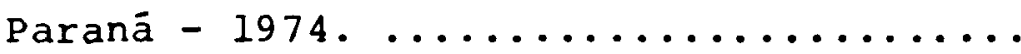

TABELA 31 - Disponibilidade e Necessidade de Recursos Humanos de Enfermagem para a Assistência em Serviços de Saúde Püblica e Estabelecimentos Para-Hospitalares, no Estado do

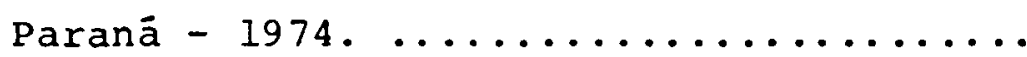

TABELA 32 - Projeção de Necessidades de Recursos Humanos de Enfermagem, para Assistência Hos pitalar, no Estado do Paranā, em 1980. . .

TABELA 33 - Projeção de Necessidades de Recursos Humanos de Enfermagem, para Assistēncia em Serviços de Saúde Pública e em Estabelecí mentos Para-Hospitalares, no Estado do Paranā, em 1980 .

TABElA 34 - Produção dos Cursos de Técnico de Enfermagem e de Auxiliar de Enfermagem, nos Sí temas Regular e Supletivo, no Estado do

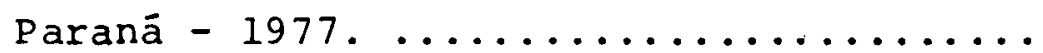

TABELA 35 - Relação de Municípios do Estado do Paraná com mais de 30.000 habitantes, segundo os Distritos Sanitários - 1975..........

TABELA 36 - Relação de Municípios do Estado do Paraná que apresentam um ou mais hospitais com mais de 100 leitos - 1975. ......... 
Pāg.

TABELA 37 - Relação de Municípios do Estado do Paraná, que apresentam população superior a 30.000 habitantes, hospitais que, em sua totalidade, possuam mais de 100 leitos, $\underline{u}$ ma ou mais Unidades Sanitārias e recursos humanos de enfermagem - 1975. ........

TABELA 38 - Relação de Municípios do Estado do Paraná, que apresentam população superior a a 30.000 habitantes, hospitais que em sua totalidade, possuam mais de 100 leitos, uma ou mais Unidades Sanitárias, uma ou mais enfermeiras, técnicos de enfermagem e uma ou mais escolas de ensino de 28 grau -

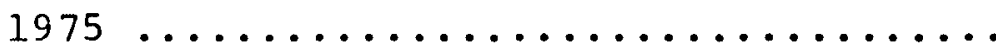




\section{RES U M O}

A autora descreve a situação da capacidade da ETECLA quanto à formação de Técnico de Enfermagem e de Auxiliar de Enfermagem desde a criação dos seus cursos até o ano de 1977. A seguir, faz um levantamento dos recursos humanos de enfermagem disponĩveis nas áreas hospitalares, para-hospitalares e de saúde pública no Estado do Paranā, no ano de 1974, bem como efetua uma projeção desses recursos para 1980, baseada nos padrões propostos pela OPS/OMS. Faz também um estudo da situação dos municípios desse Estado, a partir de critérios adotados, vi sando analisar os que apresentam condições essenciais para a implantação, a curto e médio prazos, dos Cursos de Técnico e de Auxiliar de Enfermagem. 


\section{$S \cup M M A R Y$}

The authoress describes the situation of ETECLA'S capacity as to the formation of technical and auxiliary health personnel since the creation of its courses until the year of 1977. Thereupon a data survey is made of the available nursing resources in the hospital, parahospital and public health areas in the State of Parana, in the year of 1974. Projections are made for 1980, based on the OPS/OMS standards. A study of the situation of the towns in this state is also carried out, based on adopted criteria aimed at the analysis of the ones which present essential conditions for the implantation of technical and auxiliary nursing courses on short and average terms. 


\title{
SIGLAS USADAS
}

\author{
ABEN - Associação Brasileira de Enfermagem \\ C.E.E - Conselho Estadual de Educação \\ C.F.E. - Conselho Federal de Educação
}

COREN/PR - Conselho Regional de Enfermagem do Estado do Paraná

DRHUS - Departamento de Recursos Humanos para a Saúde

ETECLA - Escola Técnica de Enfermagem "Catarina Labouré"

FIBGE - Fundação Instituto Brasileiro de Geografia e Estatística

MEC - Ministério da Educação e Cultura

NIERHS - Núcleo Integrado de Estudo de Recursos Humanos pạ ra a Saúde

OPS/OMS - Organização Panamericana da Saūde da organização Mundial da Saúde

SESB/PR - Secretaria de Estado da Saúde e do Bem Estar Social do Paraná. 


\section{INTRODUÇÃO}

\section{1 - Considerações Gerais}

O grau de desenvolvimento sócio-econômico de um país está estreitamente relacionado ao seu contingente de pessoal para as suas atividades, à maneira com que esse pessoal é utilizado em benefício da população e, especialmente, ao nível e à qualidade de sua preparação e treinamento. Na verdade, sua má ou precāria utilização, certamente, hā de influir negativamente no estabelecimento e expansão de serviços adequados, daí devendo resultar um agravamento de problemas, com sérias repercussões no desenvolvimento do país ${ }^{4}$.

No setor Saúde, não há dúvida que melhorias na saũde do povo são obtidas com a execução de melhores programas de saúde. E para a elaboração desses programas, bem como para a sua execução, há necessidade de pessoal de vários níveis adequadamente preparados.

De acordo com BRAGA ${ }^{4}$, todo país se defronta com problemas de recursos humanos para as atividades de saúde. 0 avanço das ciências e da tecnologia, ao lado de fatores sociológicos, está ocasionando, nos países mais desenvolvidos, uma defasagem crescente entre a demanda desses recursos e a capaci- 
dade de produção pelas organizações que os formam.

No Brasil, há necessidade de um equacionamento racional dos problemas relativos a recursos humanos, tendo-se, por isso, que planejar a melhor utilização daqueles disponíveis. Na área da saúde, essa necessidade se apresenta como um problema de utilização de pessoal capacitado para prestar serviços adequados à população, cujas necessidades bāsicas se tornam cada vez maiores e mais complexas.

Ressalta, ainda, a desarticulação existente entre o aparelho formador e utilizador dos recursos humanos do setor Saúde ${ }^{24}$.

Ainda segundo $\mathrm{BRAGA}^{4}$, devem constar como parte essencial dos programas de saúde, relacionando-se com seu planejamento e implementação, a educação e o treinamento do pessoal de saúde.

ALCANTARA enfatiza que a prestação de assistência médico-sanitāria, no país, é motivo de preocupação alarmante, face à crescente demanda atual e futura da população brasileira e tendo em vista o panorama precário de recursos humanos disponíveis para a saúde.

No Estado do Paraná, a situação dos recursos humanos para a saúde assemelha-se à observada no país, já que seus problemas se prendem à produção e utilização adequadas desses recursos, a partir da demanda e necessidades da população ${ }^{26}$.

Os recursos humanos são necessários em quantidade, qualidade, diversificação e proporcionalidade. Representam parcela apreciāvel, variando de 60 a $80 \%$ dos custos unitários de produção dos serviços de saúde ${ }^{47}$. 
o desenvolvimento do sistema de saúde está na dependência direta da capacitação dos recursos humanos empregados nas instituições mais significativas do setor. Assim sendo, de todos os elementos presentes numa instituição, o recurso humano é, como não poderia deixar de ser, o mais importante e o mais representativo.

Segundo ALCÂNTARA ${ }^{1}$, foi a partir da década de 40 que se começou a verificar que o número de enfermeiras necessārio aos serviços de saúde era insuficiente. Assim, foi dado início à preparação de pessoal auxiliar de enfermagem, para satisfazer às exigências crescentes, em termos de quantidade e de qualidade de pessoal.

A enfermagem, premida por uma série de fatores, tais como: luta por "status", necessidades regionais, nacionais e internacionais, progresso cientifico, recursos humanos de enfermagem e sua integração aos serviços médicos-sociais-assistenciais, tem procurado dar uma solução para enfrentar esta pro blemática ${ }^{1}$.

Os problemas de saúde existentes em nosso país atualmente, aliados à expansão dos serviços sanitários, decorrentes da valorização da saúde por parte da população e, ainda, ao crescimento demográfico (cuja taxa anual está na razão de, aproximadamente 2,98 no período de $60-70)^{1,19}$, influem sobre a qua lidade e a quantidade dos recursos humanos de enfermagem.

No Estado do Paraná, como nos demais estados da Região Sul, a problemática da saūde está a exigir medidas urgentes para o aumento dos recursos humanos habilitados. Face ao número insuficiente de enfermeiras, ALCANTARA ${ }^{1}$ frisa a importância da utilização de pessoal auxiliar de enfermagem para atender as exigências de saúde, cada vez maiores à medida que 
- grau de especialização da medicina se eleva e os serviços sanitários se expandem.

A necessidade de aumentar o ritmo de formação de pessoal de nível médio de enfermagem tem sido uma constante em todos os documentos técnicos e oficiais. A exemplo disso, destaca-se a IV Conferència Nacional de Saúde ${ }^{4}$, realizada em 1967, no Rio de Janeiro.

Atualmente, estamos vivendo uma política de educação que incorpora a preparação do pessoal de níveis tēcnico e auxiliar dentro do sistema de ensino.

A Lei 4.024, de 20 de dezembro de 1961 - Diretrizes e Bases da Educação Nacional ${ }^{32}$, que permitia a instalação de cursos técnicos, veio possibilitar a formação do técnico de enfermagem e procurou sanar a grande lacuna existente entre a enfermeira e o auxiliar de enfermagem. Infelizmente, mesmo em face da abertura dada pela Lei, pouquíssimos cursos foram instalados no País.

O inexpressivo número de técnicos de enfermagem, pessoal de nível intermediārio, faz com que muitos dos auxiliares de enfermagem se encontrem no exercício de funções para as quais não foram devidamente preparados ${ }^{1}$.

Com a Reforma de Ensino, a nova Lei de Diretrizes e Bases, Lei no 5.692, de 11 de agosto de $1971^{33}$, e Pareceres 699 de 06 de julho de 1972, 2.713 de 03 de setembro de 1974 e 3.814

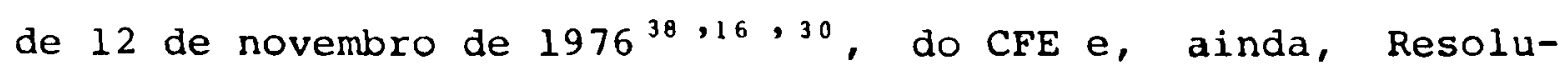

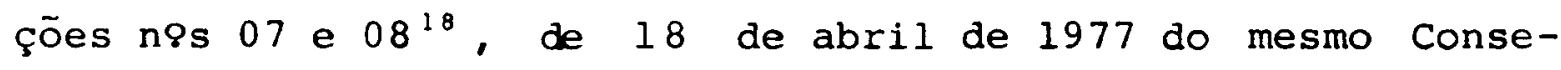
lho, os Cursos Técnicos tomaram nova orientação, principalmente no tocante às habilitações de 28 grau, o que se considera de grande valia para a composição da equipe de enfermagem, pa- 
ra a equipe de saúde, e conseqtentemente, para os serviços da comunidade.

A possibilidade atual de formação de pessoal de enfermagem se dá nos seguintes níveis $33,38,35,15,42,34,45,5$ :

- Enfermeira: com formação de nível superior, ou seja, 3o grau;

- Técnico de Enfermagem: com formação a nível de 28 grau, por sistemas regular ou supletivo, como habilitação ou como qualificação ;

- Auxiliar de Enfermagem:

- com formação a nível de 28 grau, por sistemas regular ou supletivo, como habilitação ou como qualificação;

- com formação a nível de 18 grau, "a título transitório e emergencial" podendo ser feita:

"a) ao nivel das 5a e 6 a séries do 1 o grau, em curso regular de dois anos letivos, de acordo com a Portaria MEC ne 106/65;

b) ao nivel das $7^{a}$ e $8^{a}$ séries do 1 o grau, em curso regular, também de dois letivos, conforme a mesma Portaria n: 106/65;

c) em cursos intensivos de onze meses, após conclusão do 1\% grau, conforme foi possibilitado pelo Parecer do Conselho Federal de Educação 
$75 / 70$

Alèm desses tipos de cursos de formação, há ainda a possibilidade do candidato se submeter a exame de supléncia profissionalizante, podendo, se aprovado, receber o titulo de Auxiliar de Enfermagem."142,

Terá certificado de validade apenas regional.

o campo de ação do pessoal de enfermagem não se diferencia fundamentalmente na extensão e sim na profundidade, isto é, todos os membros da equipe de enfermagem atuam no mesmo campo, distinguindo-se nas responsabilidades. Cabem as funções de maior complexidade à enfermeira, às intermediárias, ao técnico de enfermagem, e as mais simples, ao auxiliar de enfermagem $^{14}$.

O atendente, que também se inclui entre o pessoal de enfermagem, geralmente é alguém com instrução apenas primária, ou seja, 4ạ sērie do 18 grau, e, na grande maioria, inferior a essa, e que adquire, na prática, alguns conhecimentos e habilidades no campo da enfermagem ${ }^{14}$. Entretanto, atualmente, jā se cogita da possibilidade de prepará-los como auxiliares de enfermagem, desde que possuam o grau de escolaridade exigido, is-

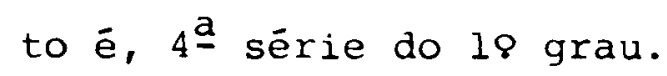

a) oguIsso, Taka. Considerações sobre a legislação do ensino e do exercício do técnico de enfermageme do auxiliar de en fermagem. Revista Brasileira de Enfermagem, Brasilia, $3 \overline{0}$ (2): $170,19 \overline{77}$. 
Em termos de planejamento, é preciso que sejam considerados os três níveis ${ }^{14}$, ou seja, o nível profissional, representado pela enfermeira, e os níveis ocupacionais, representados pelos técnicos de enfermagem e auxiliares de enfermagem. Desta forma, a formação não ficará ao sabor do impulso das dẹ cisões pessoais ou de determinadas comunidades.

Considerando que existe, ainda, um grande contingente de atendentes, treinados ou não, para as tarefas elementares de saúde, não se pode deixar de considerā-los, uma vez que, durante muito tempo, os serviços de saúde não poderão prescindir da colaboração desses elementos, face à escassez acentuada de recursos humanos de enfermagem habilitados.

Para o presente estudo, foi considerado apenas o nivel ocupacional, isto é, a formação do tēcnico de enfermagem e de auxiliar de enfermagem, no Estado do Paranā. Nesse Estado, a Escola Técnica de Enfermagem "Catarina Labourē" foi a mais indicada para este trabalho, por oferecer o ensino de enfermagem nos dois niveis ocupacionais; por apresentar condições técnico-administrativas, bem como por ser pioneira na realização do Curso Técnico de Enfermagem, com experiência acumulada no assunto. A soma de todos esses aspectos nos permitiu proceder a uma adequada avaliação a nível de escola, como ponto de partida para os estudos necessários ao estabelecimento de diretrizes na implantação dos cursos Técnico de Enfermagem e de Auxiliar de Enfermagem.

Foi efetuada, ainda, uma anālise da situação dos municípios no Paraná, com vistas a indicar aqueles que oferecem melhores condições de implantação de cursos, a curto e médio prazos. 


\section{2 - Justificativa}

- Conselho Estadual de Educação da Secretaria da Educação e Cultura do Estado do Rio Grande do Sul, mediante a Indicação n̊ 25, de 08 de março de $1974^{14}$, sugere orientação a ser adotada na formação de técnicos de enfermagem, para evitar que o ensino dessa modalidade de curso seja implantado de maneira desordenada, criando situações difíceis de serem corrigidas no futuro.

Esse Conselho estabeleceu as Diretrizes Gerais para - Planejamento da formação de Técnico e de Auxiliar de Enfermagem, tendo sido, para tal, assessorado por um grupo de enfermeiras, representantes da Escola de Enfermagem da Universidade Federal do Rio Grande do Sul, de Escolas de Auxiliar de Enfermagem do Estado, da Secretaria da Saúde do Estado do Rio Grande do Sul, da Organização Panamericana da Saúde da organização Mundial da Saúde, e da Superintendência do Desenvolvimento da Região Sul.

No Estado do Paranā, o Conselho Estadual de Educação da Secretaria da Educação e Cultura vem promovendo estudos, sob a orientação de sua assessora na área da Enfermagem, Irmã Maria Turkiewicz, cujos resultados subsidiaram a realização do presente trabalho.

No documento elaborado pelo Departamento de Recursos Humanos para a Saúde do Instituto Presidente Castello Branco, do Ministério da Saúde, intitulado "Breve Anälise de Mão-deObra do Setor Saüde Organizado" 25 , constata-se que, em 1970, para 100 profissionais de saúde, existiam:

- 7.5 técnicos

- 31.4 auxiliares de nível médio 
- 197.9 nível elementar

Para um enfermeiro, existiam, em $1970^{25,41}$ :

- $\quad 3.3$ auxiliares de enfermagem

- 0.7 práticos

- $\quad 8.6$ atendentes

- 11.5 outros auxiliares

O estudo para a implantação de Cursos de Técnico e de Auxiliar de Enfermagem, no Estado do Paraná, está fundamentado, também, no Plano Decenal de Saúde para as Américas, que faz, dentre outras, as seguintes recomendações sobre Enfermagem:

- "proporcionar a la población una atención de enfermeria libre de riesgos parael paciente en el $60 \%$ de los hospitales de 100 camas omäs, y en el $60 \%$ de los servicios de salud de la comunidad.

ESTO IMPLICA:

- Reducir en un $50 \%$ las infecciones adquiridas por los pacientes dentro del hospital.

- Reducir en un 50\% los accidentes ocurridos en los pacientes hospitalizados y las deformidades resultantes de una deficiente atención de enfermería.

- Lograr una fuerza laboral activaparaAmerica Latina y el Caribe en 1980 que represen te una proporción de 19 miembros del personal de enfermería por 10,000 habitantes. De ese grupo, 4.5 por 10,000 deberánser enfermeras.."

b) OPS/OMS. Plan decenal de salud para las Americas; informe final de la III Reunión Especial de Ministros de salud de las Américas. Washington, 1973. (Documento oficial, 118) p.68-9. 
Desse panorama, se depreende que se torna necessário

"intensificar a capacitação de pessoal de enfer magem, a fim de preparar, no decènio, 124.917 enfermeiros (dos quais $1 / 3$ poderá ser preparado a nivel superior e $2 / 3$ a nivel médiol e a 360.000 auxiliares de enfermagem"1 ${ }^{42}$, .

Na busca de solução dos problemas de saúde dos países em desenvolvimento, se tem demonstrado que o pessoal de enfermagem é essencial para a prestação do cuidado da saúde. o deficit de pessoal de enfermagem é ainda grande e persistente e se as metas dos planos de saúde dos países forem passíveis de serem atingidas, deverá haver uma definição quanto ao nível de assistência de enfermagem que cada um requer dentro de seu sistema de saúde, o tipo e o número de pessoal, os programas educacionais necessārios, e tomar as medidas correspondentes para levar isto à realidade ${ }^{43}$.

o País necessita de todas as categorias de pessoal de enfermagem; porém, a formação deste pessoal deverá ser feita de forma ordenada e dirigida, possibilitando o atendimento não só quantitativo, como também qualitativo da assistência de enfermagem prestada à população $1,14,43$.

Tendo em vista que no Estado do Paraná inexiste um estudo:

- sistemático retrospectivo da capacidade de formação do pessoal técnico e auxiliar de enfermagem a nível da Escola Técnica de Enfermagem "Catarina Laboure ${ }^{-1} d$.

c) oguisso, op.cit, p.172.

d) Quando, daqui em diante, se fizer referência à ETECLA, trata-se da Escola Técnica de Enfermagem "Catarina Labouré". 
- sobre a situação dos municípios relativa às condições mínimas para a implantação de cursos a nível de técnico e de auxiliar de enfermagem no Estado do Paraná;

Acredita-se que um estudo descritivo a respeito das condições mínimas para a implantação de cursos técnico e de auxiliar de enfermagem nos municípios do Estado do Paraná, contribuirá com alguns subsídios à Secretaria de Estado da Educação e da Cultura e ao Conselho Estadual de Educação, para o exame das possibilidades de criação e funcionamento dos referidos cursos. 


\section{PROPÓSITO E OBJETIVOS}

\section{1 - Propósito}

Fornecer subsidios para o estabelecimento de diretrizes gerais, com vistas à expansão e à melhoria da rede de ensino de enfermagem, a nível técnico e auxiliar, nos municípios do Estado do Paraná que apresentem os requisitos para a sua implantação, a curto e médio prazos.

$2.2-$ OBJetivos

2.2.1 - Identificar a situação da capacidade de formação da ETECLA, numa série histórica, desde o início da criação dos cursos de Técnico e de Auxiliar de Enfermagem.

2.2 .2 - Projetar para 1980 o número de enfermeiras, de técnicos e de auxiliares de enfermagem no Estado do Paranā, de acordo com os padrões propostos pela OPS/OMS, com base 
nos recursos humanos existentes em 1974 .

2.2.3 - Indicar os municípios que apresentam condições para a implantação de cursos de níveis técnico e de auxiliar de enfermagem, a curto e médio prazos, no Estado do Paranā, de acordo com os critérios estabelecidos. 


\section{MATERIAL E MÉTODO}

\section{1 - Material}

Trata-se de um estudo descritivo que pretende dimen-. sionar a expansão da rede de ensino de enfermagem a nivel de 28 grau, de acordo com a Lei n\& $5.692 / 71^{33}$ e Resoluções n\&s $07 / 77$ e 08/77-CFE ${ }^{18}$, tendo em vista o atendimento às necessí dades dos serviços de saūde nas āreas hospitalar, para-hospitalar e de saúde pública, no Estado do Paraná.

O material utilizado neste trabalho compreendeu informações obtidas a nível da ETECLA, localizada em Curitiba, $\mathrm{PR}$, e a nível do Estado do Paraná, com a utilização de dados secundários, obtidos nas seguintes fontes:

- Secretaria de Estado da Saúde e do Bem Estar Social do Paranā - SESB/PR.

- Fundação IBGE.

- Associação Brasileira de Enfermagem - Seção do Estado do Paranā - ABEn/PR.

- Secretaria de Estado da Educação e da Cultura do Paraná - SEEC/PR. 
- Conselho Federal de Educação - CFE

- Conselho Estadual de Educação/PR - CEE/PR

- Conselho Regional de Enfermagem/PR - CRE/PR

\section{2 - MÉtodo}

\section{2 .1 - A NİVEL DE EsCOLA}

Foi realizado um levantamento e análise da situação da capacidade de formação do técnico de enfermagem e de auxiliar de enfermagem da ETECLA, desde a sua criação até 1977.

Esse estudo retrospectivo inclui a análise de uma série histórica, contendo:

- histórico da criação, duração dos cursos, grau de escolaridade requerido e modalidades existentes

- número de vagas, de matrículas e percentual de vagas ocupadas

- número de matrículas, aprovações, reprovações e evasões

- índice de aprovação

- indice de evasão

- média de matrículas por turma

- nivel de escolaridade

- procedência dos alunos 
- corpo docente

- produção dos serviços educacionais da ETECLA

E efetuado, ainda, um levantamento e análise, em 1977, relativo:

- ao indice de fixação no mercado de trabalho

- ao prosseguimento de estudos a nível superior

\section{2 .2 - A nível de Estado}

Foi efetuado um levantamento, a partir de dados secundários de 1975, da situação dos municípios do Estado do Paraná, quantificando:

- população

- hospitais e leitos

- unidades sanitārias

- recursos humanos de enfermagem

- escolas de nível médio

A seguir, foi realizada a quantificação do pessoal de enfermagem disponível, proporcionalmente ao nümero de leitos hospitalares e à população do Estado do Paraná e sua necessidade segundo os padrões propostos pela OPS/OMS ${ }^{43}$.

Posteriormente, foi efetuada uma projeção para 1980 , de necessidades de pessoal de enfermagem em relação ao número de leitos e à população do Estado do Paranā. Por outro lado, o mesmo tratou de indicar as necessidades de pessoal de enfermagem para as áreas hospitalar, para-hospitalar e de saúde pú- 
blica.

A seguir, foram adotados critérios para a implantação de cursos de Técnico e de Auxiliar de Enfermagem.

Finalmente, foram indicados aqueles municípios que apresentam condições mínimas para a implantação de cursos de Técnico e de Auxiliar de Enfermagem, a curto e médio prazos.

\section{2 .3 - Ámbito do Estudo}

A nivel de escola, o estudo da situação da capacidade de formação da ETECLA abrangeu os cursos de técnico e de Auxiliar de Enfermagem em funcionamento, a partir dos anos em que os mesmos foram criados.

A nível de Estado, foram obtidas informações sobre o número de municípios, sua população, dados do Setor Saúde e outras, extraidas das seguintes fontes:

- Fundação IBGE

- Secretaria de Estado da Saúde e do Bem Estar Social do Paraná - SESB/PR

- Associação Brasileira de Enfermagem - $A B E n / P R$

- Secretaria de Estado da Educação e da Cultura do Paraná - SEEC/PR

- Conselho Regional de Enfermagem do Paraná - CRE/PR

- Conselho Estadual de Educação do Paraná - CEE/PR

Esse estudo sobreos municípios abrangeu a sua totalidade em função dos critérios adotados. 


\title{
4. APRESENTACÃO E DISCUSSÃO DOS RESULTADOS
}

\section{1 - Situação da Capacidade de Formação na ETECLA}

\author{
4.1.1 - Histórico da criação, duração dos cursos, \\ grau de escolaridade requerido e modalida- \\ des existentes
}

a) Curso Técnico de Enfermagem

A formação do técnico de enfermagem é resultante de idéias inovadoras da Associação Brasileira de Enfermagem, jã de longa data, pois no IV Congresso Brasileiro de Enfermagem realizado na Bahia, em 1950, falou-se do ensino da enfermagem também a esse nível ${ }^{51}$.

A partir dessa data, quase todos os congressos abordaram esse assunto, intensificando-se em 1956 e, mais ainda, com a Lei 4.024 de 20 de dezembro de $1961^{32,51}$.

O XVII Congresso Brasileiro de Enfermagem, realizado na Guanabara, em 1965, recomendava às seções da ABEn oferecerem subsídios aos Conselhos Estaduais de Educação para a cria- 
ção de cursos Técnicos de Enfermagem nos respectivos Estados ${ }^{5}$.

Em Curitiba, a Mantenedora da Escola de Auxiliares de Enfermagem, Província Brasileira da Congregação das Irmãs (Filhas) de Caridade de São Vicente de Paula, a 08 de setembro de 1965, criava a Escola Técnica de Enfermagem "Catarina Labouré". Foi encaminhado ao Conselho Estadual de Educação pedido de organização do Curso Técnico de Enfermagem da ETECLA processo no 01, de 19 de fevereiro de 1966, do Conselho em referência.

Segundo FURTADO ${ }^{20}$, relator do $\mathrm{CEE} / \mathrm{PR}$, no seu Parecer n̊ 41 de 04 de março de 1966 dizia:

\begin{abstract}
"inexistindo técnicos de nível intermediärio, muitos dos enfermeiros de nivel superior estão exercendo funçōes aquëm de suas habilitaçōes, e muitos auxiliares de enfermagem se encontram no exercicio de funções técnicas para as quais não foram suficientemente preparados".
\end{abstract}

Ainda, dizia o Relator:

"o Conselho não só apóia a iniciativa, mas propõe-se a colaborar para que eles sejam definitivamente implantados no sistema de ensino do País e para que seja regulamentado oxercicio profissional". e

A formação do Técnico de Enfermagem no Estado do Paranā, com base no artigo no 104, da Lei n̊ $4.024^{32}$, de 20 de dezembro de 1961, foi iniciada através da Resolução no $05^{13}$, de 04 de março de 1966 do Conselho Estadual de Educação, que organizou o Curso Técnico de Enfermagem na ETECLA, em Curitiba,

e) FURTADo, Jucundino da Silva. Organização e autorização para funcionamento de curso experimental de técnico de enfermagem; Parecer 41/66. Critéria, Curitiba, (3):76, Jan./jun. 1976. 
com a duração de três anos, de formação especial e de educação geral de segundo ciclo. A referida Resolução foi homologada pela Secretaria de Estado da Educação e da Cultura, mediante a Portaria no $1.301^{44}$, de 21 de março de 1966.

Com a implantação da Lei 5.692 de 11 de agosto de $1971^{33}$ e Resolução no 02 de 27 de janeiro de $1972^{36}$, do Conse1ho Federal de Educação - C.F.E., os estabelecimentos de ensino do País que ministravam cursos de Técnico de Enfermagem, reorganizaram seu currículo, adequando-o ao Parecer no 45/72 ${ }^{35}$ do mesmo Conselho. No Paraná, foi reorganizado pelo Parecer n\& $18^{7}$, de 15 de março de 1973 do CEE/PR, em atendimento à nova legislação federal de ensino.

A partir de 1973, foi implantado o curso supletivo de Técnico de Enfermagem na função de qualificação, baseado no Parecer 699/72, Quadro 1, item 12 do $\mathrm{CFE}^{38}$, exigindo-se o $28 \mathrm{grau}$ completo, tendo aprovação definitiva a 08 de maio de 1974, pelo Parecer n\& 36 e Deliberação n\& 30 de 08 de maio de $1974^{\circ}$, do Conselho Estadual de Educação do Estado do Paraná.

o Parecer no 3.814 , de 12 de novembro de $1976^{30}$ do CFE aprovou novo currículo de habilitação profissional de Técnico de Enfermagem e, a 18 de abril de 1977, pela Resolução no $07^{18}$, instituiu novo currículo de Técnico de Enfermagem, definindo as cargas horárias destinadas à parte de formação especial e de estāgio supervisionado, face ao perfil do futuro elemento ocupacional.

A partir de 1975, a ETECLA amadureceu para uma outra experiência, ou seja, ensino modular ou escalonado, segundo o Parecer n8 $76^{9}$, de 11 de abril de 1975, do CEE/PR, com terminalidade: 


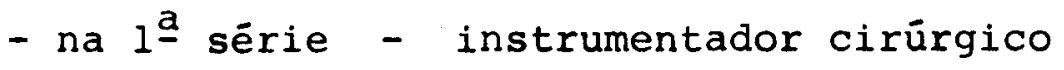

- na 2 a sērie - auxiliar de enfermagem

- na 3 à série - técnico de enfermagem

A mesma modalidade foi implantada em 1976 no ensino supletivo do mesmo estabelecimento, tendo para isso merecido a provação do CEE/PR pelo Parecer no $191^{10}$, de 21 de novembro de 1975, na formação de técnico de enfermagem - função qualificação, para portadores de conclusão de estudos de 28 grau, com dụ ração de 3 semestres ou períodos:

- 18 período - instrumentador cirúrgico

- 28 período - auxiliar de enfermagem

- 38 período - técnico de enfermagem

Em 1978, a ETECLA adequou seus currículos à Resolução n\& $07 / 77^{18}$ do $\mathrm{CFE}$, imprimindo-lhe novo enfoque. Teve aprovação, atravēs dos seguintes instrumentos legais:

- via regular: Parecer n\& $120^{12}$, de 03 de março de 1978, do Conselho Estadual de Educação do Paraná.

- via supletiva: Parecer no $70^{11}$ de 15 de fevereiro de 1978, do Conselho Estadual de Educação do Paraná.

b) Curso de Auxiliar de Enfermagem

A formação do Auxiliar de Enfermagem teve início com a Lei no $775^{27,42}$, de 06 de agosto de 1949 , a qual dispõe sobre o ensino de enfermagem no País e dá outras providèncias. A dura- 
ção, inicialmente em 18 meses, incluia apenas as disciplinas de enfermagem, tendo como exigência de escolaridade $\circ$ curso primário completo.

A Portaria n8 $106^{52,29,42}$, de 28 de abril de 1965, modificou o regime anterior. o Curso passou a ter duração de dois anos letivos de 180 dias cada um, abrangendo disciplinas de cultura geral, correspondentes às duas primeiras séries do curso ginasial e disciplinas específicas de enfermagem, sendo requisito para ingresso ao curso, o exame de admissão.

A expansão dos cursos intensivos teve início com 0 Parecer no $75^{52,42}$, aprovado em 30 de janeiro de 1970, pela Câa mara de Ensino Primário e Médio, do Conselho Federal de Educação. Com base neste Parecer, foi elaborado um "Guia para Curso Intensivo de Auxiliar de Enfermagem"139, em um Semináriode dois meses, promovido pelo Instituto Presidente Castello Branco, do Ministério da Saúde, que contou com a participação de 14 enfermeiras e/ou enfermeiras-professoras, procedentes das cinco regiões do País.

o "Guia" mencionado foi elaborado com a finalidade de servir como modelo geral para curso intensivo de auxiliar de enfermagem, recomendando-se sua prévia adequação às condifões regionais do mercado de trabalho e em particular à situa ção da unidade de ensino interessada na sua implantação ${ }^{39}$.

O Curso de Auxiliar de Enfermagem, em 1966, passou para o Sistema Estadual de Ensino e ajustou-se à Portaria n̊ 106, de 28 de abril de $1965^{52}$,29, do Ministērio da Educação e Cultura. Exigia a $1 \underline{a}$ e $2 \underline{a}$ sēries ginasial, feitas paralelamente.

No que se refere à situação do ensino de Auxiliar 
de Enfermagem na ETECLA, observa-se que, de 1956 a 1968, este Curso era de dois anos, sendo exigido o curso primário completo. A partir de 1966, os alunos ingressavam na ETECLA coma segunda série ginasial completa ou a faziam concomitantemente em outro gināsio de Curitiba. Em 1968, a execução do Curso passou a ter um calendário especial de 15 meses de duração. Em 1970, passou para 11 meses, mais 420 horas de estāgio de integração na empresa, com supervisão de enfermeira, exigindo-se dos alunos o curso ginasial completo, decorrente do Parecerno 93/68 ${ }^{6}$ do CEE/PR. Em 1973, o Curso foi reorganizado segundo a Lei $5.692 / 71^{33}$ e Parecer no $699 / 72^{38}$ do CFE, embora essa terminalidade não constasse no Catálogo das Habilitações constantes do Anexo $C$ do Parecer no 45 de 12 de janeiro de 1972 do $\mathrm{CFE}^{35}$. Foi programado para 1.140 horas, sendo $40 \%$ de teoria e 608 de prática, mais 210 horas de estágio de integração na empresa. Teve aprovação definitiva do CEE/PR, pelo Parecer no $36 / 74$ e Deliberação no $30 / 74^{8}$ do mesmo Conselho.

Com a Lei $5.692 / 71^{33}$, a partir do Parecer n8 $45 / 72^{35}$ do CFE, o Curso de Auxiliar de Enfermagem deixou de existir le galmente, por não estar contido na relação das habilitações pró postas. Essa situação perdurou até 12 de novembro de 1976 .

Com o aparecimento do Parecer $3.814^{30}$, de 12 de novembro de 1976, do CFE, ficou incluída essa habilitação na relação constante do Anexo $C$ do Parecer n8 $45 / 72^{35}$, tendo novamente validade nacional.

Para que os egressos de cursos de Auxiliar de Enfer magem, realizados no período de 1973 a 1976, fossem dotados de certificados com validade nacional, havia necessidade de validação de estudos, atendendo o Parecer n\& $3.814 / 76^{30}$ do CFE, Obedecido ao disposto na Portaria no $900^{28}$, de 03 de novembro 
de 1976, do MEC.

Na ETECLA, essa situação de validação de estudos foi decidida mediante o Parecer n8 $15 / 77$ - COLENE/DSU/MEC ${ }^{31}$.

A validação de estudos deve atender ao que estabelecem os artigos n8 38, 68 e 98 da Resolução n\& $07 / 77^{18}$ do CFE, ou seja:

"Art. 39- Os estudos correspondentes à habilitação de Auxiliar de Enfermagem terão a duração minima de 2.200 horas, assim distribuídas:

a) 1.090 horas para a parte de Educação Geral;

b) 1.110 horas para a de formação especial, das quais 400, no mínimo, destinar-se-ão ao Estágio Supervisionado.

Art. 60 - As matérias da parte de formação especial, para a habilitação parcial em Auxiliar de Enfermagem, serão retiradas do rol constante do artigo 5? ( $A$ e B), atendidos os interesses profissionais dos alunos e as exigencias do mercado de trabalho.

Art. 9: - os estudos pertinentes à habilitação de Auxiliar de Enfermagem visam a formar profissionais capazes de:

1. participar da equipe de saúde;

2. observar, reconhecer e descrever sintomas e prestar cuidados de higiene, conforto e tratamento simples, sob a supervisão do enfermeiro ou do técnico;

3. prosseguir no seu desenvolvimento integral como pessoa humana" ${ }^{18, f}$

f) EQUIVALÊNCIA de diversos cursos ao de auxiliar de enfermagem; Conselho Federal de Educação, resolução ne 07/77. Ensino Supletivo, Brasilia, $4(11): 30-1,1977$. 
A data da expedição dos certificados de Auxiliar de Enfermagem, a nível de $28 \mathrm{grau,} \mathrm{via} \mathrm{supletiva,} \mathrm{deverá} \mathrm{ser} \mathrm{pos-}$ terior a 12/11/76, data em que foi criado o seu curriculo minimo, para fins de validade nacional.

Por força do Parecer n̊ 1.446 , de 30 de maio de 1977, do CFE, item 4, todas as escolas, a partir de 1978, deverão adequar seus currículos de Cursos Técnico e de Auxiliar de Enfermagem à Resolução no $07 / 77^{18}$ do $C F E$, para que tenham validade nacional.

4.1.2 - NÚMERO DE VAgAs, DE MATRÍculas E PERCENTUAL DE VAGAS OCUPADAS

a) Curso Técnico de Enfermagem

\section{TABELA 1}

Nümero de Vagas, de Matrículas Iniciais e Percentual de Vagas ocupadas, no Curso de Técnico de Enfermagem, Sistema Regular, na ETECLA, no periodo de 1966 a 1977.

\begin{tabular}{c|c|c|c}
\hline \multirow{2}{*}{ P E R I O D O } & \multicolumn{3}{|c|}{ CURSO DE TECNICO DE ENFERMAGEM } \\
\cline { 2 - 4 } & N8 de Vagas (1) & $\begin{array}{c}\text { No de Matricu- } \\
\text { las Iniciais (2) }\end{array}$ & $\begin{array}{c}\text { \& de Vagas } \\
\text { Ocupadas }\end{array}$ \\
\hline $1966-1970$ & 245 & 206 & 84,1 \\
$1971-1975$ & 535 & 472 & 88,0 \\
$1976-1977$ & 280 & 301 & 107,5 \\
\hline T O T A L & 1.060 & 979 & 92,3 \\
\hline
\end{tabular}

Fonte: ETECLA - 1978

(1) Total de vagas nas três séries. (2) Total de matrículas nas três séries, mais transferências recebidas du rante o ano. 
Observa-se, na TABELA 1, um aumento do percentual de vagas ocupadas no periodo de 1966 a 1975, ou seja, de 84,18 para 88,08. Já no período de 1976 a 1977, O número de matrículas foi superior ao número de vagas previsto, dando um total de 107,58 de vagas ocupadas.

Essa tendência crescente do índice de vagas ocupadas oferece uma perspectiva satisfatória e pode ser decorrente da projeção da ETECLA na comunidade e da certeza de uma absorção imediata, do egresso, pelo mercado de trabalho existente.

A partir de 1973, a ETECLA deu início ao Curso de Técnico de Enfermagem, na função de qualificação, no sistema supletivo, para portadores de conclusão de estudos de 28 grau ou equivalente.

\section{TABELA 2}

Número de Vagas, de Matrículas Iniciais e Percentual de Vagas ocupadas, no Curso de Técnico de Enfermagem, Sistema supletivo, naETECLA, nos anos de 1973 a 1977.

\begin{tabular}{c|c|c|c}
\hline \multirow{2}{*}{ A N O S } & \multicolumn{3}{|c|}{ CURSO DE TECNICO DE ENFERMAGEM } \\
\cline { 2 - 4 } & No de Vagas (1) & $\begin{array}{c}\text { No de Matricu- } \\
\text { las Iniciais(2) }\end{array}$ & $\begin{array}{c}\text { \% de Vagas } \\
\text { Ocupadas }\end{array}$ \\
\hline 1973 & 80 & 61 & 76,2 \\
1974 & 100 & 114 & 114,0 \\
1975 & 100 & 98 & 98,0 \\
1976 & 120 & 130 & 108,3 \\
1977 & 120 & 108 & 90,0 \\
\hline T O T A L & 520 & 511 & 98,2 \\
\hline
\end{tabular}

Fonte: ETECLA - 1978

(1) Total de vagas nos três períodos ou semestres. (2) Total de matrículas iniciais nos três períodos ou semestres mais transferencias recebidas durante o ano. 
Verifica-se, na TABELA 2, no ano de 1973, 76,2\% de vagas ocupadas. Já nos anos de 1974 e 1976, o número de matrículas foi superior ao número de vagas previsto, ou seja, 114,08 e $108,3 \%$, respectivamente.

Cabe ressaltar que o Curso de Técnico de Enfermagem no sistema supletivo da ETECLA, a partir de 1975, é modular ao longo da formação do Técnico de Enfermagem, ou seja: no 18 período, o aluno obtém a habilitação como Instrumentador Cirūrgico; no 28 período, obtém habilitação como Auxiliar de Enfermagem e, no final do 38 período, obtēm habilitação como Técnico de Enfermagem.

b) Curso de Auxiliar de Enfermagem

\section{TABELA 3}

Nūmero de Vagas, de Matrículas Iniciais e Percentual de Vagas Ocupadas, no Curso de Auxiliar de Enfermagem, na ETECLA, no periodo de 1956 a 1977.

\begin{tabular}{l|c|c|c}
\hline \multirow{2}{*}{ P E R I O D O } & \multicolumn{3}{|c|}{ CURSO DE AUXILIAR DE ENFERMAGEM } \\
\cline { 2 - 4 } & $\begin{array}{c}\text { Nümero de } \\
\text { Vagas }\end{array}$ & $\begin{array}{c}\text { No de Matricu- } \\
\text { las Iniciais }\end{array}$ & $\begin{array}{c}\text { o de Vagas } \\
\text { Ocupadas }\end{array}$ \\
\hline $1956-1960$ & 178 & 277 & 155,6 \\
$1961-1965$ & 107 & 261 & 243,9 \\
$1966-1970$ & 210 & 306 & 145,7 \\
$1971-1975$ & 360 & 447 & 124,0 \\
$1976-1977$ & 100 & 95 & 95,0 \\
\hline T O T A L & 955 & 1.386 & 145,0 \\
\hline
\end{tabular}

Fonte: ETECLA - 1978 
Observa-se, na TABELA 3, no período de 1956 a 1965, uma tendência crescente do percentual de vagas ocupadas, ou seja, de 155,68 para 243,98 , como resposta, provavelmente, à maior divulgação e aceitação do curso. No entanto, no período de 1966 a 1977, houve uma redução significativa do percentual de vagas ocupadas, ou seja, de 145,78 para 95,08.

A criação dos cursos tēcnicos de enfermagem em 1966, no sistema regular e, em 1973, no sistema supletivo, poderia ser, em parte, responsável pela redução significativa do percentual de vagas ocupadas no curso de auxiliar de enfermagem.

Segundo o Núcleo Integrado de Estudo de Recursos Humanos para a Saúde (NIERHS) 24 , constata-se que, no Brasil, nos períodos compreendidos entre 1964 e 1970 e de 1966 e 1970, para os cursos de auxiliar e de técnico de enfermagem, respectivamente, houve uma evolução numérica das vagas e o aumento de candidatos foi proporcionalmente maior. No entanto, não houve preenchimento de todas as vagas disponíveis.

Comparando a situação encontrada na ETECLA, conforme as TABELAS 1, 2 e $3, \operatorname{com}$ a do estudo referido, pode-se dizer que há certa semelhança quanto ao Curso Técnico de Enfermagem. No entanto, para o Curso de Auxiliar de Enfermagem, pode-se afirmar que a ETECLA apresenta uma situação mais favorável. 
4.1 .3 - Número de matrículas, aprovações, rePROVAÇÕES E EVASÕES

\section{a) Curso Técnico de Enfermagem}

Verifica-se, na TABELA 4, no período de 1966 a 1975, ao se comparar o número total de matrículas iniciais com o número total de aprovações do Curso de Técnico de Enfermagem, no sistema regular, que há uma tendência crescente de evasão, ou seja, de 26 para 49. No entanto, se for comparado o número total de matrículas no período de 1966-70 com o de 1971-75, observa-se que, nesse último período, o aumento foi de mais de 1008 com relação ao número de matrículas e a evasão foi inferior a 1008 . Verifica-se, portanto, que a evasão se apresenta com uma tendência decrescente, podendo ser atribuida à melhor seleção dos candidatos pela ETECLA.

No período de 1971 a 1977, a evasão se apresenta, ainda, decrescente. Pode-se presumir, pelos dados do período de 1976-77, quando apenas dois anos são considerados, que a tendência da matrícula será ascendente e que a evasão poderá ser ligeiramente descendente, principalmente se for assegurada a continuidade de uma boa seleção inicial dos candidatos, bem como a manutenção eficiente dos Serviços de Orientação Educacional, de Coordenação Pedagógica e de Orientação Religiosa na ETECLA.

A evasão, no presente estudo, está representada pelo número de abandono ao Curso, mais transferências. Observa-se que a maior evasão se dá por abandono do Curso, ou seja, 82.

Quanto a reprovações, são insignificativas no período estudado. (TABELA 4) Em parte, essa situação pode ser atri- 
buỉa ao critério estabelecido pela ETECLA no que diz respeito ao aproveitamento do aluno, ou seja, quando o estudante é julgado inapto para a enfermagem, ele é orientado e encaminhado para outra habilitação, em outro estabelecimento.

Verifica-se, na TABELA 5, que o curso de técnico de enfermagem, no sistema supletivo, iniciado a partir de 1973, apresenta, também, uma tendência crescente da evasão, até o ano de 1975. Jã em 1976, há uma redução dessa evasão.

Embora haja evasões do 18 período para $\circ 28$ e do 28 para o 38 periodo ou semestre, è importante considerar que, a partir de 1975, o aluno, ao concluir qualquer um dos períodos referidos, recebe Certificado de Habilitação, correspondente ao módulo estudado. Ele está, portanto, capacitado para o ingresso imediato no mercado de trabalho, seja como instrumentador cirūrgico, seja como auxiliar de enfermagem ou como técnico de enfermagem, esse ūltimo se completar o 38 periodo. Ressalta-se, ainda, a oportunidade que a ETECLA propicia ao aluno de retornar à escola, em qualquer semestre, para o módulo seguinte. 


\section{TABELA 4}

Nümero de Matrículas Iniciaise de Aprovações, segundo as Séries do Curso de Técnico de Enfermagem, no Sistema Regular, Reprovações e Evasões na ETECLA, no perĩodo de

$$
\begin{array}{lllllllll}
1 & 9 & 6 & 6 & \text { a } & 1 & 9 & 7 & 7
\end{array}
$$

\begin{tabular}{|c|c|c|c|c|c|c|c|c|c|c|c|c|}
\hline \multirow[t]{2}{*}{$P E R I O D O$} & \multicolumn{2}{|c|}{ MATRICULAS } & \multicolumn{2}{|c|}{ INICIAIS } & \multicolumn{4}{|c|}{ APROVAÇÕES } & \multirow{2}{*}{$\begin{array}{l}\text { REPRO- } \\
\text { VAÇŐES }\end{array}$} & \multicolumn{3}{|c|}{ EVASÕES } \\
\hline & $\begin{array}{c}\text { aa } \\
\text { série }\end{array}$ & $\begin{array}{c}2 \underline{a} \\
\text { série }\end{array}$ & $\begin{array}{c}3 \underline{a} \\
\text { série }\end{array}$ & TOTAL & $\begin{array}{c}\text { lạ } \\
\text { série }\end{array}$ & $\begin{array}{c}2 \underline{a} \\
\text { série }\end{array}$ & $\begin{array}{c}3^{a} \\
\text { série }\end{array}$ & TOTAL & & Abandono & $\begin{array}{c}\text { Transfe- } \\
\text { rência }\end{array}$ & TOTAL \\
\hline $1976-1977$ & 133 & 97 & 71 & 301 & 113 & 86 & 66 & 265 & 4 & 26 & 6 & 32 \\
\hline $\mathrm{T} O \mathrm{TAL}$ & 449 & 304 & 226 & 979 & 371 & 276 & 217 & 864 & 8 & 82 & 25 & 107 \\
\hline
\end{tabular}

Fonte: ETECLA - 1978 


\section{TABELA 5}

Número de Matrículas Iniciais e de Aprovações, segundo os Perĩodos ou Semestres do Curso Técnico de Enfermagem, no Sistema Supletivo, Reprovações e Evasões na ETECLA, nos anos de 1973 a 1977.

\begin{tabular}{|c|c|c|c|c|c|c|c|c|c|c|c|c|}
\hline \multirow[t]{2}{*}{ P E R I O D O } & \multicolumn{4}{|c|}{ MATRICULAS INICIAIS } & \multicolumn{4}{|c|}{ APROVAÇÕES } & \multirow{2}{*}{$\begin{array}{l}\text { REPRO- } \\
\text { VAÇÕES }\end{array}$} & \multicolumn{3}{|c|}{ EVASÕES } \\
\hline & $\begin{array}{l}18 \text { pe } \\
\text { ríodo }\end{array}$ & $\begin{array}{l}28 \text { pe } \\
\text { ríodo }\end{array}$ & $\begin{array}{l}38 \text { pe } \\
\text { ríodo }\end{array}$ & TOTAL & $\begin{array}{l}18 \text { pe } \\
\text { ríodo }\end{array}$ & $\begin{array}{l}28 \text { pe } \\
\text { ríodo }\end{array}$ & $\begin{array}{l}38 \text { pe } \\
\text { ríodo }\end{array}$ & TOTAL & & Abandono & $\begin{array}{c}\text { Transfe- } \\
\text { rência }\end{array}$ & TOTAL \\
\hline 1975 & 36 & 27 & 35 & 98 & 29 & 25 & 33 & 87 & 1 & 10 & - & 10 \\
\hline 1976 & 56 & 52 & 22 & 130 & 52 & 50 & 21 & 123 & 2 & 4 & - & 4 \\
\hline 1977 & 37 & 29 & 42 & 108 & 33 & 29 & 38 & 100 & 1 & 7 & - & 7 \\
\hline
\end{tabular}

Fonte: ETECLA - 1978 . 
b) Curso de Auxiliar de Enfermagem

\section{TABELA 6}

Número de Matrículas, de Aprovações, Reprovações e de Evasões do Curso de Auxiliar de Enfermagem na ETECLA, no periodo de 1956 a 1977.

\begin{tabular}{l|c|c|c|c|c|c}
\hline \multirow{2}{*}{ PERIOdO } & \multicolumn{5}{|c|}{ CURSO DE } \\
\cline { 2 - 7 } & $\begin{array}{c}\text { Matricu- } \\
\text { culas }\end{array}$ & $\begin{array}{c}\text { Aprova- } \\
\text { çöes }\end{array}$ & $\begin{array}{c}\text { Repro- } \\
\text { vações }\end{array}$ & $\begin{array}{c}\text { Aban- } \\
\text { dono }\end{array}$ & $\begin{array}{c}\text { Transfe- } \\
\text { rências }\end{array}$ & TOTAL \\
\hline $1956-1960$ & 277 & 193 & 7 & 77 & - & 77 \\
$1961-1965$ & 261 & 193 & 5 & 63 & - & 63 \\
$1966-1970$ & 306 & 273 & 6 & 28 & 3 & 31 \\
$1971-1975$ & 447 & 398 & 9 & 33 & 3 & 36 \\
$1976-1977$ & 95 & 90 & 1 & 4 & - & 4 \\
\hline T O T A L & 1.386 & 1.147 & 28 & 205 & 6 & 211 \\
\hline
\end{tabular}

Fonte: ETECLA- 1978

* Iniciais

Observa-se, na TABELA 6, no período de 1956 a 1977 , ao se comparar o número total de matrículas iniciais com o número total de aprovações, que hã uma tendēncia decrescente da evasão, bastante acentuada, ou seja de 77 para 4. Pode-se atribuir essa situação a uma melhor seleção de candidatos, a incentivos, como bolsas de estudos e financiamentos, bem como a melhores oportunidades que o mercado de trabalho vem oferecen do. A própria valorização da profissão, pela comunidade, pode ser apontada, ainda, como uma das causas que incentiva o interesse do aluno na sua qualificação profissional, sem deixar de considerar, também a qualidade do corpo docente da ETECLA. Quan 
to ao nümero de reprovações, pode-se dizer que é insignificante.

Segundo o NIERHS ${ }^{24}$, a perda dos efetivos escolares me rece um atendimento especial, através da realização de estudos e pesquisas, para determinar causas e executar medidas preventivas da evasão. Verifica-se que a ETECLA apresenta essa mesma preocupação, tanto que mantēm em seu estabelecimento serviços de orientação educacional, coordenação pedagógica e serviço de orientação religiosa, como também efetua cuidadosa seleção ini cial de candidatos.

\section{1 .4 - INDICE DE APROVAGÃO}

a) Curso Técnico de Enfermagem

Constata-se, na TABELA 7, uma tendência crescente do índice de aprovação na primeira série do Curso Técnico de Enfermagem, no sistema regular, no período de 1966 a 1977, ou seja, de 80,48 para $84,9.8$.

Na segunda série, hã uma redução significativa desse indice e na terceira série, pode-se dizer que ele é mantido.

Considerando-se o total dos percentuais, no período estudado, verifica-se que o menor percentual ou indice de aprovações concentra-se na primeira série.

Deve-se isso, provavelmente, à imaturidade da clientela do ensino regular, que nem sempre opta pela enfermagem com inteira consciência do tipo de profissão que irá abraçar. 
Observa-se, na TABELA 8, que os maiores indices de aprovação do Curso de Técnico de Enfermagem, no sistema supletivo, estão nos dois ültimos semestres. Pode-se dizer, no entanto, que no período de 1973 a 1977, há um bom índice de aprovação, ou seja, superior a 808 . 


\section{TABELA 7}

Número de Matrīculas Iniciais, de Aprovações e Indice de Aprovação, segundo as Séries do Curso de Técnico de Enfermagem, Sistema Regular, na ETECLA, no período de

$$
\begin{array}{lllllllll}
1 & 9 & 6 & 6 & \text { a } & 1 & 9 & 7 & 7
\end{array}
$$

\begin{tabular}{|c|c|c|c|c|c|c|c|c|c|c|c|c|}
\hline \multirow{4}{*}{$P E R I O D O$} & \multicolumn{6}{|c|}{ C U R S O } & \multicolumn{6}{|c|}{$E N F E R M A G E M$} \\
\hline & \multirow{2}{*}{\multicolumn{4}{|c|}{ NO DE MATRICULAS INICIAIS }} & \multicolumn{8}{|c|}{$A P R O V A C O E S$} \\
\hline & & & & & \multicolumn{2}{|c|}{ lạ sērie } & \multicolumn{2}{|c|}{$2 \stackrel{\text { a }}{\text { série }}$} & \multicolumn{2}{|c|}{ 3̂ série } & \multicolumn{2}{|c|}{ Total } \\
\hline & $\begin{array}{c}\text { la } \\
\text { série }\end{array}$ & $\stackrel{2 \underline{a}}{\text { série }}$ & $\begin{array}{c}3^{a} \\
\text { sērie }\end{array}$ & TOTAL & NQ & 8 & N8 & 8 & NQ & 8 & NQ & 8 \\
\hline $1966-1970$ & 112 & 57 & 37 & 206 & 90 & 80,4 & 54 & 96,4 & 36 & 97,3 & 180 & 87,3 \\
\hline $1971-1975$ & 204 & 150 & 118 & 472 & 168 & 82,3 & 136 & 90,6 & 115 & 97,4 & 419 & 88,7 \\
\hline $1976-1977$ & 133 & 97 & 71 & 301 & 113 & 84,9 & 86 & 88,6 & 66 & 92,9 & 265 & 88,0 \\
\hline$T \circ T A L$ & 449 & 304 & 226 & 979 & 371 & 82,6 & 276 & 91,1 & 217 & 96,0 & 864 & 88,2 \\
\hline
\end{tabular}

Fonte: ETECLA - 1978 


\section{TABELA 8}

Nümero de Matrículas Iniciais, de Aprovações e Indice de Aprovação, segundo os perỉodos do Curso de Técnico de Enfermagem, Sistema Supletivo, na ETECLA, nos anos

$$
19733 \text { a } 1977 \text {. }
$$

\begin{tabular}{|c|c|c|c|c|c|c|c|c|c|c|c|c|}
\hline \multirow{4}{*}{$A N O S$} & \multicolumn{6}{|c|}{$C U R S O \quad D E$} & \multicolumn{6}{|c|}{ E N F E R M A G E M } \\
\hline & \multirow{2}{*}{\multicolumn{4}{|c|}{ N8 DE MATRICULAS INICIAIS }} & \multicolumn{8}{|c|}{$A P R O V A C \widetilde{O} E S$} \\
\hline & & & & & \multicolumn{2}{|c|}{18 período } & \multicolumn{2}{|c|}{28 período } & \multicolumn{2}{|c|}{38 período } & \multicolumn{2}{|c|}{ Total } \\
\hline & $\begin{array}{c}18 \\
\text { período }\end{array}$ & $\begin{array}{c}29 \\
\text { período }\end{array}$ & $\begin{array}{c}38 \\
\text { período }\end{array}$ & TOTAI & N8 & 8 & No & 8 & No & 8 & N8 & 8 \\
\hline 1973 & 33 & 28 & - & 61 & 28 & 84,8 & 27 & 96,4 & - & - & 55 & 90,1 \\
\hline 1974 & 47 & 40 & 27 & 114 & 40 & 85,1 & 35 & 87,5 & 26 & 96,3 & 101 & 88,6 \\
\hline 1975 & 36 & 27 & 35 & 98 & 29 & 80,5 & 25 & 92,6 & 33 & 94,2 & 87 & 88,7 \\
\hline 1976 & 56 & 52 & 22 & 130 & 52 & 92,8 & 50 & 96,1 & 21 & 95,5 & 123 & 94,6 \\
\hline 1977 & 37 & 29 & 42 & 108 & 33 & 89,2 & 29 & 100,0 & 38 & 90,4 & 100 & 92,6 \\
\hline $\mathrm{T} O \mathrm{TAL}$ & 209 & 176 & 126 & 511 & 182 & 87,1 & 166 & 94,3 & 118 & 93,6 & 466 & 91,1 \\
\hline
\end{tabular}

Fonte: ETECLA - 1978 
b) Curso de Auxiliar de Enfermagem

\section{TABela 9}

Número Total de Matrículas Iniciais, Aprovações e Indice de Aprovação, no Curso de Auxiliar de Enfermagem, na ETECLA, no período de 1956 a 1977.

\begin{tabular}{l|c|c|c}
\hline \multirow{2}{*}{ P E R I O D O } & \multicolumn{2}{|c}{ CURSO DE AUXILIAR DE ENFERMAGEM } \\
\cline { 2 - 4 } & $\begin{array}{c}\text { No Total de } \\
\text { Matriculas } \\
\text { Iniciais }\end{array}$ & N8 & \multicolumn{2}{|c}{ APROVAçÕES } \\
\cline { 2 - 4 } $1956-1960$ & 277 & 193 & 69,6 \\
$1961-1965$ & 261 & 193 & 73,9 \\
$1966-1970$ & 306 & 273 & 89,2 \\
$1971-1975$ & 447 & 398 & 89,0 \\
$1976-1977$ & 95 & 90 & 94,7 \\
\hline T O T A L & 1.386 & 1.147 & 82,7 \\
\hline
\end{tabular}

Fonte: ETECLA- 1978

Verifica-se, na TABELA 9, uma tendência crescente do indice de aprovação, no período estudado, ou seja, de 69,68 para $94,7 \%$. Nota-se, portanto, um aumento significativo do indice de aprovação no Curso de Auxiliar de Enfermagem. Pode-se inferir que essa situação favorável é decorrente de um programa adequado de recrutamento e seleção de candidatos, bem como atravēs dos Serviços existentes na ETECLA.

De acordo com o NIERHS ${ }^{24}$, a aumento de aprovações, tanto para os cursos de auxiliar como de técnico de enfermagem, embora superior às taxas correspondentes ao incremento demográ- 
fico do País, é nitidamente inferior às necessidades do sistema médico-sanitário da população.

Observa-se, pelas TABELAS, 7,8 e 9 , que no Curso Técnico de Enfermagem no sistema regular, os índices de aprovações oscilam de 87,38 para 88,78 e no sistema supletivo, oscilam de 88,68 para 94,68. Já no curso de Auxiliar de Enfermagem, os indices de aprovações oscilam de 69,6 a 94,78. Para os cursos técnicos, tanto nos sistemas regular como supletivo, na ETECLA, constata-se uma situação similar à encontrada no País. No entanto, para os cursos auxiliares de enfermagem, a evolução desse indice pode ser considerada como satisfatória.

\section{1 .5 - INDICE DE EVASÃO}

a) Curso Técnico de Enfermagem

Constata-se, na TABELA 10, que o maior indice ou percentual de evasão no Curso de Técnico de Enfermagem, sistema re gular, da ETECLA, no período estudado, se dá na primeira série, ou seja, 16,4\%, e o menor indice de evasão, na terceira sērie, com $3,5 \%$.

Observa-se, ainda, que, na primeira série, a evasão se mostra decrescente, enquanto que nas demais séries, se apresenta crescente, no período de 1966 a 1977, com exceção da 3a série, no período de 1971-75, que apresenta uma redução desse indice. Cabe ressaltar, ainda, que o índice total de evasão oscila entre 10,4 a 12,68 no referido período. 
Verifica-se, na TABELA 11, que no Curso de Técnico de Enfermagem, no sistema supletivo, ocorre situação idêntica à do Curso no sistema regular, ou seja, o maior percentual ou indice de evasão se dá no primeiro período. No entanto, é importante ressaltar que, no Curso a nível supletivo, o aluno que for aprovado no final de qualquer período recebe um Certificado de Habilitação, correspondente ao módulo concluído. Verifica-se, ainda, que o indice total de evasão oscila entre 3,1 a 10,2 , no período estudado. 


\section{TABELA 10}

Número de Matrículas Iniciais, de Evasões e Indice de Evasão, segundo as Séries do Curso de Técnico de Enfermagem, Sistema Regular, na ETECLA, no período de 1966
1

\begin{tabular}{|c|c|c|c|c|c|c|c|c|c|c|c|c|}
\hline \multirow{4}{*}{$\begin{array}{lllllll}P & E & R & I & O & D & O\end{array}$} & \multicolumn{6}{|c|}{$C \cup R S O$} & \multicolumn{6}{|c|}{ E N F E R M A G E M } \\
\hline & \multirow{2}{*}{\multicolumn{4}{|c|}{ NO DE MATRICULAS INICIAIS }} & \multicolumn{8}{|c|}{ E VAS $ठ \mathrm{ES}$} \\
\hline & & & & & \multicolumn{2}{|c|}{ lä série } & \multicolumn{2}{|c|}{$2 \underline{a}$ série } & \multicolumn{2}{|c|}{ 3̂ série } & \multicolumn{2}{|c|}{ Total } \\
\hline & $\begin{array}{c}1 \underline{a} \\
\text { série }\end{array}$ & $\begin{array}{c}2 \stackrel{a}{\text { série }} \\
\text { sén }\end{array}$ & $\begin{array}{c}3^{a} \\
\text { série }\end{array}$ & TOTAL & NQ & 8 & N8 & 8 & NQ & 8 & N8 & 8 \\
\hline $1966-1970$ & 112 & 57 & 37 & 206 & 23 & 20,5 & 2 & 3,5 & 1 & 2,7 & 26 & 12,6 \\
\hline $1971-1975$ & 204 & 150 & 118 & 472 & 34 & 16,7 & 13 & 8,6 & 2 & 1,7 & 49 & 10,4 \\
\hline $1976-1977$ & 133 & 97 & 71 & 301 & 17 & 12,7 & 10 & 10,3 & 5 & 7,0 & 32 & 10,6 \\
\hline$T O T A L$ & 449 & 304 & 226 & 979 & 74 & 16,4 & 25 & 8,2 & 8 & 3,5 & 107 & 10,9 \\
\hline
\end{tabular}

Fonte: ETECLA - 1978 
TABELA 11

Número de Matrículas Iniciais, de Evasões e Indice de Evasão, segundo os Perĩodos do Curso de Técnico de Enfermagem, Sistema Supletivo, na ETECLA, nos anos de $1973 \quad$ a 1977

\begin{tabular}{|c|c|c|c|c|c|c|c|c|c|c|c|c|}
\hline \multirow{4}{*}{$A N O S$} & \multicolumn{6}{|c|}{$C U R S O \quad D E$} & \multicolumn{6}{|c|}{$E N F E R M A G E M$} \\
\hline & \multirow{2}{*}{\multicolumn{4}{|c|}{ NO DE MATRICULAS INICIAIS }} & \multicolumn{8}{|c|}{$E \vee A S \widetilde{E} S$} \\
\hline & & & & & \multicolumn{2}{|c|}{18 período } & \multicolumn{2}{|c|}{ 20 período } & \multicolumn{2}{|c|}{39 período } & \multicolumn{2}{|c|}{ Total } \\
\hline & $\begin{array}{c}18 \\
\text { período }\end{array}$ & $\begin{array}{c}2 \% \\
\text { período }\end{array}$ & $\begin{array}{c}39 \\
\text { período }\end{array}$ & TOTAL & N8 & 8 & NQ & $q$ & N8 & 8 & N8 & 8 \\
\hline 1973 & 33 & 28 & - & 61 & 5 & 15,1 & 1 & 3,5 & - & - & 6 & 9,8 \\
\hline 1974 & 47 & 40 & 27 & 114 & 5 & 10,6 & 4 & 10,0 & - & - & 9 & 7,8 \\
\hline 1975 & 36 & 27 & 35 & 98 & 6 & 16,6 & 2 & 7,4 & 2 & 5,7 & 10 & 10,2 \\
\hline 1976 & 56 & 52 & 22 & 130 & 2 & 3,5 & 1 & 1,9 & 1 & 4,5 & 4 & 3,1 \\
\hline 1977 & 37 & 29 & 42 & 108 & 4 & 10,8 & - & - & 3 & 7,1 & 7 & 6,4 \\
\hline $\mathrm{T} O \mathrm{TAL}$ & 209 & 176 & 126 & 511 & 22 & 10,5 & 8 & 4,5 & 6 & 4,7 & 36 & 7,0 \\
\hline
\end{tabular}

Fonte: ETECLA- 1978 
b) Curso de Auxiliar de Enfermagem

\section{TABELA 12}

Número Total de Matrículas Iniciais, Evasões e Indice de Evasão no Curso de Auxiliar de Enfermagem da ETECLA, no período de 1956 a 1977.

\begin{tabular}{l|c|c|c}
\hline \multirow{2}{*}{ P E R I O D } & \multicolumn{2}{|c}{ CURSO DE AUXILIAR DE ENFERMAGEM } \\
\cline { 2 - 4 } & $\begin{array}{c}\text { No Total de } \\
\text { Matriculas } \\
\text { Iniciais }\end{array}$ & N8 & EVASÕES \\
\hline $1956-1960$ & 277 & 77 & 27,7 \\
$1961-1965$ & 261 & 63 & 24,1 \\
$1966-1970$ & 306 & 31 & 10,1 \\
$1971-1975$ & 447 & 36 & 8,0 \\
$1976-1977$ & 95 & 4 & 112 \\
\hline T O T A & 1.386 & & 15,2 \\
\hline
\end{tabular}

Fonte: ETECLA- 1978

Nota-se, na TABELA 12, uma tendência decrescente do índice de evasão do Curso de Auxiliar de Enfermagem, no período de 1956 a 1977, ou seja, de 27,78 para 4,28. Essa redução acen tuada do indice de evasão pode ser decorrente do bom programa de recrutamento e seleção dos candidatos, da melhoria do corpo docente, da metodologia empregada no desenvolvimento do curso, bem como dos próprios serviços criados na ETECLA para atender o aluno. 
O NIERHS ${ }^{24}$, em seu estudo, apresenta dados sobre a evasão dos educandos de enfermagem em nível técnico e auxiliar, no Brasil, no período de 1964 a 1970, constatando-se que, da lạ sērie para a $2 \stackrel{a}{\text {; }}$ há em termos médios uma perda da terça par te dos efetivos escolares, ou seja, em 1964 a matrícula na 1 a série do Curso de Auxiliar de Enfermagem era de 1.457 (100\%). Já em 1965, a matrícula na 2 a série era da ordem de 1.040, ou seja, 718. Quanto ao Curso Técnico de Enfermagem, em 1968, a matrícula na lạ série era de 137 (1008), na 2ấ série, 73, o que representa 53\%. Por outro lado, é verificado, ainda, que em nenhuma oportunidade a matrícula na 2 a série representou proporção superior a 718 da matrícula no primeiro ano.

Comparando-se os dados da ETECLA, contidos nas TABELAS 10, 11 e 12, com a situação discutida pelo NIERHS, pode-se dizer que a ETECLA apresenta-se com uma situação similar. No entanto, nota-se a diminuição progressiva da evasão. Pode-se a tribuir como causas da redução de evasões, tanto nos cursos técnico como no de auxiliar de enfermagem, além da melhor seleção de candidatos, os meios que a referida escola oferece, tais como bolsas de estudos, financiamentos e trabalhos remunerados. 


\section{1 .6 - MËDIA DE MATRÍCULAS POR TURMA}

a) Curso Técnico de Enfermagem

\section{TABELA 13}

Total de Turmas, de Matrículas e Média de Matrículas por Turma do Curso Técnico de Enfermagem, no Sistema Regular, na ETECLA, no período de 1966 a 1977.

\begin{tabular}{c|c|c|c}
\hline PERIODO & $\begin{array}{c}\text { TOTAL DE } \\
\text { TURMAS }\end{array}$ & $\begin{array}{c}\text { TOTAL DE } \\
\text { MATRICULAS }\end{array}$ & $\begin{array}{c}\text { MEDIA DE MATRI- } \\
\text { CULAS / TURMA }\end{array}$ \\
\hline $1966-1970$ & 12 & 206 & 17 \\
$1971-1975$ & 15 & 472 & 31 \\
$1976-1977$ & 7 & 301 & 43 \\
\hline T O T A L & 34 & 979 & 28 \\
\hline
\end{tabular}

Fonte: ETECLA - 1978

Verifica-se, na Tabela 13, que a maior média de matrículas/turma está no período de 1976-1977, ou seja, 43. Nota-se, ainda, um aumento da média de matrículas no período de 1966 a 1977. Pode-se atribuir esse aumento, em parte, à convicção, por parte da ETECLA, da necessidade de melhor aproveitamento dos seus recursos humanos e físicos, tornando, assim, - curso menos oneroso e possibilitando a formação de um número mais significativo, face às necessidades do sistema utilizador. Deve-se ainda, esse aumento, à melhor divulgação da ETECLA na comunidade e consequente maior procura dos jovens pelo curso profissionalizante de enfermagem. 


\section{TABELA 14}

Tota 1 de Turmas, de Matrículas e Média de Matriculas por Turma, do Curso Técnico de Enfermagem, no Sistema Supletivo, na ETECLA, no período de 1973 a 1977

\begin{tabular}{c|c|c|c}
\hline PERIODO & $\begin{array}{c}\text { TOTAL DE } \\
\text { TURMAS }\end{array}$ & $\begin{array}{c}\text { TOTAL DE } \\
\text { MATRICULAS }\end{array}$ & $\begin{array}{c}\text { MEDIA DE MATRI- } \\
\text { CULAS / TURMA }\end{array}$ \\
\hline $1973-1975$ & 5 & 273 & 54 \\
$1976-1977$ & 4 & 238 & 59 \\
\hline T O T A L & 9 & 511 & 56 \\
\hline
\end{tabular}

Fonte: ETECLA - 1978

Observa-se, na TABELA 14 , que a maior média de matrí culas/turma está no período de 1976 a 1977, ou seja, 59. Verifica-se, ainda, um aumento da média de matrículas/turma, no Cur so Técnico de Enfermagem, no sistema supletivo, no período de 1973 a 1977. Pode-se atribuir esse aumento à divulgação do Curso na comunidade; à praticidade do curso, que possibilita, ao egresso de 28 grau que não pretenda imediatamente prosseguir estudos de nível superior, obtenção de uma habilitação de instrumentador cirúrgico (no 18 módulo); auxiliar de enfermagem (no 28 módulo) ou técnico de enfermagem (no final do 39 módulo), proporcionando, assim, ao final de qualquer um dos semestres, uma ocupação de utilização imediata no mercado de trabalho.

Acredita-se que a ETECLA esteja convicta da necessidade de melhor aproveitamento de espaço físico, de recursos humanos e materiais, com vistas à redução do custo/aluno. Na parte prática, a ETECLA utiliza a proporção de, em média, 10 a 12 alunos/turma ${ }^{49}$. 
b) Curso de Auxiliar de Enfermagem

\section{TABELA 15}

Total de Turmas, de Matriculas e Média de Matrículas por Turma do Curso de Auxiliar de Enfermagem na ETECLA, no período de 1956 a 1977.

\begin{tabular}{c|c|c|c}
\hline PERIODO & $\begin{array}{c}\text { TOTAL DE } \\
\text { TURMAS }\end{array}$ & $\begin{array}{c}\text { TOTAL DE } \\
\text { MATRICULAS }\end{array}$ & $\begin{array}{c}\text { MEDIA DE MATRI- } \\
\text { CULAS / TURMA }\end{array}$ \\
\hline $1956-1960$ & 13 & 277 & 21 \\
$1961-1965$ & 12 & 261 & 21 \\
$1966-1970$ & 11 & 306 & 27 \\
$1971-1975$ & 11 & 447 & 40 \\
$1976-1977$ & 2 & 95 & 28 \\
\hline T O T A L & 49 & 1.386 & 47 \\
\hline
\end{tabular}

Fonte: ETECLA - 1978

Verifica-se, na TABELA 15, que a média de matrículas/turma aumenta de 21 para 47., no período de 1956 a 1977.

Esse aumento significativo da média de matrículas/ turma pode ser atribuido à necessidade de formar um número maior desse elemento ocupacional, face às necessidades dos serviços de saúde no Paraná. Considerando que, do total da carga horária, apenas 408 é destinada à parte teórica, acredita-se que a média encontrada na ETECLA é razoável, com vistas a reduzir o custo/ aluno. No entanto, os 608 da carga horária total, destinada à prática, é desenvolvida em turmas de 10 a 12 alunos/professor. 
Enfermagem ${ }^{40}$, verifica-se que para cursos dessa natureza deve ha ver, em média, de 8 a 10 alunos por professor, para a parte prática.

De acordo com os Indicadores de Educação ${ }^{21}$, turmas muito grandes limitam a atuação eficaz do professor, face à impossibilidade de atender igualmente a todos os alunos, bem como afetam a qualidade do ensino.

Considera, ainda, que a relação professor-aluno entre 20 e 35 proporciona uma situação eficaz do professor.

Observa-se, pelos resultados que o comportamento des sa variável está um tanto fora dos limites recomendados para a parte teórica, como para a parte prātica. No entanto, deve-se con siderar que a ETECLA conta com um corpo docente, cujo grau de qualificação, pode-se afirmar, como satisfatōrio, conforme se verifica pela TABELA 21 .

\section{1 .7 - NİVEL DE ESCOLARIDADE}

a) Curso de Técnico de Enfermagem

Aos alunos do Curso de Técnico de Enfermagem, no sistema regular da ETECLA, é exigido o Certificado de conclusão de estudos de 19 grau ou equivalente. Já para os alunos do Curso no sistema supletivo, função qualificação42,9 é exigido, como pré-requisito, o Certificado ou Diploma de conclusão de estudos de 28 grau ou equivalente.

g) Função Qualificação: tem por finalidade a qualificação para o trabalho, obrigatoriamente através de cursos, sem preocupação de educação geral. 
b) Curso de Auxiliar de Enfermagem

TABELA 16

Nivel de Escolaridade dos Alunos do Curso de Auxiliar de Enfermagem, na ETECLA, no período de 1956 a 1977

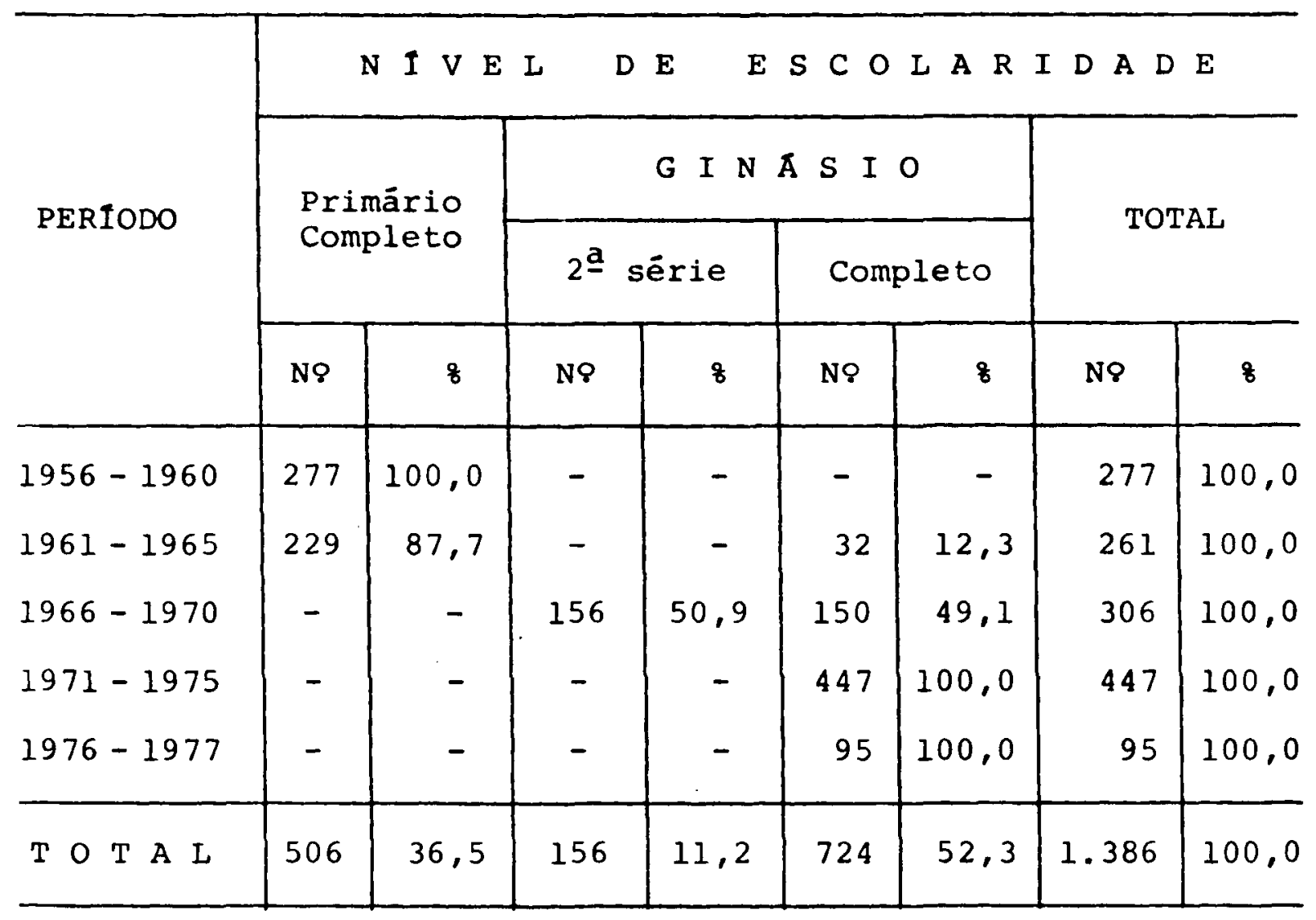

Fonte: ETECLA - 1978

Observa-se, na TABELA 16, que no período de 1956 a 1960, 1008 dos alunos possuia o antigo Curso Primário Completo; no período de 1961 a $1965,87,78$ possuia o curso referido e 12,38 o antigo Curso Ginasial completo. De 1966 a 1970, 50,98 possuia a $2^{\underline{a}}$ série do antigo ginásio e 49,18 apresentava conclu são deste curso. A partir de 1971, o grau de escolaridade exigido era o 19 grau completo, correspondente ao antigo primário e ginásio, resultando, assim, que 1008 dos alunos apresentasse esse nivel de instrução. 
Segundo a Lei no $775 / 49^{42}$, o grau de escolaridade exigido para o ingresso a esse curso era o de curso primário. Esse pré-requisito teve uma evolução progressiva.

De acordo com a Lei no $5.692 / 71^{33}$, Parecer no $699 / 72^{38}$ e Resolução no $07 / 77^{18}$ do C.F.E., os cursos de auxiliares de enfermagem a nível de $2 \%$ grau, têm como pré-requisito de escolaridade, o 19 grau completo ou equivalente. No entanto, pode haver curso de auxiliar de enfermagem emergencial, de acordo com a Resolução no $08 / 77^{18}$, do C.F.E. Este será a nível de 19 grau e de validade apenas regional, exigindo-se, no mínimo, a 4 à série, do lo grau.

Verifica-se, pela TABELA 16, que os alunos da ETECLA apresentam uma evolução crescente quanto ao nível de escolaridade segundo as normas dos instrumentos legais citados.

O aumento do grau de escolaridade propiciou, de certa forma, melhor planejamento e operacionalização do currículo plenoh $e$, consequlentemente, melhor aproveitamento por parte dos discentes. Por outro lado, maior nivel de escolaridade facilita o ensino $x$ aprendizagem e reduz a evasão, assimcomo facilita a adoção de novas metodologias específicas do ensino su pletivo.

(h) Entende-se por currículo pleno o conjunto de todas as atividades escolares, extra-classe e recursos em função do ensino $X$ aprendizagem. 


\title{
4.1 .8 - ProcedénCia doS ALUNOS
}

\author{
a) Curso Técnico de Enfermagem
}

Observa-se, na TABELA 17, no período de 1966 a 1977, um indice de 59,48 de procedência paranaense dos alunos do Curso Técnico de Enfermagem, no sistema regular. O restante fica dividido em ordem decrescente entre os Estados de Santa Catari na $(20,38)$; Rio Grande do Sul $(11,88)$; São Paulo $(4,78)$ e ou$\operatorname{tros}(3,88)$.

Com relação ao Curso Técnico de Enfermagem, no sistema supletivo, verifica-se na TABELA 18 que, como no sistema regular, o maior percentual está concentrado dentre os alunos de procedência paranaense, ou seja, 78,18, nos anos de 1973 a 1977. O restante fica dividido em ordem decrescente entre os Estados de Santa Catarina $(15,48)$ e Rio Grande do Sul $(5,38)$. Os demais são insignificativos.

b) Curso de Auxiliar de Enfermagem

Constata-se, na TABELA 19, no período de 1966 a 1977, um indice de 57,28 de procedência paranaense dos alunos do Curso de Auxiliar de Enfermagem. O restante fica dividido em ordem decrescente entre os Estados de Santa Catarina $(18,38)$ e Rio Grande do sul $(12,08)$.

AS TABELAS 17 e 18 mostram a procedência de alunos de outros estados, em especial a dos estados de Santa Catarina 
e do Rio Grande do Sul. Pode-se atribuir, em parte, à fixação das familias dos alunos no Paraná, principalmente na região Sudoeste. Por outro lado, nos estados em referência, esses cursos técnicos são muito recentes, com exceção de um, em Santa Catarina. Outro fator pode estar relacionado por ser a ETECLA dirigida por religiosas, contando, também, com alunos religiosos que constituem uma população flutuante, procedentes de diversos estados. Quanto aos alunos do Curso de Auxiliar de Enfermagem, verifica-se pela TABELA 19, o mesmo fenômeno. Devese, no entanto, ressaltar que esses cursos existem em todos esses estados. Talvez os recessos e as indecisões quanto ao nivel e duração dos cursos de auxiliar de enfermagem tenham canalizado alunos à ETECLA. 
TABELA $\cdot 17$

Procedencia dos Alunos do Curso Técnico de Enfermagem no Sistema Regular, na ETECLA, segundo os Estados, no periodo de 1966 a 1977

\begin{tabular}{|c|c|c|c|c|c|c|c|c|c|c|c|c|}
\hline \multirow{3}{*}{ PERIODO } & \multicolumn{4}{|r|}{$E$} & \multicolumn{6}{|c|}{$\begin{array}{llllll}S & \mathbf{T} & \mathrm{A} & \mathrm{D} & \mathrm{O} & \mathbf{S}\end{array}$} & \multirow{2}{*}{\multicolumn{2}{|c|}{$T O T A L$}} \\
\hline & \multicolumn{2}{|c|}{ Paraná } & \multicolumn{2}{|c|}{ Sta. Catarina } & \multicolumn{2}{|c|}{ R.G. do Sul } & \multicolumn{2}{|c|}{ São Paulo } & \multicolumn{2}{|c|}{ Outros } & & \\
\hline & N8 & 8 & N8 & 8 & N8 & 8 & No & 8 & No & 8 & No & 8 \\
\hline $1966-1970$ & 100 & 48,5 & 54 & 26,2 & 30 & 14,6 & 15 & 7,3 & 7 & 3,4 & 206 & 100,0 \\
\hline $1971-1975$ & 283 & 60,0 & 93 & 19,7 & 58 & 12,2 & 20 & 4,3 & 18 & 3,8 & 472 & 100,0 \\
\hline $1976-1977$ & 199 & 66,1 & 52 & 17,3 & 28 & 9,3 & 10 & 3,3 & 12 & 4,0 & 301 & 100,0 \\
\hline$T O T A L$ & 582 & 59,4 & 199 & 20,3 & 116 & 11,8 & 45 & 4,7 & 37 & 3,8 & 979 & 100,0 \\
\hline
\end{tabular}

Fonte: ETECLA - 1978 


\section{TABela 18}

Procedéncia dos Alunos do Curso Técnico de Enfermagem no Sistema Supletivo, na ETECLA, segundo os Estados, nos anos de 1973 a 1977

\begin{tabular}{|c|c|c|c|c|c|c|c|c|c|c|c|c|}
\hline \multirow{3}{*}{$A N O S$} & \multicolumn{4}{|r|}{$E$} & \multicolumn{6}{|c|}{$D \quad O \quad S$} & \multirow{2}{*}{\multicolumn{2}{|c|}{$\mathrm{T} O \mathrm{TAL}$}} \\
\hline & \multicolumn{2}{|c|}{ Paranā } & \multicolumn{2}{|c|}{ Sta. Catarina } & \multicolumn{2}{|c|}{ R.G. do Sul } & \multicolumn{2}{|c|}{ São Paulo } & \multicolumn{2}{|c|}{ Outros } & & \\
\hline & N8 & 8 & No & 8 & No & 8 & No & 8 & No & 8 & No & 8 \\
\hline 1973 & 50 & 81,9 & 11 & 18,1 & - & - & - & - & - & - & 61 & 100,0 \\
\hline 1974 & 81 & 71,0 & 28 & 24,6 & 3 & 2,6 & - & - & 2 & 1,8 & 114 & 100,0 \\
\hline 1975 & 98 & 100,0 & - & - & - & - & - & - & - & - & 98 & 100,0 \\
\hline 1976 & 80 & 61,5 & 30 & 23,1 & 20 & 15,4 & - & - & - & - & 130 & 100,0 \\
\hline 1977 & 90 & 83,4 & 10 & 9,3 & 4 & 3,7 & 2 & 1,8 & 2 & 1,8 & 108 & 100,0 \\
\hline$T O T A L$ & 399 & 78,1 & 79 & 15,4 & 27 & 5,3 & 2 & 0,4 & 4 & 0,8 & 511 & 100,0 \\
\hline
\end{tabular}

Fonte: ETECLA - 1978 


\section{TABELA 19}

Procedéncia dos Alunos do Curso de Auxiliar de Enfermagem, na ETECLA, no período de 1966 a 1977

\begin{tabular}{|c|c|c|c|c|c|c|c|c|c|c|c|c|}
\hline \multirow{3}{*}{ PERIODO } & \multicolumn{10}{|c|}{ 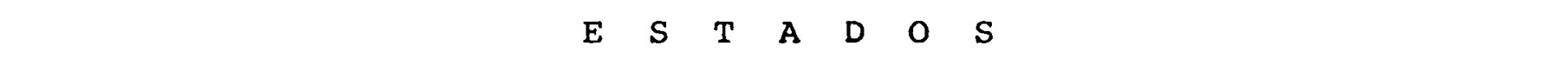 } & \multirow{2}{*}{\multicolumn{2}{|c|}{$T O T A L$}} \\
\hline & \multicolumn{2}{|c|}{ Paraná } & \multicolumn{2}{|c|}{ Sta. Catarina } & \multicolumn{2}{|c|}{ R.G. do Sul } & \multicolumn{2}{|c|}{ São Paulo } & \multicolumn{2}{|c|}{ Outros } & & \\
\hline & N8 & 8 & N8 & 8 & N8 & 8 & NQ & 8 & N8 & 8 & NQ & 8 \\
\hline $1966-1970$ & 173 & 56,5 & 52 & 17,0 & 36 & 11,8 & 24 & 7,8 & 21 & 6,9 & 306 & 100,0 \\
\hline $1971-1975$ & 255 & 57,0 & 83 & 18,6 & 56 & 12,5 & 22 & 4,9 & 31 & 6,9 & 447 & 100,0 \\
\hline $1976-1977$ & 57 & 60,0 & 20 & 21,1 & 10 & 10,5 & 4 & 4,2 & 4 & 4,2 & 95 & 100,0 \\
\hline$T \circ T A L$ & 485 & 57,2 & 155 & 18,3 & 102 & 12,0 & 50 & 5,9 & 56 & 6,6 & 848 & 100,0 \\
\hline
\end{tabular}

Fonte: ETECLA - 1978 
a) Número de Docentes - Enfermeiras e Proporção Professor/Aluno.

\section{TABELA 20}

Número de Docentes Enfermeiras, Total de Alunos e Proporção Professor/Aluno nos Cursos de Técnico e de Auxiliar de Enfermagem, na ETECLA, no periodo de

$$
1956 \text { a } 1977
$$

\begin{tabular}{c|c|c|c|c|c|c}
\hline & \multicolumn{2}{|c|}{ TECNICO DE ENFERMAGEM(1) } & \multicolumn{2}{|c}{ AUXILIAR } & \multicolumn{2}{c}{ DENFERMAGEM } \\
\cline { 2 - 7 } PERIODO & $\begin{array}{c}\text { No de } \\
\text { Docentes } \\
\text { Enferme } \\
\text { ras }\end{array}$ & $\begin{array}{c}\text { No } \\
\text { Total } \\
\text { de } \\
\text { Alunos }\end{array}$ & $\begin{array}{c}\text { Proporção } \\
\text { Profes- } \\
\text { sor/Aluno }\end{array}$ & $\begin{array}{c}\text { No de } \\
\text { Docentes } \\
\text { Enferme } \\
\text { ras }\end{array}$ & $\begin{array}{c}\text { No } \\
\text { Total } \\
\text { de } \\
\text { Alunos }\end{array}$ & $\begin{array}{c}\text { Proporção } \\
\text { Profes- } \\
\text { sor/Aluno }\end{array}$ \\
\hline $1956-1960$ & - & - & - & 37 & 277 & 7 \\
$1961-1965$ & - & - & - & 51 & 261 & 5 \\
$1966-1970$ & 55 & 206 & 4 & 59 & 306 & 5 \\
$1971-1975$ & 75 & 745 & 10 & 33 & 447 & 13 \\
$1976-1977$ & 58 & 539 & 9 & 23 & 95 & 4 \\
\hline T O T A L & 188 & 1.490 & 8 & 203 & 1.386 & 7 \\
\hline
\end{tabular}

Fonte: ETECLA - 1978

(1) No sistema regular e no sistema supletivo.

Verifica-se, na TABELA 20, que a relação professor/ aluno dos Cursos Técnicos de Enfermagem, nos sistemas regular e supletivo, varia de 4 a 10 , enquanto que no Curso de Auxiliar de Enfermagem varia de 4 a 13 e que a média geral é de 8 para os cursos técnicos e de 7 alunos/professor para os de au- 
xiliares de enfermagem.

De acordo com o Guia ${ }^{39}$, uma das condições essenciais ao bom desempenho do corpo docente é ser numericamente compatí vel com o total de alunos. Portanto, é recomendado, em média, uma proporção de professor/aluno de $1: 8$ a $1: 10$.

Desta forma, verifica-se que, para o Curso Técnico de Enfermagem, na ETECLA, no periodo de 1971 a 1977, a proporção está de acordo com os parâmetros referidos, ou seja, 9 e 10. Já para o curso de Auxiliar de Enfermagem, em nenhum dos períodos a proporção professor/aluno corresponde aos parâmetros mencionados.

Parece que esses resultados são demasiadamente baixos, em especial para o curso de Auxiliar de Enfermagem.

Segundo O NIERHS ${ }^{24}$, quando uma proporção se encontra abaixo do parâmetro estabelecido, ocasiona um ônus, pois aumenta o custo/aluno/ano. Por outro lado, quando excede ao estabelecido, pode prejudicar a qualidade do ensino, principalmente quando as características do mesmo são eminentemente teórico-práticas. Exemplo disso é o Curso de Auxiliar de Enfermagem, em que a maior carga horária é relativa à prática, ou seja, 608. No entanto, na ETECLA, verifica-se que, com exceção do Curso de Auxiliar de Enfermagem, no periodo de 1971 a 1975 , a relação professor/aluno esteve muito aquém da razão estabelecida:

b) Regime de Trabalho e Preparo do Corpo Docente 
de 1977, por não possuir a ETECLA informações completas necessárias à elaboração de uma série histórica.

\section{TABELA 21}

Número e Distribuição de Docentes Enfermeiras para os Cursos de Técnico e de Auxiliar de Enfermagem, na ETECLA, segundo o Regime de Trabalho Semanal e Preparação - 1977.

\begin{tabular}{|c|c|c|c|c|c|c|c|c|c|c|}
\hline \multirow{3}{*}{ DOCENTES } & \multicolumn{5}{|c|}{ REGIME DE TRABALHO SEMANAL } & \multicolumn{5}{|c|}{$P R E P A R A \& A 0$} \\
\hline & \multirow[b]{2}{*}{ No } & \multirow[b]{2}{*}{$(12 h)$} & \multirow[b]{2}{*}{$(22 h)$} & \multirow[b]{2}{*}{$(40 h)$} & \multirow{2}{*}{$\begin{array}{l}\text { Outros } \\
\text { Regimes }\end{array}$} & \multirow{2}{*}{$\begin{array}{l}\text { Diplo } \\
\text { madas }\end{array}$} & \multicolumn{3}{|c|}{$\begin{array}{c}\text { ESPECIAL IZADAS (3) } \\
\text { EM: }\end{array}$} & \multirow{2}{*}{$\begin{array}{l}\text { Somente } \\
\text { Licen- } \\
\text { ciadas } \\
\text { em En- } \\
\text { ferma- } \\
\text { gem }\end{array}$} \\
\hline & & & & & & & S.P. & obst. & $\begin{array}{c}\text { Psiquia- } \\
\text { tria }\end{array}$ & \\
\hline $\begin{array}{l}\text { Enfermei- } \\
\text { ras }\end{array}$ & 13 & 5 & 3 & 2 & 3 & (1) 3 & 1 & 3 & 1 & 5 \\
\hline $\begin{array}{l}\text { Técnicos } \\
\text { de } \\
\text { Enfermagem }\end{array}$ & 2 & - & 2 & - & - & (2) 2 & - & - & - & - \\
\hline TOTAL & 15 & 5 & 5 & 2 & 3 & 5 & 1 & 3 & 1 & 5 \\
\hline
\end{tabular}

Fonte: ETECLA- 1978

(1) Apenas graduadas em Enfermagem (2) Diploma de Habilitação de Técnico de Enfermagem (3) Todas licenciadas, com cursos a nível de especialização em Enfermagem de Saúde Pública, Ohstetrícia e Psiquiatria, sendo que uma enfermeira possui pós-graduação em obstetrícia.

Das 13 docentes-enfermeiras existentes em 1977 na ETECLA, verifica-se que prevalece o número de enfermeiras com re gime de trabalho de $12 \mathrm{~h}$ semanais. A seguir, figuram 6 enfermei ras, sendo 3 trabalhando em regime de $22 \mathrm{~h}$ semanais e 3 em outros regimes de trabalho. Apenas 2 enfermeiras trabalham em re 
gime de $40 \mathrm{~h}$ semanais.

Com referência aos técnicos de enfermagem com funções docentes (monitoria - supervisão nos estágios de introdução à enfermagem, saúde pública e centro cirūrgico para auxiliares de enfermagem), os mesmos estão contratados em regime de $22 \mathrm{~h}$ semanais.

Quanto ao preparo do corpo docente, observa-se que 3 enfermeiras possuem apenas o curso de graduação em enfermagem; 5 são somente licenciadas em enfermagem e 5 são, além de licenciadas, possuidoras de cursos de especialização em enfermagem de saūde püblica, obstetrícia e psiquiatria, sendo que 1 possui curso de pōs-graduação em obstetrícia.

De acordo com o Relatório da Comissão de Atividades Cientificas e Documentação da $A B E n^{46}$, referentes ao ano de 1976, o regime de trabalho de docentes situava-se entre 12 a 18 horas semanais nos cursos tēcnicos de enfermagem e de $42 \mathrm{~h}$ e mais nos Cursos de Auxiliares de Enfermagem.

Na ETECLA, verifica-se que o regime de trabalho do corpo docente, para ambos os cursos, oscila entre $12 \mathrm{~h}$ e $40 \mathrm{~h}$ semanais. Essa distribuição pode ser considerada como uma estratégia da ETECLA para equilibrar o custo/aluno, sem prejuízo da qualidade do ensino.

Segundo o documento: "Indicadores de Educação" 21, a eficiência do sistema escolar depende em grande parte da qualidade do corpo docente.

No estado do Rio Grande do Sul foi constatado, em 1973, com relação a qualificação do corpo docente que, aproximadamen 
te 478 não tinha habilitação necessária para o exercício de magistério no ensino de 18 grau e 408 para o ensino de 28 grau $^{21}$.

Comparando os resultados encontrados com a ETECLA, pode-se dizer que a referida escola apresenta uma situação satisfatória, considerando que seu corpo docente è constituído de profissionais com bom nível de qualificação, conforme se verifica na TABELA 21 .

\section{1 .10 - PRODUÇÃO DOS SERVIÇOS EDUCACIONAIS NA ETECLA}

Na produção dos serviços educacionais na ETECLA, além do número de matrículas na ūltima série, foram consideradas as seguintes variāveis:

- concluintes

- repetentes

- evadidos

Ainda, além dessas variáveis, considerou-se o custo/ aluno/ano, por ser um dos elementos de custo da unidade de ensino.

A ETECLA forneceu, para o presente estudo, o custo/ aluno/ano, em preços correntes, dos Cursos Técnicos de Enfermagem, nos sistemas regular e supletivo, e de Auxiliar de Enfermagem. No entanto, foi feito um deflacionamento 22,23 , segundo os indices a preços constantes, relativos ao ano de 1977, com vistas a permitir uma visão atual do custo/aluno/ano. Após, esse custo foi agrupado por períodos, conforme consta das tabe las 22,23 e 24 . 
a) Curso Técnico de Enfermagem

Quanto à produção, verifica-se na TABELA 22 , no período de 1966 a 1970 para o Curso Técnico de Enfermagem, no sistema regular, 97,38 de alunos concluintes e 2,78 de evadidos. No período de 1971 a 1975 houve 97,58 de concluintes, 1,78 de evadidos e, apenas 0,88 de repetentes.

Nos periodos referidos, pode-se dizer que o 8 de concluintes se manteve constante e acima de 908. Por outro lado, quanto aos repetentes e evadidos, os mesmos são. inexpressivos. Já no período de 1976 a 1977, embora apresente 92,98 de alunos concluintes, constata-se 7,18 de evadidos e ausência de repetentes.

Quanto ao custo/aluno/ano, nota-se uma tendênciacres cente, no período de 1966 a 1975. De 1976 a 1977, em que apenas dois anos são considerados, esse custo se apresenta um tanto elevado.

A média desse custo, calculada segundo os índices a preços constantes $(1977)^{22}, 23$, oscila de $\operatorname{Cr} \$ 7.449,32$ (sete mil quatrocentos e quarenta e nove cruzeiros e trinta e dois centavos) a $\operatorname{cr} \$ 11.536,31$ (onze mil quinhentos e trinta e seis cru zeiros e trinta e um centavos), no período de 1966 a 1977.

A TABELA 23, relativa ao Curso Técnico de Enfermagem, no sistema supletivo, apresenta, no periodo de 1974 a 1977, 93,68 de alunos concluintes, 1,68 de repetentes e 4,88 de alunos evadidos. Observa-se, ainda, no período referido, que o índice de alunos concluintes se manteve acima de $90 \%$.

Quanto ao custo/aluno/ano, observa-se que o mesmo se manteve constante, havendo, inclusive, uma tendência decrescen 
te de 1974 a 1977, ou seja, de Cr $\$ 15.608,64$ (quinze mil seiscentos e oito cruzeiros e sessenta e quatro centavos) para Cr $\$$ 15.100,00 (quinze mil e cem cruzeiros).

b) Curso de Auxiliar de Enfermagem

Verifica-se, na TABELA 24, no período de 1956 a 1977 , um aumento crescente do 8 de alunos concluintes, ou seja, de 69,78 para 94,78 ; com uma redução significativa tanto de alunos repetentes, como de evadidos, ou seja, de 2,58 para 1,18 e de 27,88 para 4,28 , respectivamente.

A média do custo/aluno/ano, a partir dos índices de deflacionamento $(1977)^{22,23}$, pode-se dizer que se manteve constan te, no período de 1956 a 1970. Já, para os demais períodos, a média de custo se apresenta crescente.

Segundo TOBELEM ${ }^{49}$, a escola é entendida como unidade de produção que utiliza fatores de produção, tais como professores, alunos e instalações físicas para oferecer serviços edu cacionais. Por outro lado, os estudos de custos tem que ser fundamentados e definidos, segundo os objetivos que se perseguem. No caso do Brasil, sabe-se que o objetivo maior è chegar a atender melhor ao crescimento da demanda e formação de recur sos humanos.

Convém dizer que se a educação implica custos, também implica benefícios. E, custo, em outras palavras, é apenas um lado da equação que liga "inputs" educacionais a "outputs" benefícios educacionais ${ }^{49}$. 
De acordo com o VI Encontro de Secretários de Educação e Representantes de Conselhos de Educação, "a anālise dos custos por aluno matriculado e por aluno aprovadoe uma das for mas de se verificar a produtividadedo sistema educacional." $37, i$

Partindo dessas fundamentações, observa-se que, embora a ETECLA apresente, um custo/aluno/ano, um tanto elevado, pode-se dizer que, a referida escola, apresenta uma adequada pro dutividade do seu sistema de ensino, tendo em vista o alto indice de alunos concluintes (aprovados) e os baixos percentuais de alunos repetentes e evadidos.

Outro aspecto é, com relação ao alto índice de fixação no mercado de trabalho, no Estado do Paraná, conforme se constata nas TABELAS 25 e 26 , ou seja, os egressos dos cursos da ETECLA são absorvidos, imediatamente, pelos serviços existentes no estado em referēncia.

Ainda, com relação ao aumento significativo do custo/ aluno/ano, na ETECLA, acredita-se que essa situação possa ser decorrente de diversos fatores, tais como:

- baixa relação professor/aluno, conforme jā foi cons tatado na TABELA 20;

- corpo docente constituido, na sua maioria, por enfermeiras com cursos a níveis de especialização e pós-graduação, portanto, com exigências de salários mais altos (TABELA 21), além de outros profes

i) MINISTERIO DA EDUCAÇÃo E CULTURA. Departamento de Ensino Médio. Apropriação de custos do ensino a nivel de 29 grau. Natal, 1974 . (Trabalho apresentado noVI Encontrode Secretários de Educação e Representantes de Conselhos de Educação, realizado em Natal, de 11 a 15 de fevereiro de 1974. p.18 
- sores, para a parte de educação geral, onerando, provavelmente, o custo do ensino.

- aquisição de novos equipamentos e ampliação das ins talações, segundo a Direção da ETECLA;

- custo de administração (salário do pessoal adminis trativo, manutenção e instalações)

- melhoria de condições materiais em função do alu彑 no 
TABELA 22

Matriculas, Alunos Concluintes, Repetentes, Evadidos, Total e Média do Custo/

Aluno/Ano, a Preços Correntes e Constantes, do Curso Técnico de Enfermagem, no Sistema Regular, na ETECLA, no período de 1966 a 1977

\begin{tabular}{|c|c|c|c|c|c|c|c|c|c|c|c|}
\hline \multirow{3}{*}{ PERIODO } & \multicolumn{7}{|c|}{ C U R S O } & \multicolumn{4}{|c|}{$E N F E R M A G M$} \\
\hline & \multirow{2}{*}{$\underset{\star}{\operatorname{Matriculas}}$} & \multicolumn{2}{|c|}{ Concluintes } & \multicolumn{2}{|c|}{ Repetentes } & \multicolumn{2}{|c|}{ Evadidos } & \multirow{2}{*}{$\begin{array}{l}\text { Total (I) } \\
\text { do Custo/ } \\
\text { Aluno/Ano }\end{array}$} & \multirow{2}{*}{$\begin{array}{l}\text { Média (1) } \\
\text { do Custo/ } \\
\text { Aluno/Ano }\end{array}$} & \multirow{2}{*}{$\begin{array}{l}\text { Total (2) } \\
\text { do Custo/ } \\
\text { Aluno/Ano }\end{array}$} & \multirow{2}{*}{$\begin{array}{l}\text { Média (2) } \\
\text { do Custo/ } \\
\text { Aluno/Ano }\end{array}$} \\
\hline & & No & 8 & N8 & 8 & No & 8 & & & & \\
\hline $1966-1970$ & 37 & 36 & 97,3 & - & - & 1 & 2,7 & $4.595,29$ & 919,05 & $37.246,60$ & $7.449,32$ \\
\hline $1971-1975$ & 118 & 115 & 97,5 & 1 & 0,8 & 2 & 1,7 & $19.434,09$ & $3.886,81$ & $56.578,68$ & $11.315,73$ \\
\hline $1976-1977$ & 71 & 66 & 92,9 & - & - & 5 & 7,1 & $19.548,49$ & $9.774,24$ & $23.072,62$ & $11.536,31$ \\
\hline TOTAL & 226 & 217 & 96,0 & 1 & 0,4 & 8 & 3,6 & $43.577,87$ & $3.631,48$ & $116.897,90$ & $9.741,49$ \\
\hline
\end{tabular}

Fonte: ETECLA - 1978 preços constantes, relativos ao ano de 1977 .

(2) Total e média do custo/aluno/ano a

(*) Na última série. 


\section{TABELA 23}

Matriculas, Alunos Concluintes, Repetentes, Evadidos, Total e Média do Custo/Aluno/ Ano, a Preços Correntes e Constantes, do Curso Técnico de Enfermagem, no Sistema Supletivo, na ETECLA, nos anos de 1974 a 1977

\begin{tabular}{|c|c|c|c|c|c|c|c|c|c|}
\hline \multirow{3}{*}{ ANOS } & \multicolumn{3}{|c|}{ C U R S O } & EC & c 0 & \multicolumn{3}{|c|}{$E N F E R M A G E M$} & \multirow{3}{*}{$\begin{array}{l}\text { Total (2) } \\
\text { do Custo/ } \\
\text { Aluno/Ano }\end{array}$} \\
\hline & \multirow{2}{*}{$\underset{\star}{\operatorname{Matriculas}}$} & \multicolumn{2}{|c|}{ Concluintes } & \multicolumn{2}{|c|}{ Repetentes } & \multicolumn{2}{|c|}{ Evadidos } & \multirow{2}{*}{$\begin{array}{l}\text { Total (1) } \\
\text { do Custo/ } \\
\text { Aluno/Ano }\end{array}$} & \\
\hline & & NQ & 8 & No & 8 & NQ & 8 & & \\
\hline 1974 & 27 & 26 & 96,3 & 1 & 3,7 & - & - & $6.061,61$ & $15.608,64$ \\
\hline 1975 & 35 & 33 & 94,3 & - & - & 2 & 5,7 & $8.020,86$ & $16.172,56$ \\
\hline 1976 & 22 & 21 & 95,5 & - & - & 1 & 4,5 & $10.948,37$ & $15.626,07$ \\
\hline 1977 & 42 & 38 & 90,5 & 1 & 2,4 & 3 & 7,1 & $15.100,00$ & $15.100,00$ \\
\hline TOTAL & 126 & 118 & 93,6 & 2 & 1,6 & 6 & 4,8 & $40.130,84$ & $62.507,27$ \\
\hline
\end{tabular}

Fonte: ETECLA - 1978

(1) Total do custo/aluno/ano a preços correntes (2) Total do custo/aluno/ano a preços constan tes, relativos ao ano de 1977 . (*) No último período. 
TABELA 24

Número Total de Mátriculas, Alunos Concluintes, Repetentes, Evadidos, Total e Média do Custo/Aluno/Ano, a Preços Correntes e Constantes, do Cursode Auxiliar de Enfermagem, na ETECLA, no período de 1956 a 1977

\begin{tabular}{|c|c|c|c|c|c|c|c|c|c|c|c|}
\hline \multirow{3}{*}{ PERIODO } & \multicolumn{3}{|c|}{$C \cup R S O$} & \multicolumn{4}{|c|}{$A U X I L I A R$} & \multicolumn{3}{|c|}{$D E \quad E N F E R M A G E M$} & \\
\hline & \multirow{2}{*}{$\begin{array}{l}\text { No total } \\
\text { de Matrí } \\
\text { culas }\end{array}$} & \multicolumn{2}{|c|}{ Concluintes } & \multicolumn{2}{|c|}{ Repetentes } & \multicolumn{2}{|c|}{ Evadidos } & \multirow{2}{*}{$\begin{array}{l}\text { Total (1) } \\
\text { do Custo/ } \\
\text { Aluno/Ano }\end{array}$} & \multirow{2}{*}{$\begin{array}{l}\text { Média (1) } \\
\text { do Custo/ } \\
\text { Aluno/Ano }\end{array}$} & \multirow{2}{*}{$\begin{array}{l}\text { Total (2) } \\
\text { do Custo/ } \\
\text { Aluno/Ano }\end{array}$} & \multirow{2}{*}{$\begin{array}{l}\text { Média (2) } \\
\text { do Custo/ } \\
\text { Aluno/Ano }\end{array}$} \\
\hline & & N8 & 8 & No & 8 & N8 & 8 & & & & \\
\hline $1956-1960$ & 277 & 193 & 69,7 & 7 & 2,5 & 77 & 27,8 & 150,33 & 30,06 & $42.814,32$ & $8.562,86$ \\
\hline $1961-1965$ & 261 & 193 & 73,9 & 5 & 1,9 & 63 & 24,2 & 980,88 & 196,17 & $37.173,27$ & 7.434 .65 \\
\hline $1966-1970$ & 306 & 273 & 89,2 & 6 & 2,0 & 27 & 8,8 & $4.595,29$ & 919,05 & $37.246,60$ & 7.449 .32 \\
\hline $1971-1975$ & 447 & 398 & 89,0 & 9 & 2,0 & 40 & 9,0 & $19.434,45$ & $3.886,89$ & $56.579,61$ & $11.315,92$ \\
\hline $1976-1977$ & 95 & 90 & 94,7 & 1 & 1,1 & 4 & 4,2 & $19.548,49$ & $9.774,24$ & $23.072,62$ & $11.536,31$ \\
\hline TOTAL & 1.386 & 1.147 & 82,7 & 28 & 2,1 & 211 & 15,2 & $44.709,44$ & $2.032,24$ & $196.886,42$ & $8.949,38$ \\
\hline
\end{tabular}

Fonte: ETECLA - 1978

(1) Total e média do custo/aluno/ano a preços correntes

(2) Total e média do custo/aluno/ano a preços constantes, relativos ao ano de 1977 . 


\section{1 .11 - ÍNDICE DE FIXAÇÃO NO MERCADO DE TRABALHO}

Neste item, o levantamento limita-se, apenas, ao ano de 1977, por não possuir, a ETECLA, informações completas necessárias à elaboração de uma série histórica.

a) Segundo o Setor

\section{TABELA 25}

Distribuição dos Técnicos e Auxiliares de Enfermagem formados pela ETECLA, em atividade ou não, segundo o setor de trabalho-

1977

\begin{tabular}{l|c|c|c|c}
\hline \multirow{2}{*}{ SETOR } & \multicolumn{2}{|c|}{ TEC. DE ENFERMAGEM } & \multicolumn{2}{c}{ AUX. DE ENFERMAGEM } \\
\cline { 2 - 5 } & No & 8 & NQ & 8 \\
\hline $\begin{array}{l}\text { Hospital } \\
\text { Escola }\end{array}$ & 50 & 67,6 & 29 & 60,4 \\
$\begin{array}{l}\text { Saúde Pública } \\
\text { Consultório } \\
\text { especializado }\end{array}$ & 5 & 6,8 & - & - \\
$\begin{array}{l}\text { Previdência } \\
\text { Social }\end{array}$ & 1 & 8,1 & 5 & 10,5 \\
(1) Outros & 1 & 1,3 & 6 & 12,5 \\
Não trabalham & 5 & 8,1 & 2 & 4,1 \\
\hline & 6 & 6,8 & 6 & 12,5 \\
\hline
\end{tabular}

Fonte: ETECLA - 1978

(1) Indústria, Obras Sociais 
Observa-se, na TABELA 25, que, dos 74 técnicos de enfermagem formados pela ETECLA em 1977, 93,28 fixaram-se no mercado de trabalho. Destes, 67,68 trabalham em hospitais, 8,18 em saúde pública e apenas 1,38 na Previdência Social.

Nota-se que o maior percentual se encontra em hospitais. Esse fato è devido, em parte, ao tipo de formação recebida, uma vez que a maior absorção de pessoal de enfermagem desse nível se dá em hospitais. Observa-se, ainda, que o técnico de enfermagem participa, como auxiliar de ensino, em curso de auxiliar de enfermagem e de habilitação bāsica em saúde, num percentual de 6,88 . O restante fica dividido em outros serviços. Aparecem, também, aqueles que não trabalham $(6,88)$ por motivos diversos, tais como: casamento, licença por doença, in gresso na vida religiosa e prosseguimento de estudos. A Direção da ETECLA informa, no entanto, que a maioria desses motivos é temporário.

Com relação aos 48 auxiliares de enfermagem formados pela ETECLA em 1977, ainda, observa-se, na TABELA 25, que 87,58 fixaram-se no mercado de trabalho. Destes, 60,48 trabalham em hospitais e 10,58 em saúde pública. O restante fica dividido em outros serviços.

Aparecem, ainda, aqueles que não trabalham por motivos semelhantes aos já mencionados para os Técnicos de Enferma gem.

Verifica-se, também, que o maior percentual se dá em hospitais. Isso é consequência, do tipo de formação recebida, e, em parte, do tipo de mercado, já que são os hospitais que ab sorvem maior contingente de pessoal auxiliar de enfermagem. 
b) Segundo os Estados

\section{TABELA 26}

Fixação do Técnicoe Auxiliar de Enfermagem no Mercado de Trabalho, segundo os

Estados - 1977

\begin{tabular}{l|c|c|c|c}
\hline & \multicolumn{2}{|c|}{$\begin{array}{c}\text { Técnico de } \\
\text { Enfermagem }\end{array}$} & \multicolumn{2}{c}{$\begin{array}{c}\text { Auxiliar de } \\
\text { Enfermagem }\end{array}$} \\
\cline { 2 - 5 } & N\& & 8 & No & 8 \\
\hline Paraná & 50 & 67,6 & 35 & 72,9 \\
São Paulo & 1 & 1,3 & - & - \\
Sta. Catarina & 6 & 8,1 & 4 & 8,3 \\
R.G. do Sul & 3 & 4,0 & 1 & 2,1 \\
Minas Gerais & 2 & 2,8 & 1 & 2,1 \\
Rio de Janeiro & 1 & 1,3 & 1 & 2,1 \\
(1) Outros & 6 & 8,1 & - & - \\
Não Trabalham & 5 & 6,8 & 6 & 12,5 \\
\hline
\end{tabular}

Fonte: ETECLA - 1978

(1) Amapā, Rondônia, Alemanha, Paraguai e Espirito Santo

Verifica-se, na TABELA 26, que a grande maioria dos formados pela ETECLA, em 1977, fixou-se no Estado do Paraná, ou seja, 67,68 dos técnicos e 72,98 dos auxiliares de enfermagem fixaram-se no mercado de trabalho parananense. Pode-se dizer que é um indice satisfatório, uma vez que mais de 678 dos concluintes de curso foram absorvidos pelo mercado de trabalho estadual. 
Segundo o Relatório de Avaliação do Projeto - FormaÇão de Auxiliar de Enfermagem do Ministério da Saúde ${ }^{4}$, verifica-se, em 1972, que em 11 Estados da Federação e em 1 Território, dos 155 técnicos de enfermagem e dos 9.442 auxiliares de enfermagem, 96,78 dos técnicos e 95,38 dos auxiliares fixaramse em hospitais, e apenas 3,38 dos técnicos e 4,78 dos auxilia res de enfermagem fixaram-se em saúde püblica.

Comparando esses dados com os encontrados no Estado do Paranā, em 1977, verifica-se uma situação similar, ou seja, 67,68 de técnicos e 60,48 de auxiliares de enfermagem estão atuando em hospitais. Observa-se, no entanto, que no Estado do Paranā a fixação em hospitais ocorre em grande percentual, mas ainda há uma distribuição maior na área de saúde pública, isto é, 8,18 e 10,58 para o técnico e auxiliar de enfermagem, respectivamente.

E provável que em 1977, nos 11 Estados da Federação e no Território referidos, tenha ocorrido mudanças com relação à colocação desse pessoal de enfermagem no mercado de trabalho em outros setores, face aos novos estímulos de programas de atendimento às populações.

\subsubsection{2 - PROSSEgUIMENTO DE ESTUdOS A NİVEL SUPERIOR}

Neste item o levantamento limita-se apenas ao ano de 1977, por não possuir, a ETECLA, informações completas, necessārias à elaboração de uma série histórica. 


\title{
TABELA 27
}

\begin{abstract}
Prosseguimento de Estudos a Nivel Superior do Técnico e do Auxiliar de Enfermagem, formados na ETECLA, 1977.
\end{abstract}

\begin{tabular}{l|c|c|c|c|c}
\hline \multicolumn{1}{l|}{$\begin{array}{l}\text { TECNICO DE } \\
\text { ENFERMAGEM }\end{array}$} & \multicolumn{2}{|c|}{$\begin{array}{c}\text { AUXILIAR DE } \\
\text { ENFERMAGEM }\end{array}$} & \multicolumn{2}{|c|}{$\begin{array}{c}\text { 8 DE PROSSEGUIMENTO DE } \\
\text { ESTUDOS A NIVEL SUPERIOR }\end{array}$} \\
\hline Formados & $\begin{array}{l}\text { Prosse } \\
\text { guiram }\end{array}$ & Formados & $\begin{array}{c}\text { Prosse } \\
\text { guiram }\end{array}$ & $\begin{array}{c}\text { Do Técnico } \\
\text { ge Enfermagem }\end{array}$ & $\begin{array}{c}\text { Do Auxiliar } \\
\text { de Enfermagem }\end{array}$ \\
\hline 74 & 10 & 48 & - & 13,5 & - \\
\hline
\end{tabular}

Fonte: ETECLA - 1978 .

Observa-se, na tabela 27, que, dos 74 técnicos de enfermagem formados em 1977, 10 prosseguiram estudos de nível su perior, ou seja, 13,58. Destes, segundo a Direção da ETECLA apenas 1 optou pela Enfermagem. No entanto, é interessante ressaltar que, embora 13,58 tenham prosseguido seus estudos, esse contingente não deixou de exercer a profissão. Com relação ao auxiliar de enfermagem, verifica-se que, dos 48 formados, nenhum prosseguiu seus estudos.

Segundo oguIsso ${ }^{42}$, o concluinte de curso de 18 grau poderá fazer cursos de qualificação profissional, cujo currícu lo é composto apenas de disciplinas profissionalizantes e é conferido Certificado de Auxiliar de Enfermagem, com validade nacional, mas sem direito a prosseguimento de estudos em nivel superior. Por outro lado, há, ainda, a possibilidade deles pres tarem exame supletivo de Técnico de Enfermagem, recebendo, nes se caso, Certificado de Técnico e não diploma. Entretanto, não 
podem prosseguir estudos em nível superior, por não terem concluído o 29 grau, embora possam exercer a ocupação como Técnico de Enfermagem.

Jā o Técnico de Enfermagem, com sua formação completa de educação geral e profissionalizante de enfermagem, possui o direito de prosseguimento de estudos em nível superior.

Na ETECLA, verifica-se que hã prosseguimento de estudos somente para o técnico de enfermagem.

Pode-se atribuir esse fato à facilidade com que o técnico de enfermagem ingressa no 39 grau, face aos pré-requisitos que possui.

Para os auxiliares de enfermagem, não hã prosseguimento de estudos em nível superior pelos motivos já referidos.

\section{2 - situação e necessidade de pessoal de ENFERMAGEM NO ESTADO DO PARANÁ}

A escassez do pessoal de saúde em todas as categorias é um dos problemas defrontados no Estado do Paranā, como nos demais estados da Região Sul. Quanto à Enfermagem, os recursos humanos são ainda insuficientes para atender às necessidades de saūde, tanto nas áreas hospitalar e para-hospitalar, como na de saúde pública.

Os recursos humanos de enfermagem estão representados pela enfermeira, pelo técnico de enfermagem e pelo pessoal auxiliar de enfermagem: auxiliar de enfermagem, visitadora sanitária, instrumentador cirúrgico e atendente. 
A deficiēncia crítica de enfermeiras tem sido um fator imperativo na utilização do pessoal auxiliar de enfermagem nos serviços de saúde. Por outro lado, reconhece-se que esse pessoal, quando adequadamente preparado e supervisionado, pres ta uma valiosa contribuição na prestação das ações de saūde ${ }^{2}$.

A primeira parte deste estudo abrange o levantamento quanto à disponibilidade de recursos humanos de enfermagem: enfermeira, técnico de enfermagem, auxiliar de enfermagem e atendente. A segunda, refere-se ao levantamento quanto à neces sidade de enfermeira, técnico de enfermagem e auxiliar de enfermagem. Ambas abrangeram as organizações hospitalares, parahospitalares e os serviços oficiais de saúde pública. 
4.2.1 - NÚMERO DISPONÍVEL E NECESSÁRIO DE RECURSOS HUMANOS DE ENFERMAGEM Ȧ ASSISTÉNCIA HOSPITALAR

\section{TABELA 28}

Recursos Humanos de Enfermagem destinados à Assistência Hospitalar, no Estado do Paranā - 1974

\begin{tabular}{l|c|c}
\hline \multirow{2}{*}{$\begin{array}{c}\text { CATEGORIA } \\
\text { DE } \\
\text { PESSOAL }\end{array}$} & \multicolumn{2}{|c}{$\begin{array}{r}\text { RECURSOS HUMANOS DISPONIVEIS A } \\
\text { ASSISTENCIA HOSPITALAR }\end{array}$} \\
\cline { 2 - 3 } Enfermeira & Número & Razão/100 leitos \\
Técnico de Enfermagem & (1) 56 & 0,9 \\
Auxiliar de Enfermagem & 990 & 3,8 \\
Atendente & (2) 5.100 & 19,8 \\
\hline T O T A L & 6.374 & 24,8 \\
\hline
\end{tabular}

Fonte: Anuário Estatístico do Brasil da Fundação Instituto Bra sileiro de Geografia e Estatística - 1976 (dados de 1974) Número de leitos: 25.625 - Anuārio Estatístico do Brasil da FIBGE - 1976 (dados de 1974)

(1) ABEn/Seção do Paranā (dados de 1973) (2) Estão incluídos além de atendentes, parteiras práticas e práticos de enfermagem.

Verifica-se, na TABELA 28, que o Estado do Paraná se apresenta em 1974 com 228 enfermeiras; 56 técnicos de enferma= gem; 990 auxiliares de enfermagem e 5.100 atendentes, ou seja, 0,9 enfermeiras, 0,2 técnicos de enfermagem, 3,8 auxiliares de enfermagem e 19,8 atendentes/100 leitos. 
Considerando os recursos humanos disponíveis de enfermagem e sua razão/100 leitos, no Estado do Paraná, em 1974, e comparando-os com o número e a razão/100 leitos necessários, segundo o Padrão estabelecido pela OPS/OMS e a razão convencio nada pela autora, constata-se um deficit muito significativo, ou seja, da ordem de 1.313 enfermeiras; 2.513 técnicos de enfermagem e de 3.378 auxiliares de enfermagem, o que deve merecer atenção especial dos setores de saúde e de educação. (TABELA 29).

\subsection{2 - NÚMERO disPONÍVEL E NECESSÁRIO DE RECURSOS HUMANOS DE ENFERMAGEM NOS SERVIÇOS DE SAÚ- DE PÚBLICA E ESTABELECIMENTOS PARA-HOSPI- TALARES}

\section{TABELA 30}

Recursos Humanos de Enfermagem Destinados aos Serviços de Saūde Pública e Estabelecimentos Para-Hospitalares, no Estado do Paranā - 1974

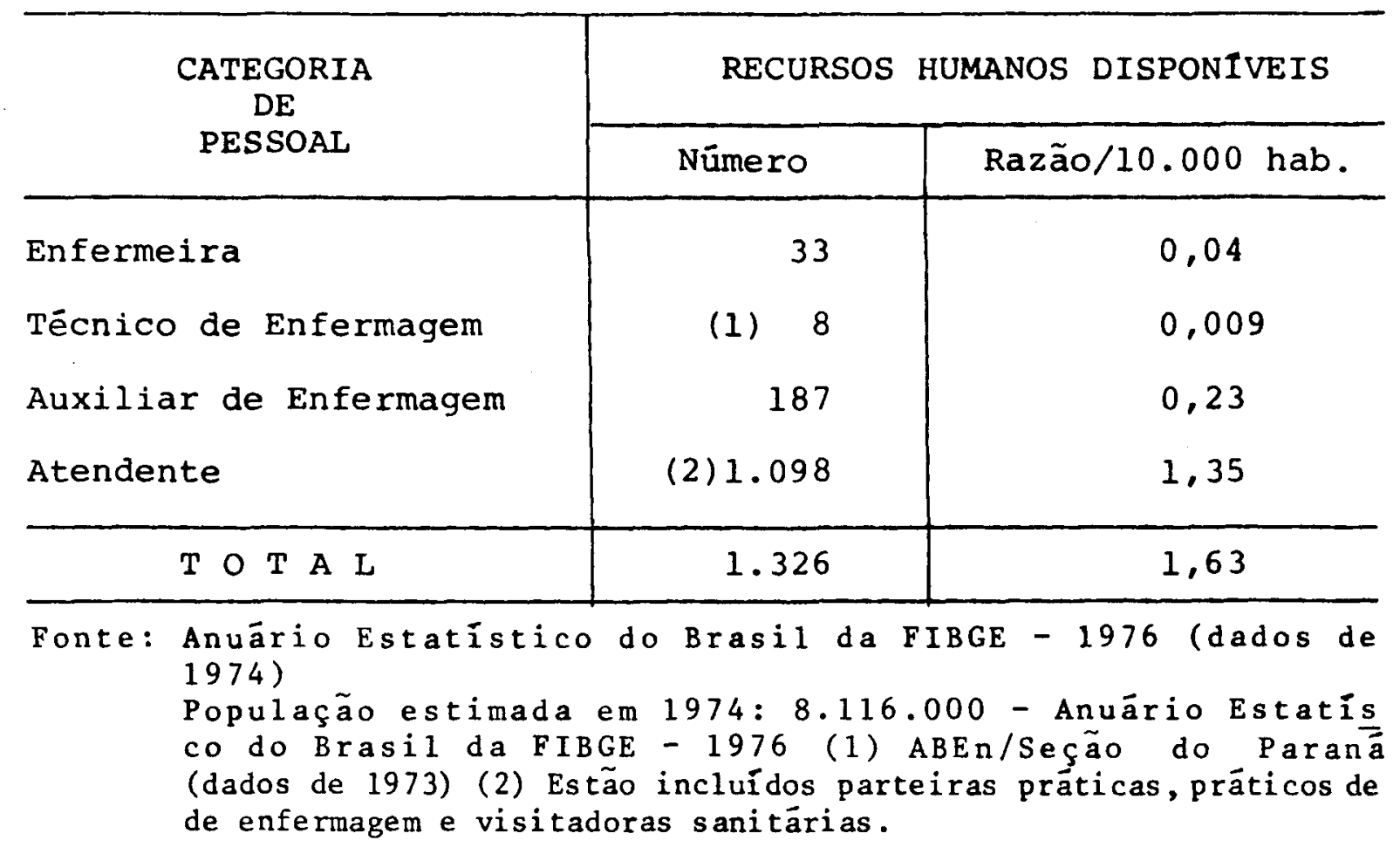


Verifica-se, na TABELA 30, que o Estado do Paranā se apresenta em 1974 com 33 enfermeiras, 8 técnicos de enfermagem 187 auxiliares de enfermagem e 1.098 atendentes, ou seja, 0,04 enfermeiras, 0,009 técnicos de enfermagem, 0,23 auxiliares de enfermagem e 1,35 atendentes/10.000 habitantes.

TABELA 31

Disponibilidade e Necessidade de Recursos Humanos de Enfermagem para a Assistēncia em Serviços de Saūde Pūblica e Estabelecimentos Para-Hospitalares, no Estado do Paranā - 1974



Considerando os recursos humanos disponíveis de enfermagem e sua razão/10.000 habitantes, no Estádo do Paraná em 1974, e, comparando-os com o nümero e razão/10.000 habitantes necessārios, segundo o Padrão proposto pela OPS/OMS, no Plano 
Decenal de Saúde para as Américas ${ }^{4}$, constata-se um acentuado de ficit, ou seja, da ordem de 1.184 enfermeiras, 2.426 técnicos de enfermagem e 11.581 auxiliares de enfermagem. (TABELA 31)

De acordo com o Relatório de Avaliação - Formação de Auxiliar de Enfermagem, "o contingente de pessoal de enfermagem em atividade no País, em 1970, atinge a 77.732, com a seguinte estrutura ocupacional:

Categoria

Enfermeiro $\ldots \ldots \ldots \ldots \ldots$

Tëcnico de Enfermagem ..........

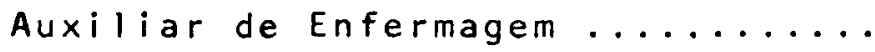

Atendente (inclusive prático de enfermagem e parteira prätica) .....

Soma $\ldots \ldots \ldots \ldots \ldots$
N?

8.500

19.000

49.955

77.732
$\%$

11,0

0,4 24,4

64,2 100,0

Observa-se que a estrutura ocupacional da enfermagem está quase que inteiramente tomada pelo pessoal auxiliar, destacando-se o Atendente com mais de $60 \%$ e representando o enfer meiro cerca de $11,0 \%$ do total. $1141, \mathrm{j}$

Comparando com os dados encontrados no Estado do Paraná, observa-se uma situação idêntica, ou seja, um deficit muị to acentuado de recursos humanos de enfermagem habilitados, tan to em serviços hospitalares e para-hospitalares, como nos serviços de saúde püblica. Apresenta-se, também, com um grande con tingente de atendente-pessoal de nível elementar.

j) MINISTÉRIO DA SAODE. Divisão Nacional de Organização Sanitária. Setor de Enfermagem. Guia para curso supletivo de auxiliar de enfermagem. Rio de Janeiro, 1975. p.35 
As dificuldades a serem superadas com a qualificação do vultoso contingente de Auxiliares de Enfermagem, sugerem que ainda por certo período de tempo, os quadros de pessoal auxiliar continuarão a ser preenchidos por Atendentes de Enfermagem.

Ressalta-se, ainda, que o número inexpressivo de técnicos de enfermagem no Estado do Paraná, deve-se ao fato de terem ingressado no mercado de trabalho a partir de 1969.

\section{3 - PROJEÇÃO DE NECESSIDADES DE RECURSOS HUMANOS DE ENFERMAGEM NO ESTADO DO PARANÁ, EM 1980}

\section{3 .1 - ASSISTÊNCIA HOSPITALAR}

o critério adotado para calcular a projeção de neces sidades de pessoal de enfermagem em Assistência Hospitalar em 1980 foi o proposto pela OPS/OMS, ou seja, 33 elementos de enfermagem, sendo 6 enfermeiras para 100 leitos. ${ }^{43}$ 


\section{TABELA 32}

Projeção de Necessidades de Recursos Humanos de Enfermagem, para Assistência Hospitalar, no Estado do Paranā, em 1980

\begin{tabular}{|c|c|c|c|c|c|}
\hline \multirow{3}{*}{$\begin{array}{c}\text { CATEGORIA } \\
\text { DE } \\
\text { PESSOAL }\end{array}$} & \multicolumn{4}{|c|}{ RECURSOS HUMANOS DE ENFERMAGEM } & \multirow{3}{*}{$\begin{array}{l}\text { PROJEÇÃO } \\
\text { DE } \\
\text { NECESSIDADES } \\
\text { (N\&) }\end{array}$} \\
\hline & \multicolumn{2}{|c|}{$\begin{array}{c}\text { Disponivel } \\
1974\end{array}$} & \multicolumn{2}{|c|}{$\begin{array}{l}\text { Necessário(1) } \\
\text { em } 1980\end{array}$} & \\
\hline & N8 & $\begin{array}{c}\text { Razão/ } \\
100 \text { leitos }\end{array}$ & NQ & $\begin{array}{c}\text { Razão/ } \\
100 \text { leitos }\end{array}$ & \\
\hline Enfermeira & 228 & 0,67 & 2.012 & 6 & 1.784 \\
\hline Técnico de & & & & & \\
\hline Enfermagem & (2) 56 & 0,16 & 3.354 & (3) 10 & 3.298 \\
\hline Auxiliar de & & & & & \\
\hline Enfermagem & 990 & 2,95 & 5.703 & (3) 17 & 4.713 \\
\hline $\mathrm{T} O \mathrm{TAL}$ & 1.274 & 3,79 & 11.070 & 33 & 9.796 \\
\hline \multicolumn{6}{|c|}{ Fonte: $\begin{aligned} \text { Anuário } \\
1974)\end{aligned}$} \\
\hline \multicolumn{6}{|c|}{ 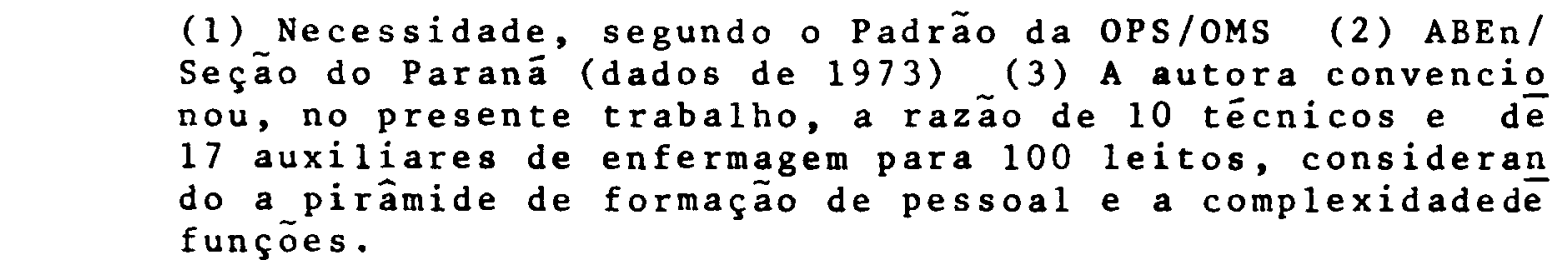 } \\
\hline
\end{tabular}

Constata-se, pela TABELA 32, a necessidade, em 1980, de 1.784 enfermeiras; 3.298 técnicos de enfermagem e 4.713 auxiliares de enfermagem, para os $33.548^{k}$ leitos projetados para o ano em referência.

k) A projeção de leitos para 1980 , no valor de 33.548 , foi feita através do índice de $9,52 \%$ de aumento ao ano, conforme o adotado, para estimativa, no documento da Federação Brasileira de Hospitais, junho de 1973. 


\subsection{2 - SERVigOS DE SAúde pública e estabele- CIMENTOS PARA-HOSPITALARES}

Para o cálculo da projeção das necessidades de recursos humanos de enfermagem em serviços dessa natureza, em 1980 , utilizou-se o Padrão proposto pela OPS/OMS, ou seja, 19.0 elementos de enfermagem para 10.000 habitantes, sendo deste, 4.5 enfermeiras, dos quais $1 / 3$ é constituído de enfermeiras e $2 / 3$ de técnicos de enfermagem, além de 14.5 de auxiliares de enfermagem. ${ }^{42}, 43,3$

Constata-se, na TABELA 33, no Estado do Paranā, em 1980, a necessidade de 1.508 enfermeiras; 3.074 técnicos de enfermagem e 14.710 auxiliares de enfermagem, para uma população de $10.274 .200 .^{\ell}$

De acordo com o Relatório de Avaliação-Formação de Auxiliares de Enfermagem do Ministério da Saūde ${ }^{41}$, em 1980, o País contará com aproximadamente 16.000 graduados em Enfermagem, mantidas as atuais tendências da formação e da evasão. E ressal tado que o estoque estará muito aquém das necessidades previstas pelo Plano Decenal de Saúde para as Américas, que indica proporção de 4.5 enfermeiras para 10.000 habitantes. Corresponde, em números absolutos, a 56.250 enfermeiros.

Segundo OGUISSO ${ }^{2}$, se for considerada a proporção de $1 / 3$ de pessoal de nível superior e $2 / 3$ de nível médio, istoé, de técnicos de enfermagem, haverá necessidade de 18.750 enfermeiros e 37.500 técnicos de enfermagem.

l) População estimada, segundo O Anuário Estatístico do Brasil da FIBGE - 1976 
Com relação ao Auxiliar de Enfermagem, observa-se, ain da, no Relatório do Ministério da Saúde ${ }^{41}$, que a situação da me ta esperada para 1980, consoante as proposições do Plano Decenal de Saūde, será de 14.5 por 10.000 habitantes, o que equivale a 181.000 auxiliares de enfermagem. Os estoques conhecidos atualmente, acrescidos, segundo hipóteses alternativas, dos flu xos de preparação e de evasão, faz prever que, no final da década, o pessoal desta categoria profissional somará aproximadamente 60.000 , ou seja, cerca de 4.8 por 10.000 habitantes. Para atingir a meta proposta, hã de capacitar, até o final da década, aproximadamente, 130.000 auxiliares de enfermagem.

o Ministério da Saūde demonstrando sua visível preocupação com a problemātica da enfermagem nacional e procurando cumprir as Recomendações do Plano Decenal, vem promovendo estudos e programas para apoiar e fortalecer os sistemas de formação e capacitação de auxiliares de enfermagem necessārios à demanda, no país, na década atual.

Na projeção de necessidades de recursos humanos de en fermagem, em 1980, no Estado do Paraná, observa-se uma situação similar da encontrada no referido relatório, ou seja, no ano em referência, haverá ainda um acentuado deficit desses recursos, o que merece atenção especial dos setores de educação e saúde. 
4.4 - Situaç̃̃o DA CAPACIDAdE DO APARELHO FORMADOR DO ENSINO DE ENFERMAGEM A NÍVEL DE 2- GRAU NO ESTADO DO PARANÁ

o aparelho formador de recursos humanos de enfermagem, a nível de 28 grau, no Estado do Paranā, em 1977, compreen de :

- oito Cursos de Técnico de Enfermagem, sendo cinco no Sistema Regular e três no Sistema Supletivo, lo lizados em:

- Curitiba : 2

- Londrina : 5

- Jacarezinho : 1

- quinze Cursos de Auxiliares de Enfermagem, sendo nove no Sistema Regular e seis no Sistema Supletivo, localizados em:

- Curitiba : 5

- Londrina : 4

- Maringá : 1

- Apucarana: 2

- Cascavel : 1

- Guarapuava: 1

- Paranavaí: 1

Verifica-se, na TABELA 34, que o Estado do Paranā, em 1977, apresenta uma capacidade de formação de pessoal de enferma gem, a nível técnico e auxiliar, da seguinte ordem:

- Técnico de Enfermagem

- No Sistema Regular: 257

- No Sistema Supletivo: 201 
- Auxiliar de Enfermagem,

No Sistema Regular : 620

No Sistema Supletivo: 188

Constata-se que as Escolas e/ou Cursos de Técnico de Enfermagem e de Auxiliar de Enfermagem, no Estado do Paraná, em 1977, participaram na formação de:

- 458 técnicos de enfermagem

- 808 auxiliares de enfermagem

\section{TABELA 34}

Produção dos Cursos de Técnico de Enfermagem e de Auxiliar de Enfermagem, nos Sistemas Regular e Supletivo, no Estado do Paraná - 1977

\begin{tabular}{l|c|c|c|c}
\hline \multirow{2}{*}{ MUNICIPIOS } & \multicolumn{2}{|c|}{ TECNICO DE ENFERMAGEM } & \multicolumn{2}{|c}{ AUXILIAR DE ENFERMAGEM } \\
\cline { 2 - 5 } & $\begin{array}{c}\text { Sistema } \\
\text { Regular }\end{array}$ & $\begin{array}{c}\text { Sistema } \\
\text { Supletivo }\end{array}$ & $\begin{array}{c}\text { Sistema } \\
\text { Regular }\end{array}$ & $\begin{array}{c}\text { Sistema } \\
\text { Supletivo }\end{array}$ \\
\hline Curitiba & 160 & 79 & 85 & 130 \\
Londrina & 79 & 122 & 52 & 58 \\
Jacarezinho & 18 & - & - & - \\
Maringá & - & - & 32 & - \\
Paranavaí & - & - & 126 & - \\
Apucarana & - & - & 58 & 188 \\
Cascavel & - & 201 & 620 & - \\
Guarapuava & - & - & & - \\
\hline T O T A I & 257 & - & - & - \\
\hline
\end{tabular}


Segundo o Relatório de Avaliação do Projeto - Formação de Auxiliar de Enfermagem, do Ministério da Saúde ${ }^{41}$, a produção dos cursos de auxiliares de enfermagem no País, no período de 31 anos (1941-1972) era da ordem de 23.398 auxiliares. Em 1968 foram formados os primeiros técnicos em enfermagem. No de curso de 5 anos $(1968 / 1972)$ foram produzidos 385 técnicos de en fermagem. Observa-se, no entanto, um número insuficiente para atender às necessidades do mercado de trabalho. Decorre daí a utilização, pelos serviços de saúde, quer do setor público ou privado, do elemento atendente, que em 1970 era da ordem de 69.841 no País.

Considerando a projeção de necessidades no Estado do Paraná verificada nos itens 4.2 e 4.3 , infere-se que, as escolas ainda não estão formando, em número suficiente, pessoal de enfermagem a nível técnico e auxiliar, para atender as expecta tivas do mercado de trabalho atual e de 1980 .

4.5 - CRITÉrios para SELEç̃̃o de MUNicípios, NO ESTADO DO PARANÁ, ONDE PODERIAM SER IMPLANTADOS OS CURSOS DE TÉCNICO E DE AUXILIAR DE ENFERMAGEM

Neste item serā apresentada, inicialmente, uma abordagem sobre os critérios para a seleção de municípios, do Estado do Paraná, onde poderiam ser implantados Cursos de Técnicos e de Auxiliar de Enfermagem. A seguir, tentar-se-á demonstrar quais as localidades do Estado em referência que estariam capacitadas para a implantação desses cursos, a curto e médio prazos. 
A formação do pessoal de enfermagem a níveis de técnico e de auxiliar, na maioria das vezes, não pode ser realizada em municípios onde ela é mais necessária, em virtude de eles não apresentarem condições mínimas de formar essas categorias ocupacionais. Isso ocorre com menor freqtência em centros maiores ${ }^{14}$.

Para que possa funcionar o ensino de enfermagem como habilitação ou como qualificação no Estado do Paraná, foram adotados, pela autora critérios para a instalação desses cur$\operatorname{sos}^{14}$, com o intuito de garantir a qualidade do produto final dos mesmos e a maior eficiência no atendimento às necessidades de saúde da população a saber:

- MUNICIPIOS COM MAIS DE 30.000 HABITANTES, devendo merecer prioridade, inicialmente, aqueles considerados pólos de desenvolvimento.

- MUNICIPIOS COM UM OU MAIS hOSPITAIS QUE, em sua totalidade, TENHAM MAIS DE 100 LEITOS e que apresentem condições minimas exigidas para o ensino de enfermagem ou que possam vir a apresentar. (Algumas Exigências para o Funcionamento de Curso de Enfermagem a Qualquer Nivel - Anexo 1) 
- MUNICIPIOS QUE, além da população e número de leitos, acima de 100, POSSUAM RECURSOS HUMANOS DE ENFERMAGEM, ou seja, enfermeiras e técnicos de enfer magem, em número suficiente, para o ensino de enfermagem a nível de 28 grau. DEVEM APRESENTAR, ain da, no mínimo, uma UNIDADE SANITARIA.

- MUNICIPIOS QUE, além dos demais critérios citados anteriormente, POSSUAM ESCOLAS DE 29 GRAU.

4.5.1 - PrimeIRo CRITÉRIO : municípios com mais de 30.000 habitantes. 


\section{TABELA 35}

Relação de Municípios do Estado do Paranā com mais de 30.000 habitantes, segundo os Distritos Sanitārios - 1975

\begin{tabular}{|c|c|}
\hline DISTRITOS SANITARIOS (l) & $P O P \cup L A C \AA \cap$ (2) \\
\hline D.S. Metropolitano & \\
\hline 1. Curitiba & 760.808 \\
\hline 2. Campo Largo & 43.405 \\
\hline 3. São José dos Pinhais & 43.170 \\
\hline 18 D.S. & \\
\hline 1. Paranaguá & 76.748 \\
\hline $20 \mathrm{D.S}$. & \\
\hline 1. Lapa & 37.223 \\
\hline 39 D.S. & \\
\hline 1. Ponta Grossa & 158.262 \\
\hline 2. Castro & 43.463 \\
\hline 3. Ortigueira & 44.764 \\
\hline 4. Telèmaco Borba & 44.833 \\
\hline 49 D.S. & \\
\hline 1. Irati & 39.485 \\
\hline 2. Prudentópolis & 36.745 \\
\hline 50 D.S. & \\
\hline 1. Guarapuava & 134.507 \\
\hline 2. Laranjeiras do Sul & 47.582 \\
\hline
\end{tabular}




\section{Continua}

\begin{tabular}{|c|c|}
\hline DISTRITOS SANITARIOS (I) & 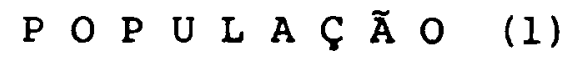 \\
\hline 3. Palmital & 35.406 \\
\hline 4. Pitanga & 77.085 \\
\hline 69 D.S. & \\
\hline 1. União da Vitória & 33.209 \\
\hline 78 D.S. & \\
\hline 1. Pato Branco & 40.995 \\
\hline 2. Chopinzinho & 32.681 \\
\hline 3. Dois Vizinhos & 44.943 \\
\hline 4. São João do Ivaí & 52.925 \\
\hline 89 D.S. & \\
\hline 1. Francisco Beltrão & 44.210 \\
\hline 2. St8 Antonio do Sudoeste & 35.721 \\
\hline 3. Salto do Lontra & 37.957 \\
\hline 90 D.S. & \\
\hline 1. Foz do Iguaçū & 47.696 \\
\hline 2. Matelândia & 33.938 \\
\hline 3. Medianeira & 42.962 \\
\hline 4. Santa Helena & 37.037 \\
\hline 5. São Miguel do Iguaçú & 34.859 \\
\hline $109 \mathrm{D.S}$. & \\
\hline 1. Cascavel & 128.536 \\
\hline 2. Céu Azul & 32.075 \\
\hline 3. Assis Chateaubriand & 108.535 \\
\hline
\end{tabular}


Continua

\begin{tabular}{|c|c|}
\hline DISTRITOS SANITARIOS (l) & $P \circ P \cup L A \& \AA \circ \quad(1)$ \\
\hline 4. Capitão Leônidas Marques & 32.158 \\
\hline 5. Catanduvas & 35.697 \\
\hline 6. Corbélia & 54.687 \\
\hline 7. Formosa do Oeste & 61.114 \\
\hline 8. Guaraniaçū & 39.528 \\
\hline 9. Marechal Cândido Rondon & 60.194 \\
\hline 10. Nova Aurora & 42.124 \\
\hline 11. Palotina & 59.356 \\
\hline 12. Toledo & 97.688 \\
\hline 119 D.S. & \\
\hline 1. Campo Mourão & 107.790 \\
\hline 2. Barbosa Ferraz & 46.243 \\
\hline 3. Campina da Lagoa & 48.359 \\
\hline 4. Goio-Erê & 108.475 \\
\hline 5. Engenheiro Beltrão & 31.342 \\
\hline 6. Mamboré & 42.728 \\
\hline 7. Ubiratã & 49.619 \\
\hline 120 D.S. & \\
\hline 1. Umuarama & 139.536 \\
\hline 2. Guaíra & 45.523 \\
\hline 3. Terra Roxa do Oeste & 52.823 \\
\hline 4. Altônia & 48.059 \\
\hline 5. Cruzeiro do Oeste & 46.019 \\
\hline 6. Alto Piquiri & 45.354 \\
\hline 7. Iporã & 80.623 \\
\hline 8. Maria Helena & 46.016 \\
\hline 9. Pérola & 30.102 \\
\hline
\end{tabular}


Continua

\begin{tabular}{l|}
\hline DISTRITOS SANITARIOS (1) \\
\hline 139 D.S.
\end{tabular}

P O P U L A \& $\cong$ O (I)

1. Cianorte

64.533

149 D.S.

1. Paranavai

62.759

150 D.S.

1. Maringá

2. Marialva

3. Nova Esperança

137.810

39.806

31.688

168 D.S.

1. Apucarana

81.985

2. Arapongas

3. Faxinal

58.633

37.583

4. Grandes Rios

44.516

5. Ivaiporã

6. Jardim Alegre

78.110

38.654

7. Mandaguarí

33.140

170 D.S.

1. Londrina

2. Cambé

3. Ibiporã

4. Rolândia

261.608

40.668

31.007

54.763

189 D.S.

1. Cornélio Procópio 
Conclusão

\begin{tabular}{l|c}
\hline DISTRITO SANITARIO (I) & 32.004 \\
\hline 2. Assaí & 40.780 \\
3. Bandeirantes & \\
& \\
199 D.S. & 42.875 \\
1. Jacarezinho & 35.133 \\
2. Ibaiti & 43.162 \\
3. St8 Antonio da Platina & \\
\hline
\end{tabular}

Fonte: (1) e (2) - Secretaria de Estado da Saúde e do Bem Estar Social do Parana (Grupo de Planejamento Setorial) 1978 (dados de 1975)

Segundo o critério: municípios com mais de 30.000 hạ bitantes, observa-se que, em 1975, dos 288 municípios existentes no Estado do Paranã, apenas 78 contam com população acima de 30.000 habitantes. (Tabela 35)

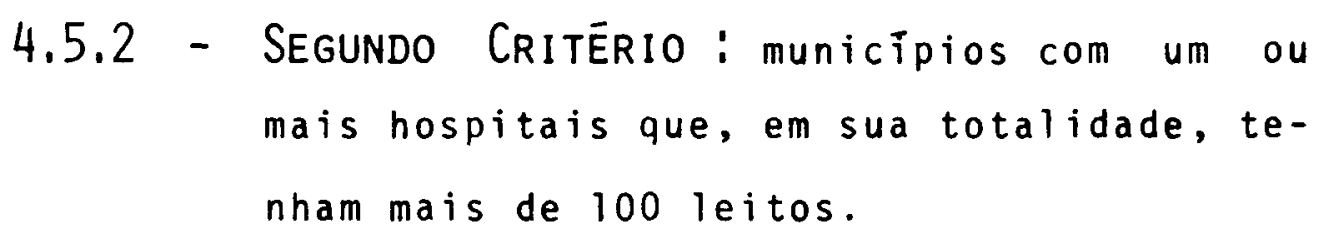

\section{TABELA 36}

Relação de Municīpios do Estado do Paranā que apresentam um ou mais hospitais com mais de 100 leitos - 1975

\begin{tabular}{|c|c|c|c|}
\hline \multirow[b]{2}{*}{ DISTRITO SANITARIO } & \multirow[b]{2}{*}{$\begin{array}{c}\text { NQ DE } \\
\text { HOSPITAIS }\end{array}$} & \multicolumn{2}{|c|}{$\begin{array}{llllll}L & E & I & T & O & S \\
\end{array}$} \\
\hline & & NQ & $\begin{array}{c}\text { Razão/ } \\
1.000 \text { hab. }\end{array}$ \\
\hline D.S Metropolitano & & & \\
\hline 1. Curitiba & 46 & 6.229 & 8,2 \\
\hline
\end{tabular}


Continua

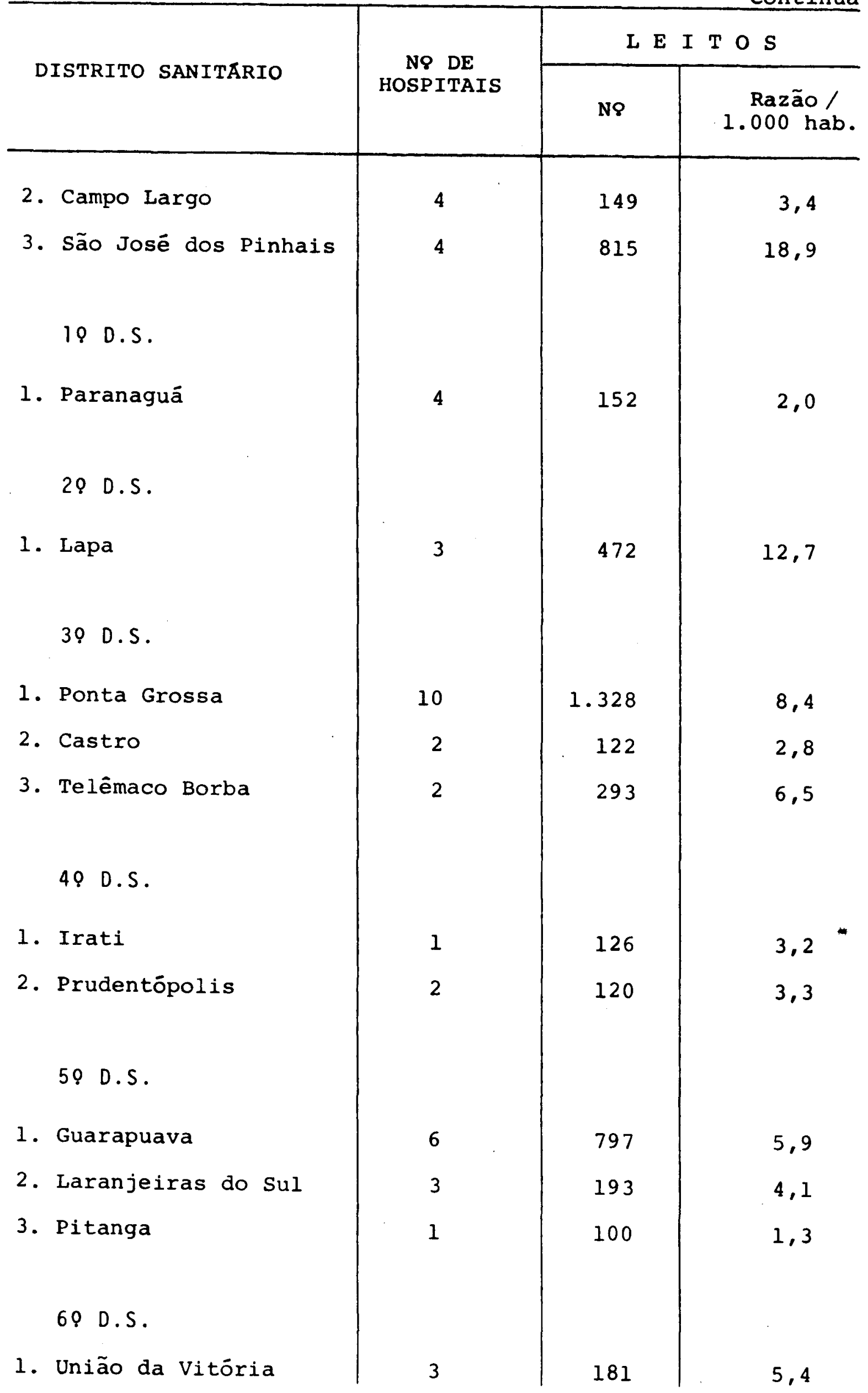


Continua

\begin{tabular}{|c|c|c|c|}
\hline \multirow[b]{2}{*}{ DISTRITO SANITÁRIO } & \multirow[b]{2}{*}{$\begin{array}{c}\text { NQ DE } \\
\text { HOSPITAIS }\end{array}$} & \multicolumn{2}{|c|}{ L E I T O S } \\
\hline & & NQ & $\begin{array}{l}\text { Razão/ } \\
1.000 \mathrm{hab} .\end{array}$ \\
\hline 70 D.S. & & & \\
\hline 1. Pato Branco & 3 & 296 & 7,2 \\
\hline 2. São João do Ivai & 4 & 139 & 2,6 \\
\hline 80 D.S. & & & \\
\hline 1. Francisco Beltrão & 4 & 174 & 4,0 \\
\hline 2. Sto Antonio do Sudoeste & 3 & 102 & 2,9 \\
\hline 3. Salto do Lontra & 3 & 107 & 2,8 \\
\hline 90 D.S. & & & \\
\hline 1. Foz do Iguaçú & 3 & 360 & 7,6 \\
\hline 2. Medianeira & 4 & 142 & 3,3 \\
\hline 109 D.S. & & & \\
\hline 1. Cascavel & 12 & 610 & 4,7 \\
\hline 2. Assis Chateaubriand & 5 & 274 & 2,5 \\
\hline 3. Marechal Cândido Rondon & 9 & 376 & 6,2 \\
\hline 4. Palotina & 2 & 139 & 2,3 \\
\hline 5. Toledo & 2 & 258 & 2,6 \\
\hline 119 D.S. & & & \\
\hline 1. Campo Mourão & 10 & 372 & 3,5 \\
\hline 2. Campina da Lagoa & 6 & 107 & 2,2 \\
\hline 3. Goio-Erê & 5 & 226 & 2,1 \\
\hline 4. Ubiratã & 4 & 134 & 2,7 \\
\hline
\end{tabular}


Continua

\begin{tabular}{|c|c|c|c|}
\hline \multirow[b]{2}{*}{ DISTRITO SANITARIO } & \multirow{2}{*}{$\begin{array}{c}\text { N\& DE } \\
\text { HOSPITAIS }\end{array}$} & \multicolumn{2}{|c|}{ L E I TOS } \\
\hline & & N8 & $\begin{array}{c}\text { Razão / } \\
1.000 \text { hab. }\end{array}$ \\
\hline 129 D.S. & & & \\
\hline 1. Umuarama & 12 & 436 & 3,1 \\
\hline 2. Altônia & 4 & 195 & 4,0 \\
\hline 3. Iporã & 5 & 108 & 1,3 \\
\hline 139 D.S. & & & \\
\hline 1. Cianorte & 4 & 185 & 2,9 \\
\hline 149 D.S. & & & \\
\hline 1. Paranavaí & 9 & 332 & 5,3 \\
\hline 150 D.S. & & & \\
\hline 1. Maringā & 15 & 934 & 6,8 \\
\hline 2. Nova Esperança & 5 & 118 & 3,7 \\
\hline 169 D.S. & & & \\
\hline 1. Apucarana & 6 & 490 & 6,0 \\
\hline 2. Arapongas & 2 & 108 & 1,8 \\
\hline 3. Faxinal & 1 & 100 & 2,7 \\
\hline 4. Ivaiporã & 4 & 138 & 1,8 \\
\hline 5. Mandaguarí & 5 & 429 & 13,0 \\
\hline 179 D.S. & & & \\
\hline 1. Londrina & 14 & 1.309 & 5,0 \\
\hline 2. Ibiporã & 2 & 116 & 3,7 \\
\hline 3. Rolândia & 6 & 319 & 5,8 \\
\hline
\end{tabular}


Conclusão

\begin{tabular}{|c|c|c|c|}
\hline \multirow[b]{2}{*}{ DISTRITO SANITARIO } & \multirow[b]{2}{*}{$\begin{array}{c}\text { NQ DE } \\
\text { HOSPITAIS }\end{array}$} & \multicolumn{2}{|c|}{$L E I T O S$} \\
\hline & & NQ & $\begin{array}{l}\text { Razão / } \\
1.000 \text { hab. }\end{array}$ \\
\hline 188 D.S. & & & \\
\hline 1. Cornélio Procōpio & 4 & 306 & 5,9 \\
\hline 2. Bandeirantes & 1 & 150 & 3,7 \\
\hline 190 D.S. & & & \\
\hline 1. Jacarezinho & 1 & 113 & 2,6 \\
\hline 2. St8 Antonio da Platina & 1 & 130 & 3,0 \\
\hline
\end{tabular}

Fonte: Secretaria de Estado da Saūde e do Bem Estar Social do Paraná (Grupo de Planejamento Setorial) - 1978 (dados de 1975)

Conforme já citado no item 4.5.1 o Estado do Paraná possui 288 municípios. Destes, 228 possuem hospitais ${ }^{48}$.

De acordo com o critério: municípios com um ou mais hospitais que, em sua totalidade, tenham mais de 100 leitos, ve rifica-se que apenas 49 municĺpios se enquadram neste critério. (Tabela 36)

4.5 .3 - TERCEIRO CRITERIO: municīpios que, além da população e número de leitos exigidos, possuam no minimo uma(1) Unidade Sanitária e Recursos Humanos de Enfermagem, ou seja, uma ou mais enfermeiras, ou ainda técnico de enfermagem (elemento que poderā ser habilitado para participar na formação do pessoal auxiliar). - TABELA 37 


\section{TABELA 37}

Relação de Municípios do Estado do Paranā, que apresentam população superior a 30.000 habitantes, hospitais que, em sua totalidade, possuam mais de 100 leitos, uma ou mais Unidades Sanitárias e recursos humanos de enfermagem - 1975

\begin{tabular}{|c|c|c|c|c|c|c|}
\hline \multirow{2}{*}{$\begin{array}{r}(1) \\
\text { DISTRITO } \\
\text { SANITARIO }\end{array}$} & \multirow{2}{*}{$\begin{array}{l}(2) \\
\text { POPU- } \\
\text { LAÇÃO }\end{array}$} & \multirow{2}{*}{$\begin{array}{r}(3) \\
\text { HOSPI- } \\
\text { TAIS }\end{array}$} & \multirow{2}{*}{$\begin{array}{r}\text { (4) } \\
\text { LEITOS }\end{array}$} & \multirow{2}{*}{$\begin{array}{l}(5) \\
\text { UNIDADE } \\
\text { SANIT. }\end{array}$} & \multicolumn{2}{|c|}{$\begin{array}{c}\text { RECURSOS HUMANOS (6) } \\
\text { DE ENFERMAGEM }\end{array}$} \\
\hline & & & & & Enfermeiras & $\begin{array}{l}\text { Técnico } \\
\text { de Enfer. }\end{array}$ \\
\hline $\begin{array}{l}\text { D.S. METROPO } \\
\text { LITANO }^{-}\end{array}$ & & & & & & \\
\hline 1. Curitiba & 760.808 & 46 & 6.229 & 15 & 128 & 47 \\
\hline $\begin{array}{l}\text { 2. São José dos } \\
\text { Pinhais }\end{array}$ & 43.170 & 4 & 815 & 1 & 2 & - \\
\hline 10 D.S. & & & & & & \\
\hline 1. Paranaguá & 76.748 & 4 & 152 & 1 & 2 & 2 \\
\hline 39 D.S. & & & & & & \\
\hline 1. Ponta Grossa & 158.262 & 10 & 1.328 & 2 & 11 & 1 \\
\hline 49 D.S. & & & & & & \\
\hline 1. Irati & 39.485 & 1 & 126 & 4 & 2 & - \\
\hline 59 D.S. & & & & & & \\
\hline 1. Guarapuava & 134.507 & 6 & 797 & 7 & 1 & 4 \\
\hline 2. Pitanga & 77.085 & 1 & 100 & 1 & 1 & 1 \\
\hline 99 D.S. & & & & & & \\
\hline 1. Foz do Iguaçū & 47.696 & 3 & 360 & 2 & 5 & 1 \\
\hline
\end{tabular}


Conclusão

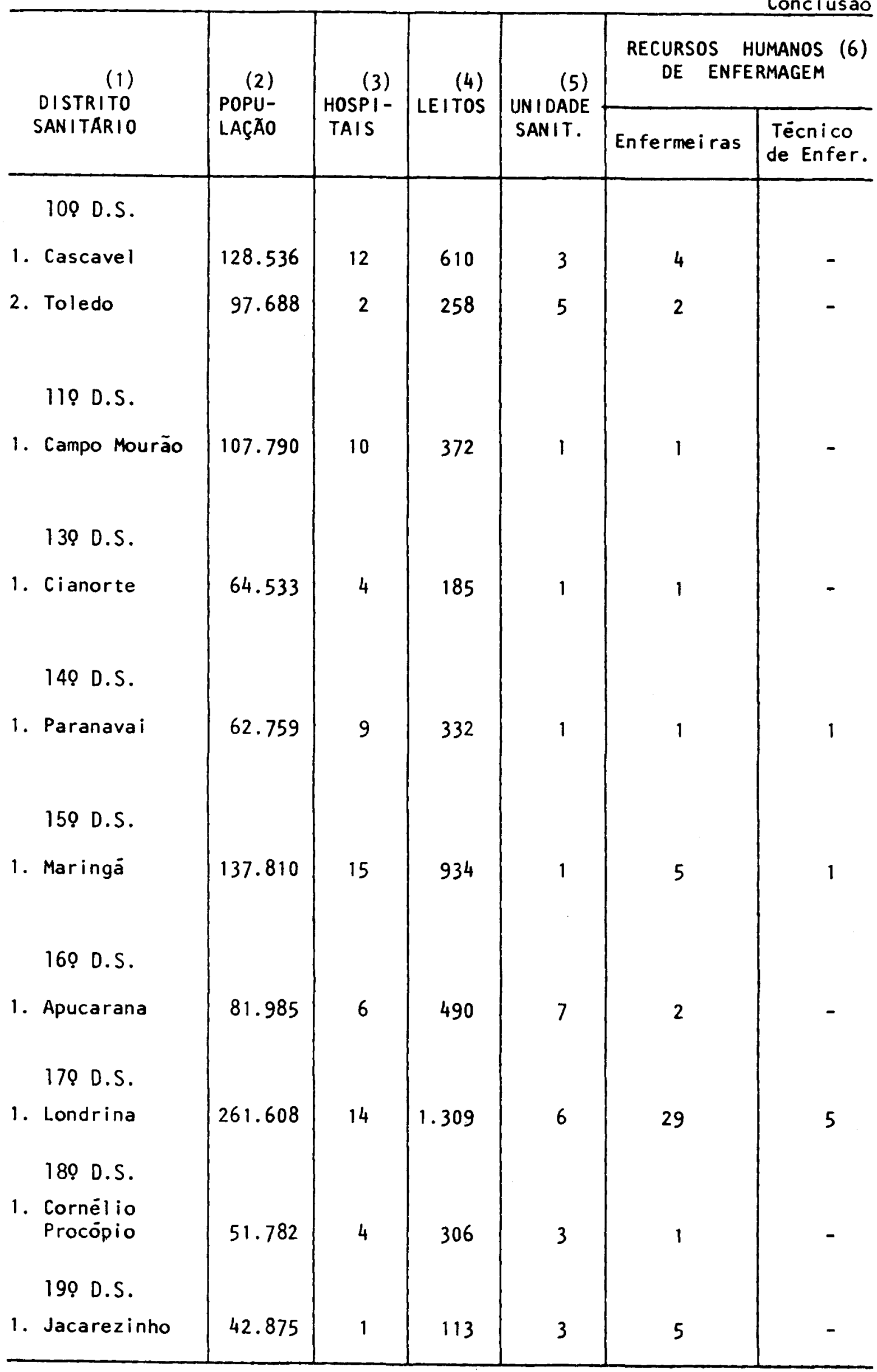

Fonte: (1), (2), (3), (4) e (5) - Grupo de Planejamento Setorial da SESB/ PR - 1978 (dados de 1975). (6) SESB/PR; - INAMPS/PR e COREN/PR - 1978 (dados de 1977). 


\subsection{4 - QUARTO CRITÉRIO : municípios que, além de preencherem os critérios anteriores, possuam Escolas de Ensino de 29 Grau.}

\section{TABELA 38}

Relação de Municípios do Estado do Paraná, que apresentam população superior a 30.000 habitantes, hospitais que em sua totalidade, possuam mais de 100 leitos, uma ou mais Uni dades Sanitārias, uma ou mais enfermeiras, técnicos de enfermagem e uma ou mais escolas de ensino de 29 grau - 1975

\begin{tabular}{|c|c|c|c|c|c|c|c|}
\hline \multirow{2}{*}{$\begin{array}{r}\text { (i) } \\
\text { DISTRITO } \\
\text { SANITARIO }\end{array}$} & \multirow{2}{*}{$\begin{array}{c}(2) \\
\text { POPU- } \\
\text { LAÇĀO }\end{array}$} & \multirow{2}{*}{$\begin{array}{r}(3) \\
\text { HOSPI } \\
\text { TAIS }\end{array}$} & \multirow{2}{*}{$\begin{array}{r}\text { (4) } \\
\text { LEITOS }\end{array}$} & \multirow{2}{*}{$\begin{array}{r}\text { (5) } \\
\text { UNID. } \\
\text { SANIT. }\end{array}$} & \multicolumn{2}{|c|}{$\begin{array}{l}\text { RECURSOS HUMA }(6) \\
\text { NOS DE ENFERMAGGEM }\end{array}$} & \multirow{2}{*}{$\begin{array}{r}(7) \\
\text { ESCOLAS } \\
\text { DE } 2: \\
\text { GRAU }\end{array}$} \\
\hline & & & & & $\begin{array}{l}\text { Enfer- } \\
\text { meiras }\end{array}$ & $\begin{array}{l}\text { Técnico } \\
\text { de Enfer. }\end{array}$ & \\
\hline D.S.METROPOL & & & & & & & \\
\hline 1. Curitiba & 760.808 & 46 & 6.229 & 15 & 128 & 47 & 61 \\
\hline $\begin{array}{l}\text { 2. São José dos } \\
\text { Pinhais }\end{array}$ & 43.170 & 4 & 815 & 1 & 2 & - & 2 \\
\hline 19 D.S. & & & & & & & \\
\hline 1. Paranaguä & 76.748 & 4 & 152 & 1 & 2 & 2 & 5 \\
\hline 39 D.S. & & & & & & & \\
\hline 1. Ponta Grossa & 158.262 & 10 & 1.328 & 2 & 11 & 1 & 8 \\
\hline 40 D.S. & & & & & & & \\
\hline 1. Irati & 39.485 & 1 & 126 & 4 & 2 & - & 3 \\
\hline 59 D.S. & & & & & & & \\
\hline 1. Guarapuava & 134.507 & 6 & 797 & 7 & 1 & 4 & 4 \\
\hline 2. Pitanga & 77.085 & 1 & 100 & 1 & 1 & 1 & 2 \\
\hline
\end{tabular}


Conclusão

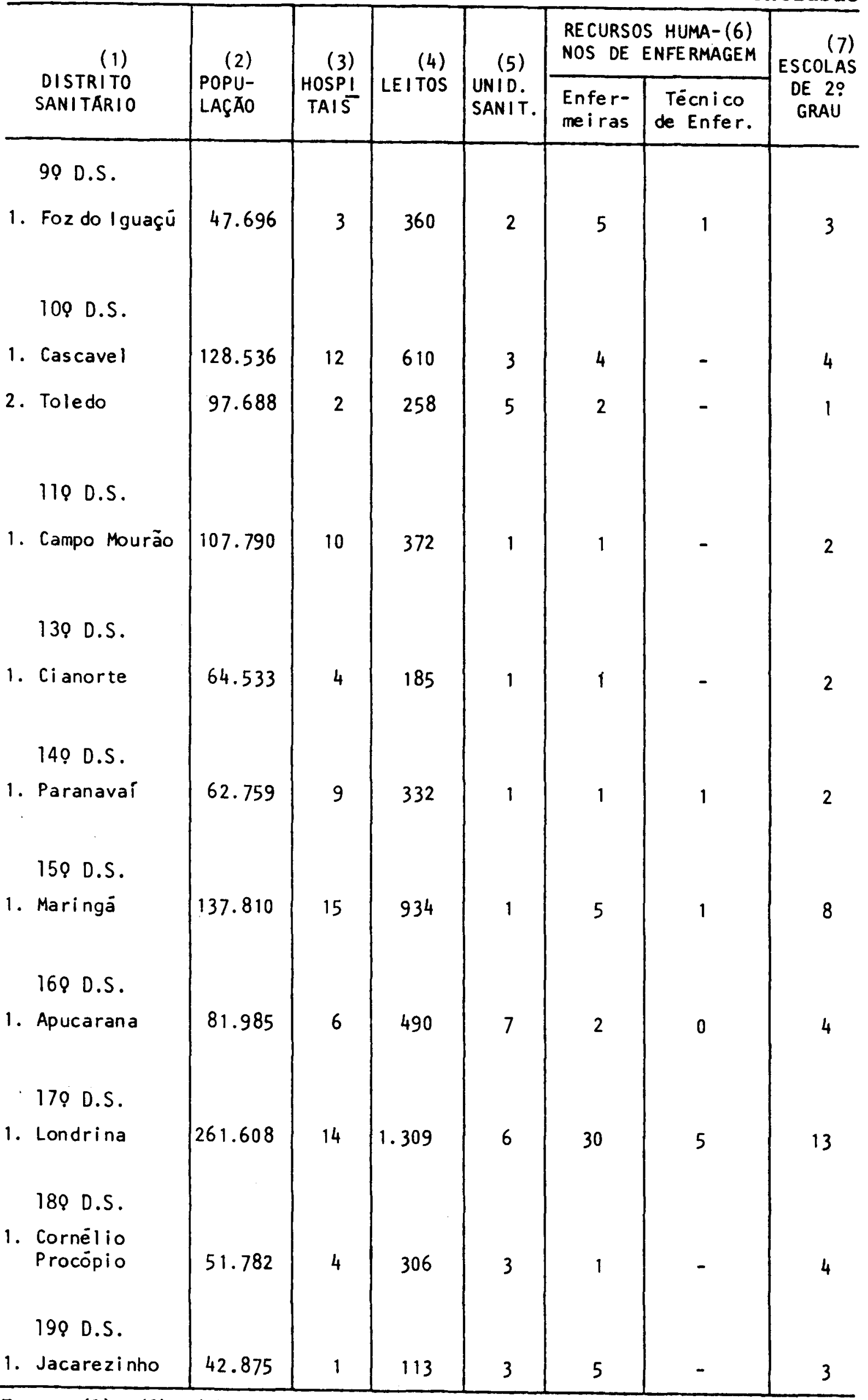

Fonte: (1), (2), (3), (4) e (5) - Grupo de Planejamento Setorial da SESB/PR 1978 (dados de 1975). (6) SESB/PR - INAMPS/PR e COREN/PR - 1978 (da dos de 1977) (7) Secretaria de Estado da Educação e da Cultura/PR. 1978 (dados de 1977) 
Verifica-se, nas TABELAS 37 e 38 que apenas 18 municípios, do Estado do Paranā, apresentam integralmente os critérios con siderados essenciais à implantação de Cursos de Técnicoe de Au xiliar de Enfermagem.

Pelos resultados obtidos, relativos aos critérios, ob serva-se que:

- dos 288 municípios existentes 78 contam com popula ção acima de 30.000 habitantes. (TABELA 35)

- dos 78 municípios, com população acima de 30.000 habitantes, 49 possuem um ou mais hospitais que, em sua totalidade, apresentam mais de 100 leitos. (TABELA 36)

- dos 49 municípios que possuem um ou mais hospitais, contando, em sua totalidade, com mais de 100 leitos, apenas 18 apresentam, alëm desse critério, uma ou mais Unidades Sanitärias, recursos humanos de enfermagem (uma ou mais enfermeiras, além de técnicos de enfermagem) e, uma ou mais escolas de ensi no de $2:$ grau. (TABELAS 37 e 38 )

Segundo o Conselho Estadual de Educação/RS ${ }^{14}$, para 0 funcionamento da habilitação de enfermagem, ao nível de 28 grau, devem ser consideradas não só as necessidades globais do Estado, mas, principalmente, aquelas dentro do distrito geo-educacional em que se localizam os cursos solicitados.

Esses cursos devem ser implantados, onde existem con dições mais favoráveis, tais como: uma infra-estrutura capaz de suportar as necessidades de recursos físicos e humanos indispensáveis à instalação dos mesmos. Devem ser localizados em centros maiores, onde apresentem as condições mínimas para um 
bom nível de funcionamento dos cursos de técnico e de auxiliar de enfermagem.

Ainda, segundo o $\mathrm{CEE} / \mathrm{RS}^{14}$, os fatores educacionais, conômicos e sociais devem ser levados em conta na instalação desses cursos.

Partindo dessas fundamentações, acredita-se que os critérios adotados, no presente trabalho, para a instalação de cursos de técnico e de auxiliar de enfermagem no Estado do Paraná, estão de certa forma, de acordo com o estudo já efetuado no Estado do Rio Grande do Sul, em 1974 , cujos resultados vem possibilitando tomadas de medidas à implantação desses cursos no Estado em referência.

4.6 - INDICACÃO DE MUNICİPIOS PARA A IMPLAN -
TAÇ̃̃O DE CURSOS TÉCNICOS E DE AUXILIARES
DE ENFERMAGEM NO ESTADO DO PARANĀ, A
CURTO E MÉdIO PRAZOS

Do estudo geral efetuado sobre os 288 municípios do Estado do Paranā, distribuídos em um(1) Distrito Sanitário Metropolitano e em dezenove (19) Distritos Sanitários, destacouse, numa primeira etapa, municípios com mais de 30.000 habitan tes, para uma possível implantação de Cursos Técnicos e de Auxiliares de Enfermagem.

Posteriormente, foram selecionados, da lista acima, municípios que possuiam no mínimo uma Unidade Sanitária e um ou mais hospitais, contando, em sua totalidade, com mais de 100 leitos, número esse considerado como o mínimo indispensável pą ra oferecer experiências à prática profissional de Enferma- 
gem $^{14}, 50$. Finalmente, na etapa seguinte, considerou-se $\circ$ número de profissionais de enfermagem, bem como o número de escolas de 28 grau. Da listagem precedente, foram indicados municípios onde existe a possibilidade de implantação, a curto e médio pra zos, de cursos Técnicos e de Auxiliares de Enfermagem.

Justifica-se a indicação de alguns municípios no Estado do Paraná, além dos critérios adotados para a sua seleção, as projeções de necessidades de formação de técnicos e de auxiliares de enfermagem, para os serviços hospitalares, parahospitalares e de saúde pública, em 1980, conforme constam das TABELAS 32 e 33 .

\subsection{1 - PARA A IMPLANTAÇÃO DE CURSOS TÉCNICOS DE ENFERMAGEM}

Os estudos demonstram que a implantação de Cursos Téc nicos deverá ser feita em duas fases: a curto e médio prazos.

a) A Curto Prazo (dois a très anos)

Observa-se, pela Tabela 38, que apenas dois municipios apresentam as condições básicas, para a implantação desse Curso:

- Curitiba

- Londrina

Alēm desses, o município de Ponta Grossa estaria apto, desde que fossem aumentados seus recursos humanos de enfer magem, ou seja, enfermeiras licenciadas. 
Tendo em vista que Curitiba possui, apenas, dois cursos técnicos de enfermagem e que as necessidades dessa localidade são bem maiores, por contar com maior população, número de hospitais e de leitos, além de maior número e diversificação de serviços de saúde, a absorção desse pessoal, provavelmente, seria imediata. Portanto, a prioridade para a implantação desse Curso seria em primeiro lugar em Curitiba e não em Londrina, que já conta com quatro cursos e cuja população é quatro vezes menor, com recursos assistenciais em número inferior.

b) A Médio Prazo (quatro a cinco anos)

Em Foz do Iguaçu, Maringá e Cascavel poderia ser implantada essa modalidade de curso, desde que satisfizessem o número de recursos humanos de enfermagem necessário ao ensino teórico-prático.

Nos demais municípios, considera-se indicada a realização de estudos mais detalhados quanto à situação da população, de hospitais, de leitos e de recursos humanos de enfermagem, necessários tanto para o ensino teórico, como para a prática profissional.

Em Maringá, seria de suma importância que fosse implantado curso desse nível, uma vez que possui os requisitos básicos, como hospitais, leitos, unidades sanitárias e recursos humanos em número suficiente. A formação desse elemento ocupacional iria, provavelmente, melhorar a assistência de enfermagem nos hospitais, já que essa localidade possui apenas um curso de auxiliar de enfermagem. 


\subsection{2 - PARA A IMPLANTAGÃo DE CURSOS DE AU - XILIARES DE ENFERMAGEM}

As exigências para a Instalação de um Curso de Auxiliar de Enfermagem são menores, quanto aos recursos físicos e equipamentos requeridos, $j a ́$ que o mesmo apresenta uma carga horáría teórica bem inferior ao do Técnico de Enfermagem. Portan to, mals municípios teriam condições para a sua implantação, desde que contassem com maior número de enfermetras, ou seja, enfermeiras licenciadas para o ensino e de técnicos de enfermagem, que poderiam vir a auxiliar como monitores durante o desenvolvimento do curso.

ocorrendo essa situação, os seguintes municipios apresentarıam as condições necessárias à Implantação desses Cursos:

a) A Curto Prazo (dois a trēs anos)

Pelos critérios mínimos estabelecidos, estariam habilitados os seguintes municipios:

- Maringá

- Ponta Grossa

- Londrina

- Curitiba

- Cascave 1

- Apucarana

- Foz do Iguaçu

- Jacarezinho

Entretanto, convém salientar que a formação do Auxi- 
liar de Enfermagem nesses municípios poderia ser em regime intensivo, na função de qualificação e dirigida, para uma faixa etária, de preferência, acima de 18 anos.

Sendo por via regular, a idade mínima aconselhada é de 16 anos completos ${ }^{45}$.

Com essa modalidade de formação, provavelmente, haverá evasão reduzida, formação rápida e utilização imediata pelo mercado de trabalho.

b) A Médio Prazo (quatro a cinco anos)

Poderia ser nos seguintes municipios:

- Paranaguá

- São José dos Pinhais

- Cornélio Procópio

- Guarapuava

- Irati

- Toledo

- Campo Mourão

- Paranavaí

- Pitanga

- Cianorte

Entretanto, sua implantação estaria na dependência de haver, nessas localidades, recursos humanos de enfermagem, de, no mínimo, três enfermeiras licenciadas.

De preferência, a formação deverá ser reallzada, tạ bém, pelo sistema supletivo, na função de qualificação.

De acordo com a Indicação no $25 / 74$, do Conselho Es- 
tadual de Educação do Estado do Rio Grande do $\mathrm{Sul}^{14}$, referente ao estabelecimento de Diretrizes Gerais para o Planejamento de Té cnico de Enfermagem e de Auxiliar de Enfermagem, observa-se que, dos 229 municípios considerados, no referido estudo:

"O Conselho Estadual de Educação decidiu pela implantação da habilitação de técnico de enfer magem nas cidades de Santa Maria, Passo Fundo, Pelotas e Porto Alegre. Como critério inicial - Conselho Estadual de Educação autorizou essa habilitação nas cidades em que há faculdades de medicina (Parecer 18/73). Isso corresponde, evidentemente, a implantar a habilitação nos maiores centros. Mas é preciso incrementar o processo, através de incentivos segun do as regiões indicadas". ${ }^{14}$," (o grifo é nosso)

Ainda, segundo o CEE/RS:

'Não apenas nessas cidades desenvolver-se-ä o ensino de enfermagem: dentro do planejamento numérico para cada região ele será instalado onde se apresentarem condições suficientes"1. ${ }^{14, m}$

Quanto à formação de auxiliares de enfermagem, segundo a Indicação no 25 , do $\operatorname{CEE} / \mathrm{RS}^{14}$, jā existe um bom número de escolas no Rio Grande do sul e, com um incremento anual do número de matrículas, poder-se-ia atingir a meta estabelecida em 1980, para o Estado em referência.

No Estado do Rio Grande do Sul existia em 1972: 2.480 auxiliares de enfermagem e nenhum técnico de enfermagem. A pro jeção de necessidades estimada para 1980 é da ordem de 7.651 técnicos de enfermagem e 3.825 auxiliares de enfermagem.

m) CONSELHO ESTADUAL DE EDUCAÇÃo, RS. Indicação n $925 / 74$ - Indica orientação a ser adotada na formaçao de técnicos de enfermagem. Documentário, Porto Alegre, (25):355, mar./ maio 1974 . 
Comparando, o presente estudo, com o efetuado no Estado do Rio Grande do Sul, verifica-se uma certa semelhanģa, quanto ao número limitado de localidades que apresentam as con dições mínimas à implantação do Curso Técnico de Enfermagem. Por outro lado, verifica-se que as projeções de necessidades de formação de técnico no Estado do Paraná, para 1980, são menores que as projetadas para o Estado do Rio Grande do Sul, con forme se constata pelas TABELAS 32 e 33 .

Deve-se ressaltar, no entanto, que no Estado do Paranā, a formação de técnicos de enfermagem, teve início, a partir de 1966, e, que em 1969 jā possuia, em seu mercado de traba lho, esse elemento ocupacional.

Quanto às projeções de necessidades de formação de auxiliares de enfermagem, para 1980 , constata-se que no Estado do Paranā são bem superiores daquelas previstas para o Estado do Rio Grande do Sul, ou seja, de ordem de 19.423 auxiliares de enfermagem, para a assistência hospitalar, para-hospitalar e de saúde pública. (TABELAS 32 e 33)

Deve-se, no entanto, considerar que no Rio Grande do Sul, em 1972, já existia um número superior de auxiliares de en fermagem ao do Paraná em 1974, ou seja, 2.480(RS) e 1.177 (PR).

Acredita-se que, além da necessidade de serem implan tados novos cursos nos 18 municípios selecionados no Estado do Paraná, poderiam as escolas já existentes estudar uma forma de incentivar os jovens à realização de cursos profissionalizantes, aumentando, portanto, a sua demanda, com vistas a atingir, em parte, as metas de recursos humanos de enfermagem, pre vistas para 1980 . 


\section{CONCLUSÕES}

Dos estudos realizados a nível de ETECLA e a nivel de Estado, pode-se concluir que:

- O Indice de matrícula nos cursos Técnico de Enfermagem e de Auxiliar de Enfermagem tem aumentado nos ültimos anos e o Indice de evasão está decrescendo sensivelmente. Estes fatos poderiam ser atribuídos à divulgação da ETECLA, através de seus ex-alunos e às atividades extra-classe, desenvolvidas por essa Escola.

- O Indice de alunos concluintes, para ambos os cursos, tem aumentado nos últimos anos atingindo em 1977, mais de 908 . Quanto ao Indice de alunos repetentes, pode-se dizerque o mesmo è inexpressivo.

- A relação docente/aluno na ETECLA apresenta-se aquém da proporção recomendada, fator que encarece o custo/aluno/ano.

- O regime de trabalho das docentes-enfermeiras, para ambos os cursos, oscila entre 12 a 40 horas semanais. Essa dis tribuição pode ser, provavelmente, uma estratégla da ETECLA, pa ra equilibrar o custo/aluno/ano, sem prejuízo da qualidade do ensino. 
- O corpo docente da ETECLA possui um nível de qualifí cação satisfatōrio, uma vez que, a sua maioria, estā constituído de enfermeiras licenciadas, com cursos a nível de especialização.

- O maior Indice de fixação dos egressos de Cursos de Técnico de Enfermagem e de Auxiliar de Enfermagem se dá em hospitais, ou seja, 67,68 e 60,48 , respectivamente. Esse fato é devido, provavelmente, ao tipo de formação recebida e, em parte, aos hospitais que absorvem maior contingente desses elemen tos ocupacionais.

- O Indice de fixação dos egressos, de ambos os cursos, no Estado do Paraná è um dos mais elevados, ou seja, 67,68 para os técnicos de enfermagem e 72,98 para os auxiliares de enfermagem.

- A nova sistemática de ensino modular, no sistema supletivo, função qualificação, facilita a formação sem prejuízo para o aluno, pois no final de cada período, ele obtém Cert1ficado do módulo correspondente, possibilitando sua absorção imediata no mercado de trabalho. Por outro lado, o egresso pode matricular-se no módulo seguinte, proporcionando, desta forma, o acesso vertical na escala ocupacional.

- Existe uma escassez acentuada de recursos humanos de enfermagem em todas as categorias funcionais, tanto para os serviços hospitalares, como para-hospitalares e de saúde pública.

- A projeção numérica desses recursos humanos para 1980 demonstra uma necessidade acentuada de pessoal a ser formado até essa data, o que merece atenção especial dos setores de educação e de saủde. 
- O Paraná conta atualmente com um número bastante significativo de escolas e/ou cursos de enfermagem a nível de 28 grau. Entretanto, a produção desse aparelho formador está aquém da possibilidade de atender o nümero de recursos humanos de enfermagem de nível médio, de acordo com os padrões estabelecidos pela OPS/OMS.

- Segundo os critérios estabelecidos, dos 288 municipios existentes no Estado do Paraná, apenas 18 apresentam todos os requisitos essenciais à implantação de Cursos Técnicos e de Auxiliares de Enfermagem.

- Dos 18 municípios selecionados, somente seis oferecem as condições requeridas para a criação de Cursos técnicos de Enfermagem, sendo três a curto prazo e três a médio prazo. Para o Curso de Auxiliar de Enfermagem, observa-se que todas as localidades poderiam comportar essa modalidade de curso, ou seja, olto a curto prazo e dez a médio prazo, desde que contem com profissionais de enfermagem, tanto para o ensino teórico, como para a prática nos serviços de saúde. 


\section{REFERẼNCIAS BIBLIOGRÁFICAS}

1. ALCANTARA, G. de. o pessoal de enfermagem necessārio em face da realidade sócio-econômica do Brasil. Ribeirão Preto |s.ed.| 1969 .

2. ASSOCIAÇÃo BRASILEIRA DE ENFERMAGEM. Levantamento de recursos e necessidades de enfermagem no Brasil, 1957-58. São Paulo, 1958.

3. BOLETIM $|D A|$ ASSOCIAÇÃo BRASILEIRA DE ENFERMAGEM. São Pau 10, jan. 1974 .

4. BRAGA, Ernani. Educação e treinamento de pessoal para as atividades de saúde. In: CONFERENCIA NACIONAL DE SAODE SOBRE RECURSOS HUMANOS PARA AS ATIVIDADES DE SAODE, 4., Rio de Janeiro, 30 de agosto a 4 de setembro de 1967. Rio de Janeiro, 1967. p.1-9.

5. CONSELho ESTADUAL DE EDUCAÇÃo, PR. Deliberação n\& 27/72 fixa normas para autorização de funcionamento de estabelecimento de ensino de 18 e 28 graus e sua fiscalização oficial. Critéria, Curitiba, (14):213-39, jan./jun. 1972 .

6. Parecer no 93/68. Critéria, Curitiba, (8):161, jul./dez. 1968.

7. Parecer n8 18/73, de 15 de mar. de 1973. Cri- 
tēria, Curitiba, (16):97, jan./jun. 1973.

8. Parecer n\& $36 / 74$ e Deliberação no 30 , de 08 de maio de 1974. Critēria, Curitiba, (18):257-400, jan./ jun. 1974 .

9. Parecer n8 76/75, de 11.04.75. Critéria, Curitiba, (20):177, jan./jun. 1975.

10. Parecer no 191/75, de 21.11.75. Critéria, Curitiba, (21):120, ago./dez. 1975.

11. Parecer n\& 70/78, de 15.02.78. (Não publica do)

12. Parecer no 120/78, de 03.03.78. (Não publicado)

13. CONSElHo ESTAdUAL DE EDUCAÇÃO, PR. Resolução n\& 05/66. Critéria, Curitiba, (3):67-70, jan./jun. 1966.

14. CONSElHO ESTADUAL DE EDUCAÇÃo, RS. Indicação no 25/74 Indica orientação a ser adotada na formação de técnicos de enfermagem. Documentārio, Porto Alegre, (25):345-58, mar./maio 1974 .

15. CONSELHO FEDERAL DE EDUCAÇÃO. Parecer n8 $163 / 72$, aprovado em 28.01.72 : Currículo mínimo dos Cursos de Graduação de Enfermagem e Obstetricia. Brasilia, 1972.

16. Parecer n\& 2.713/74: nível de formação do auxiliar de enfermagem, após promulgação da Lei 5.692/71. Revista Brasileira de Enfermagem, Brasilia, 27 (4):532-48, out./dez. de 1974 .

17. CONSELHo FEDERAL DE EDUCAÇÃo. Comissão de Educação de 18 e 28 graus. Parecer no 1.446/77; validade de curso de 29 
grau em currículos fixados pelo Parecer no $45 / 72$ e posteriormente modificados. Documenta, Brasilia, (199):268, 1977.

18. EQUIVALENCIA de diversos cursos de auxiliar de enfermagem; Conselho Federal de Educação, Resolução n\& 07/77 e Resolução n\& 08/77. Ensino Supletivo, Brasilia, 4 (11):2731,1977 .

19. FUNDAÇÃO IBGE. Departamento de Censos. Censo Demográfico: Brasil. Rio de Janeiro, 1970. (VIII Recenseamento Geral - 1970, Série Nacional, v.l)

20. FURTADO, Jucundino da Silva. Organização e autorização para funcionamento de curso experimental de técnico de enfermagem; Parecer 41/66. Critéria, Curitiba, (3):70-7, jan./jun. 1966 .

21. INDICADORES de Educação. Indicadores Sociais RS, Porto Alegre, $\underline{3}(3): 85-105,1975$.

22. INDICES econômicos nacionais e regionais. Conjuntura Econômica, Rio de Janeiro, 31(4):93, abril 1977.

23. Conjuntura Econômica, Rio de Janeiro, $\underline{32}(6)$ :

148, jan. 1978. .

24. INSTITUTO NACIONAL DE ESTUdOS PEDAGOGICOS. Núcleo Integrado de Estudo de Recursos Humanos para a Saúde. Bases para uma efetiva política de desenvolvimento : educação de recursos humanos e atual mão-de-obra no setor saúde. Rio de Janeiro, 1973.

25. INSTITUTO PRESIDENTE CASTELLO BRANCO. Departamento de Recursos Humanos para a Saúde. Breve análise de mão-deobra do setor saúde organizado. Rio de Janeiro, 1970. 
26. MARTINS, Nara Bevilacqua \& LOURENÇO, Vera Regina. Recursos humanos para o setor saúde no Estado do Paranā. Rio de Janeiro, DRHUS do Instituto Presidente Castello Bran co da Fundação Instituto Oswaldo Cruz, 1974. (Trabalho apresentado no encerramento do estágio realizado no DRHUS, de 02.01 .74 a 22.02 .74$)$

27. MEDEIROS, N.R.D. Relatōrio da Comissão de Documentação e Estudos 1974/75. Revista Brasileira de Enfermagem, Bra sília, 28 (3):85-109, jul./set. 1975.

28. MINISTERIO DA EDUCAÇÃO E CULTURA. Portaria n\& 900/76. DOcumenta, Brasilia, (194):447, 1976.

29 . Portaria n8 106/65. Revista Brasileirade Enfermagem, Brasilia, 19(5/6):699-700, out./dez. 1966.

30. Parecer n\& 3.814, de 12.11.1976. Documenta, Brasilia, (192):17, 1976 .

31. MINISTERIO DA EDUCAÇÃo E CULTURA. Coordenação de LegislaÇão e Normas de Ensino. Departamento de Ensino Supletivo. Parecer n8 15/77. (Não publicado)

32. MINISTERIO DA EDUCAÇÃo E CULTURA. Departamento de Ensino Médio \& Departamento de Ensino Fundamental. Habilitações profissionais no ensino de 28 grau; diretrizes, normas e legislação: Lei no 4.024, de 20 de dezembro de 1961 que fixa as diretrizes e bases da educação nacional (publicada no D.O.U., no 278, de 27.12.1961). Brasilia, Expressão e Cultura/Instituto Nacional do Livro, 1972. p. $31-42$.

33. Habilitações profissionais no ensino de $28 \mathrm{grau}$; diretrizes, normas e legislação: Lei 5.692 de 11 de agosto de 1971 que fixa diretrizes e bases para o ensino 
de 18 e 28 graus. Brasília, Expressão e Cultura/Instituto Nacional do Livro, 1972. p.13-30.

34 . Habilitações profissionais no ensino de 28 grau; diretrizes, normas e legislação: Resolução 853/71 do Con selho Federal de Educação que fixa o núcleo comum para os currículos de ensino de 18 e 28 graus. Brasilia, Expressão e Cultura/Instituto Nacional do Livra 1972. p. $71-4$.

35 . Habilitações profissionais no ensino de 28 grau; diretrizes, normas e legislação: Parecer ns 45/72 do Con selho Federal de Educação que fixa os mínimos a serem $\underline{e}$ xigidos em cada habilitação profissional ou conjunto de habilitações afins no ensino de 28 grau. Brasilia, Expressão e Cultura/Instituto Nacional do Livra 1972. p. $75-103$.

36 . Habilitações profissionais no ensino de 28 grau; diretrizes, normas e legislação: Resolução n8 02 de 27 de jan. de 1972. Brasília, Expressão e Cultura/Institú to Nacional do Livro, 1972.

37. MINISTERIO DA EDUCAÇÃo E CULTURA. Departamento de Ensino Mé dio. Apropriação de custos do ensino a nível de 28 grau. Natal, 1974. (Trabalho apresentado no VI Encontró de Se cretários de Educação e Representantes de Conselhos de Educação, realizado em Natal, de 11 a 15 de fevereiro de $1974)$.

38. MINISTERIO DA EDUCAÇÃo E CULTURA. Departamento de Ensino Sü pletivo. Legislação do ensino supletivo: Parecer n8 699/ 72. Brasilia, 1974. p.19-44 
39. MINISTERIO DA SADDE. Guia para curso intensivo de auxiliar de enfermagem. Rio de Janeiro, Escola Nacional de Saúde Püblica, 1970.

40. MINISTERIO DA SAODE. Divisão Nacional de Organização San1 tária. Setor de Enfermagem. Guia para curso supletivo de auxiliar de enfermagem. Rio de Janeiro, 1975.

41 . Relatōrio de avaliacão do projeto "Formacão de Auxillar de Enfermagem". Rio de Janeiro, 1974.

42. OGUISSO, Taka. Considerações sobre a legislação do ensino e do exercíclo do técnico de enfermageme do auxiliar de enfermagem. Revista Brasileira de Enfermagem, Brasilia, 30 (2):168-77, abr./jun. 1977 .

43. OPS/OMS. Plan decenal de salud para las Américas; informe final de la III Reunión Especial de Ministros de Salud de las Américas. Washington, 1973. (Documento Oficial, 118)

44. PARANA. Secretaria da Educação e Cultura. Portaria no 1.301 de 21.03.66. Critéria. Curitiba, (3):5-6, jan./jun. 1966.

45. PARANA. Secretaria de Estado da Educação e da Cultura. Departamento de Ensino de Segundo Grau. Proposicão das diretrizes curriculares para cursos de auxiliar de enfermagem e técnico de enfermagem. Curitiba, 1978.

46. RELATORIO da Comissão de Atividades Científicas e Documentação da ABEn. Revista Brasileira de Enfermagem, Brasí lia, 30 (4): 386-403, out./dez. 1977.

47. SANTa Catarina. Secretaria da Saúde e Promoção Social. Recursos Humanos. Florianópolis, 1974.

48. SECRETARIA DE ESTADO DA SAODE E DO BEM ESTAR SOCIAL DO PARANA. Cadastro Hospitalar do Estado do Paraná. Curi- 
tiba, 1975 .

49. TOBELEM, Alain. Manual de estudos do custo e da gualidade da educação. Brasilia, Projeto de Planejamento de Recursos Humanos das Nações Unidas, 1975. (BRA/70/550, Relatório Técnico, 13)

50. TURKIEWICZ, Maria et alii. Area Terciária de 29 grau. Curitiba, Comissão Estadual de Currículo do Conselho Estadual de Educação, 1973.

51. TURKIEWCZ, Maria. Experiência de planejamento e execução do Curso Técnico de Enfermagem. Revista Brasileira de Enfermagem, Rio de Janeiro, 21 (6):501-16, dez. 1969.

52. TURKIEWCZ, Maria \& ALMEIDA, Joshie Hayashi de. Uma Experiência de curso de auxiliar de enfermagem em Curitiba. Revista Brasileira de Enfermagem. Rio de Janeiro, 22(1): 34-40, jan./jun. 1970 . 
ANEXO - 1

\section{ALGUMAS EXIGENNCIAS PARA O FUNCIONAMENTO DE CURSO DE ENFERMAGEM A QUALQUER NIVEL}

1. DA DIREÇÃO DA ESCOLA OU COORDENAÇÃO DE CURSO

1.1 - A direção da Escola ou a coordenação de Curso de Enfermagem deverā ser exercido por enfermeiro diplomado, de acordo com a legislação que rege o ensino e o exercício da enfermagem no Território Nacional.

1.1 .1 - Decreto 27.426 de 14 de novembro de 1949 , que regulamenta a Lei 775 previa no Artigo 448:"O Diretor do Curso de Enfermagem ou de Auxiliar de Enfermagem serā, obrigatoriamente, diplomado em Enfermagem, de preferência portador de diploma de Curso de Especialização."

1.1 .2 - Lei 2.604 de 17 de setembro de 1955, que dis-

Fontes: CONSElHo ESTADUAL DE EDUCAÇÃo, RS. Indicą̧ãon $\mathbf{n} 25 / 74$ - Indica orientação a ser adotadana formação de téc nicos de enfermagem. Documentärio, Porto Alegre, (25):345-58, mar./maio 1974 .

TURKIEWCZ, Maria et alii. Area Terciária de 29 grau. Curitiba, Comissão Estadual de Currículo do Conselho Estadual de Educação, 1973. 
põe sobre o exercício de Enfermageme suas fun §̧ões auxiliares no Território Nacional: "Artigo 38: São atribuições dos enfermeiros, além do exercício de enfermagem: a) direção dos Serviços de enfermagem nos estabelecimentos hospitalares e de Saúde Pública de acordo com - Artigo 21 da Lei 775, de 06 de agosto de 1949; b) participação do ensino em escolas de enfer magem e de auxiliar de enfermagem; c) direção da escola de enfermagem e de auxiliar de enfermagem; d) participação nas bancas examina doras de práticos de enfermagem."

1.1.3 - Decreto Federal 50.387 de 28 de março de 1961, que regulamenta o EXERCICIO DE ENFERMAGEM E SUAS FUNÇÕES AUXILIARES NO TERRITORIO NACIONAL: "Artigo 98, letra c, com a mesma redação da letra c, artigo 38, Lei 2.604, explicitada no item 1.1.2".

1.1 .4 - Resolução 05 de 04 de março de 1966, do Conselho Estadual de Educação do Paranā, que organiza e Autoriza o funcionamentode Curso Experimental de Técnico de Enfermagem no Paraná. Artigo 98 - "A direção da escola Técnica de Enfermagem deverá ser exercida por enfermeiro diplomado, nos termos do artigo 98, letra c, do Decreto Federal n8 50.387 de 1961."

1.1 .5 - "Defender a prorrogativa do enfermeiro de ministrar o ensino teórico e prático das disciplinas profissionais e de dirigir Cursos de 
enfermagem nos três níveis, de graduação, tēcnico e de auxiliar de enfermagem" - Política da Associação Brasileira de Enfermagem (ABEN) 1971 .

\section{DO ENSINO DAS DISCIPLINAS PROFISSIONAIS DE ENFERMAGEM}

2.1 - As disciplinas profissionais de enfermagem devem ser lecionadas por enfermeiros diplomados.

2.1 .1 - O Decreto 27.426 de 14 de novembro de 1949, pre via no artigo 20 , item 2 : "O ensino ministrado por professores, inspetores e enfermeiroschefes dos hospitais ou serviços em que se faz estágio, desde que sejam diplomados em enfermagem, quando se tratar das disciplinas de enfermagem".

Artigo 29:"O ensino de enfermagem auxiliar somente poderá ser ministrado por enfermeiro; se rá feito por contrato, nas escolas fiscalizadas, conforme a lei, nas oficiais".

2.1.2 - Lei 2.604 de 17.09.1955, Artigo 39, letra b, diz: "São atribuições do enfermeiro, alēm do exercício de enfermagem, participação do ensi no em escolas de enfermagem e de auxiliar de enfermagem."

2.1 .3 - Decreto 50.387 de 1961, artigo 98, letra b, repete: "Participação do ensino nas Escolas de Enfermagem e de Auxiliar de Enfermagem e treinamento de pessoal em serviço". 
2.1.4 - Portaria 106 de 28.04.1965 - MEC, diz no seu artigo 78: "As disciplinas de cultura geral de verão ser lecionadas por professores legalmen te habilitados e as disciplinas especifícas por enfermeiros diplomados."

2.1.5 - Resolução 27, de 09 de dezembro de 1965, do Conselho Estadual de Educação do Paraná - Cursos Auxiliares de enfermagem, Artigo 88: "as disciplinas gerais obrigatórias do 18 ciclo dos cursos de grau médio deverão ser lecionados por professores legalmente habilitados e devidamente registrados, e as disciplinas especificas, por enfermeiros diplomados em curso superior de Enfermagem ou, na falta destes, por outros profissionais legalmente habilitados."

2.1.6 - Resolução 05, de 04 de março de 1966-CEE/PR, Artigo 88: "As disciplinas obrigatōrias e complementares e práticas educativas deverão ser lecionadas por professores legalmente habilitados e devidamente registrados no Ministério da Educação e Cultura, e as disciplinas específicas, por enfermeiros diplomados em curso superior de enfermagem."

3. DO ENSINO DA PRÁTICA PROFISSIONAL

3.1 - A prática profissional, até então, chamada estágio oobrigatório deverá estar a cargo do enfermeiro ou su- 
pervisora.

3.1 .1 - o Decreto 27.426 , no seu artigo 20, item 2, referido no 2.1 .1 , previa essa exigência.

3.1 .2 - Resolução 27, de 09 de dezembro de 1965, do CEE/PR, Artigo 88, parágrafo único:"Os estágios obrigatórios deverão ser supervisionados por professor enfermeiro."

3.1.3 - Resolução 05, de 04 de março de 1966 do CEE/ PR, Artigo 88, parágrafo único: "Os estágios obrigatórios deverão ser supervisionados por professor enfermeiro e realizados em unidades de enfermagem de hospital e em unidades sanitārias."

4. DA OBRIGATORIEDADE E ENSINO DA PRÁTICA PROFISSIONAL

4.1 - A prática profissional, até então chamada de estágio obrigatório, deverá ser ensinada por enfermeiro.

4.1 .1 - O Decreto 27.427, no artigo 248, previa: "Alēm de comparecimento às aulas teōricas dessas disciplinas, os alunos serão obrigados a estágios em hospitais gerais, sob forma de rodízio.

Artigo 268, Parágrafo Onico: 0 aluno que não houver completado os estágios regulamentares será obrigado a compensá-los, para que possa receber o certificado." 
5. DA PROPORÇÃO NUMÉRICA PROFESSOR / ENFERMEIRO /ALUNO

5.1 - A relação numérica professor/enfermeiro-aluno é de um para 10 a 12 alunos no máximo, por se tratar de ensino individualizado e cujo material didātico principal é "vidas humanas".

6. DOS CAMPOS DE PRÁTICA PROFISSIONAL E ESTÁGIOS

6.1 - A prātica profissional deverá realizar-se em hospitais, Centros de Saúde, Ambulatórios, Dispensários, Escolas e outros Serviços de Saúde e de desenvolvimento da comunidade, mediante convênios ou acordo entre estes estabelecimentos e o nível de habilitação pretendida, para assegurar a sua utilização per manente e adequada como campos de prática profissio nal.

6.2 - A prática profissional e os estágios exigem uma cuidadosa seleção de clínicas e serviços que servirão de campos de experiências na respectiva especialidade, de acordo com as necessidades de aprendizagem dos alunos.

6.3 - Os hospitais e Centros utilizados como campos de ensino de Enfermagem, devem atender as exigências mínimas explicitadas em "Padrões mínimos para campos de estágio" tais como: convênio da escola com o hospital, centro de saúde, número de pacientes, em cada uma das quatro clínicas básicas, compatível com - número de alunos, variedades de diagnósticos, ser 
viço de enfermagem estruturado e dirigido por um enfermeiro, material adequado e suficiente para a execução correta das técnicas e número de alunos, observância da ética profissional médica e de enfermagem ne cessária ao desenvolvimento do estudante.

\section{SERVIÇOS HOSPITALARES EM FUnCIONAMENTO NA REgião}

7.1 - Os hospitais devem assegurar a formação dos estudantes nas áreas previstas pela Lei $5.692 / 71$.

7.2 - Estabelecer um convênio ou acordo entre hospitais e o nível de habilitação profissional pretendido, para assegurar a sua utilização permanente e adequada como campos de prática profissional.

7.3 - Que o percentual ( $(8)$ de ocupação seja em média acima de 608 , para assegurar que o campo de prática profissional seja suficiente para o desenvolvimento de habilidades e destrezas dos estudantes - fatores essenciais para a formação profissional.

7.4 - Ter dotação de equipamento e material adequado e suficiente para a execução correta das tēcnicas de acọ do com o número de alunos e necessidades dos pacientes.

8. UNIDADE SANITÁRIA E OUTRO TIPO DE SERVIÇO AMBULATORIAL PARA A SAÚde EM FunCIONAMENTO NA REgĩ̃o 
estudantes de forma a permitirem complementar às áreas previstas na Lei $5.692 / 71$.

8.2 - Estabelecer um convênio ou acordo entre as Unidades Sanitárias e o nível de habilitação profissional pretendido, para assegurar a sua utilização permanente e adequada como campo de prática profissional.

8.3 - Que o movimento de atendimento seja suficiente para as segurar um bom campo de prática profissional, para o desenvolvimento de habllidades e destrezas dos estudantes - fatores essenciais para a formação profissio nal.

8.4 - Ter dotação de equipamento e material adequado e suficiente para a execução correta das técnicas de acordo com o número de alunos e necessidades de clientes.

9. SALAS PARA AULAS tEŌRICAS E PRĀTICAS

9.1 - Em número suficiente com relação ao número de estudantes.

10. DEPENDÊNCIA PARA ADMINISTRAÇÃo, tais como:

- Direção

- Secretaria

- Biblioteca

- Arquivos

- Sala de professores

- Sala de estudo

- Sala de estar. 
11. DO MATERIAL DIDÁTICO MÍNIMO

- A Escola deve possuir material didático mínimo para onsino de enfermagem ao número proposto de alunos, além de:

- Area Física - Equipamentos

12. DOS CURSOS E CARGAS HORÁRIAS SUGERIDAS

\begin{tabular}{|l|c|c|c|}
\hline \multicolumn{1}{|c|}{$\begin{array}{c}\text { QUALIFICAÇÃo OU } \\
\text { HABILITAÇÃo }\end{array}$} & $\begin{array}{c}\text { MINIMO } \\
\text { DE HORAS }\end{array}$ & $\begin{array}{c}\text { RAZOAVEL } \\
\text { DE HORAS }\end{array}$ & $\begin{array}{c}\text { BOM EM } \\
\text { HORAS }\end{array}$ \\
\hline Visitadora Sanitāria & 600 & 750 & 900 \\
Instrumentadora cirūrgica & 600 & 750 & 900 \\
Auxiliar de enfermagem & 1.080 & 1.200 & 1.400 \\
Técnico de enfermagem & 2.000 & 2.200 & 2.400 \\
\hline
\end{tabular}

13. DA INSPEÇÃO DOS CURSOS DE ENFERMAGEM

13.1 - A inspeção das escolas e cursos de enfermagem está assim prevista no Decreto n\& 50.387 de 28 de março de 1961, Artigo 9:"são atribuições de enfermeiro, além do exercício profissional:

a) Administração dos serviços de enfermagem nos estabelecimentos hospitalares, para-hospitalares e de Saúde Pública, conforme o Artigo 21 da Lei $775 / 49$.

b) Participação no ensino, nas escolas de enfermagem e de auxiliar de enfermagem e no treinamento de pessoal em serviço. 
c) Direção e Inspeção de Escolas de enfermagem e de auxiliar de enfermagem.

d) Participação nas bancas examinadoras de práticos de enfermagem e de concurso para seleção e provimento de cargos de enfermagem e de auxiliar de enfermagem." 
$A-11$

ANEXO - 2

Mapa do Estado do Paraná: Indicação de Municípios para a Implantação de Cursos Técnicos e de Auxiliares de Enfermagem, a Curto e Médio Prazos. 


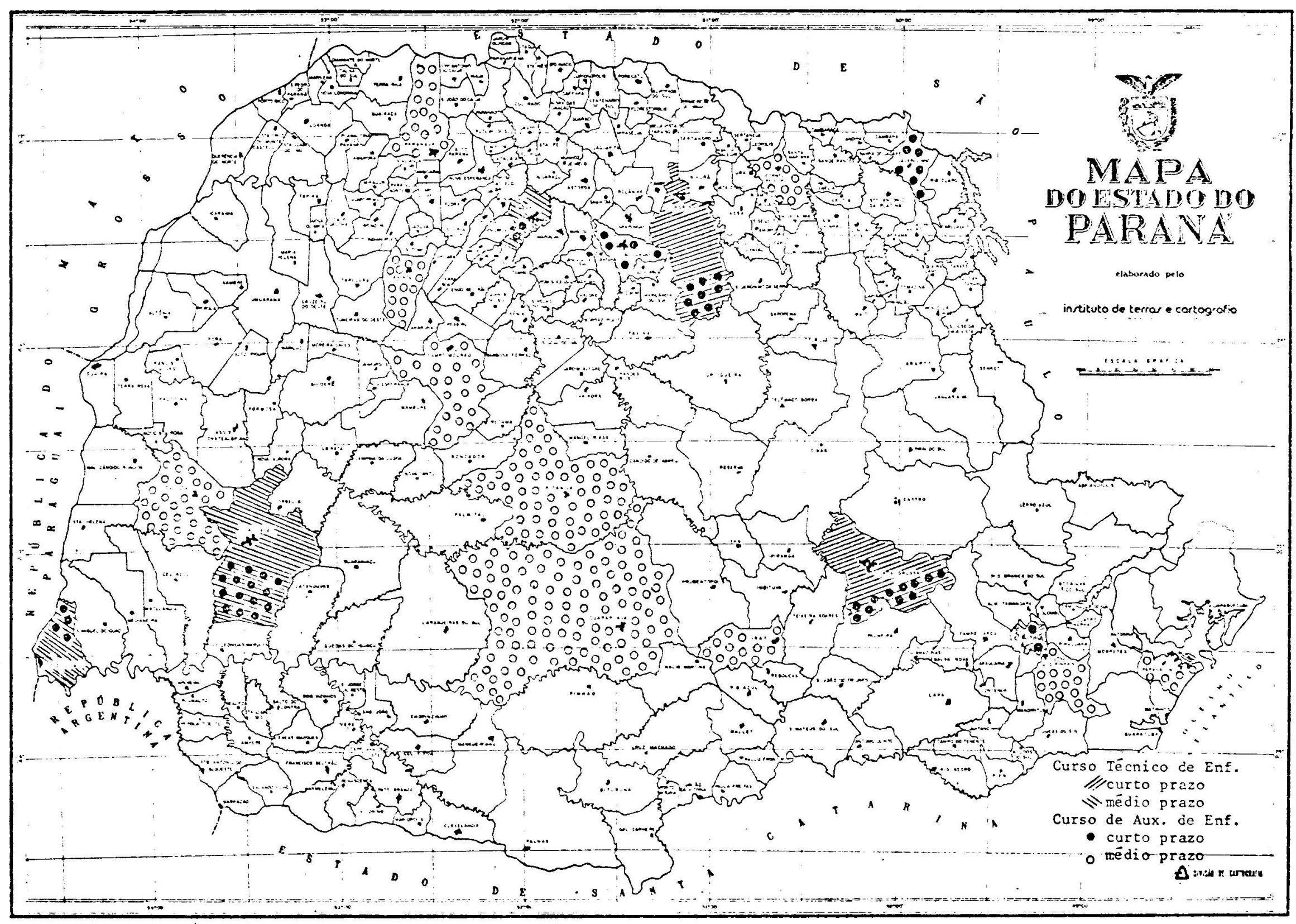


ANEXO - 3

Modelos de Certificados e/ou Diplomas:

- Diploma de Habilitação Profissional, do Curso Técnico de Enfermagem, no Sistema Regular

- Diploma de Habilitação Profissional do Curso Técnico de Enfermagem, no Sistema Supletivo

- Certificado de Habilitação Profissional do Curso de Auxiliar de Enfermagem, no Sistema Regular

- Certificado de Qualificação Profissional - Auxiliar de Enfermagem, no Sistema Supletivo 
REPÚBLICA FEDERATIVA DO BRASIL

STCPETARIA DE GRO DO ESTADO DO PARANA

\section{Escola Técnica de Enfamerasem Catarina Labouré}

Província Brasileira da Congresacajo das limăs (filtzas) de Caridate de São Vicente de Paulo

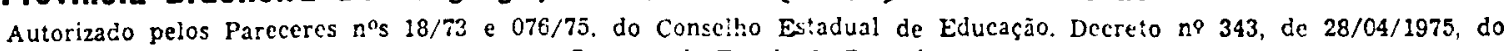

Governo de Estado do Paraná.

ENSINO DE 2. GRAU

DIPLOMA DE HABILITAÇÃO PROFISSIONAL

TÉCNICO EMI ENFERMAGEM

o Diretor da Escola Técnica de Enlermagem Catarina Labouré de acordo com os preceitos legais e de conformidade

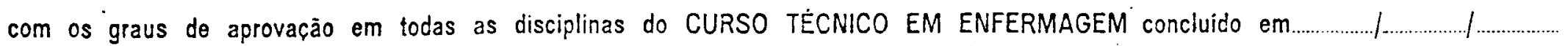

Estado. confere-the o titulo de Técnico em Enfermagem com base no artigo 16, da Lei Federal n. 5.692 , de 11 de agosto de 1971, para que possa gozar de todos os direitos, regalias e prerrogativas concedidas a este titulo pelas leis do Pais.

Curitiba-Paraná, ........... de _.............................. de 19 


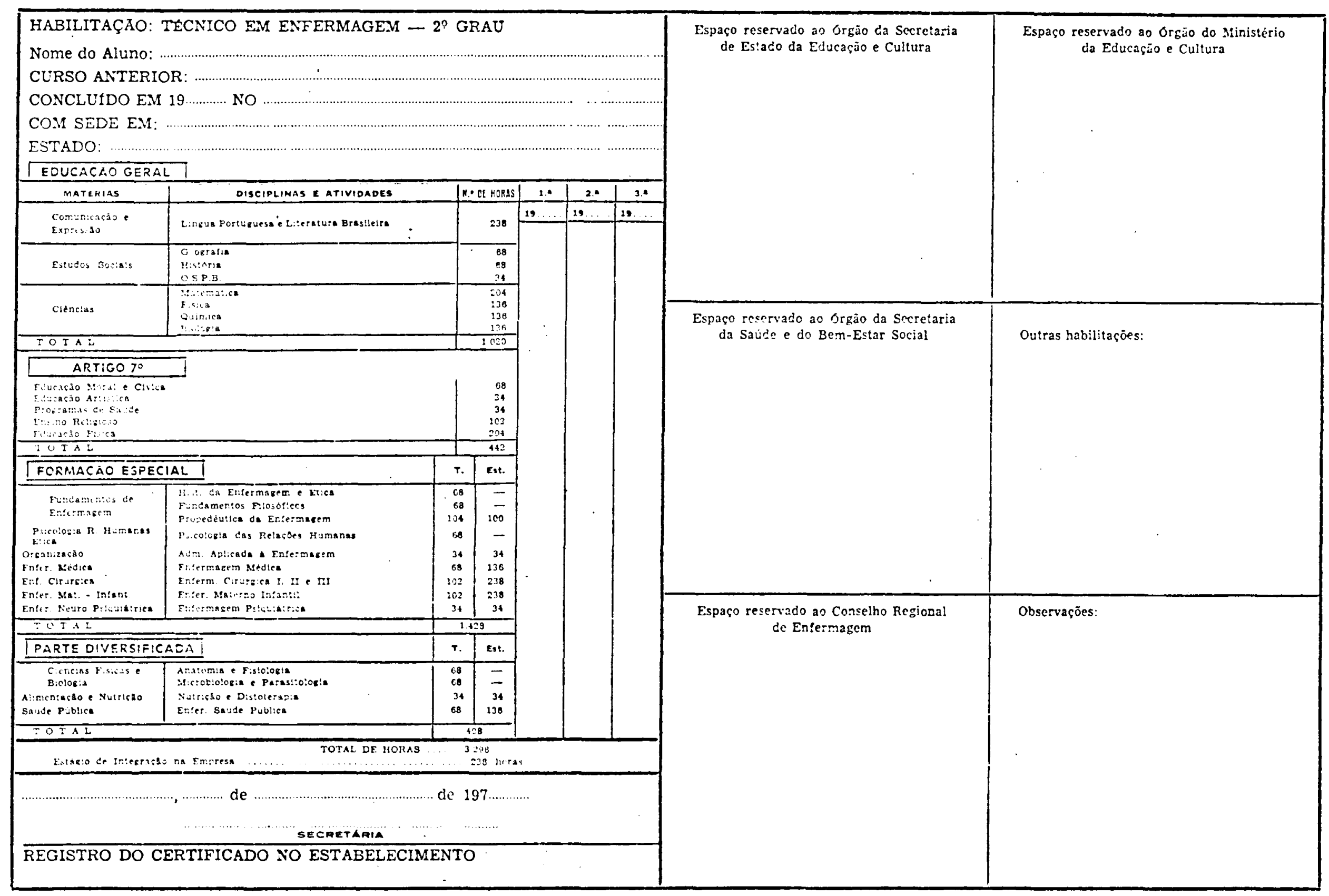




\section{ESCOLA TÉCHICA DE ENFERMAGEM CATARINA LABOURÉ}

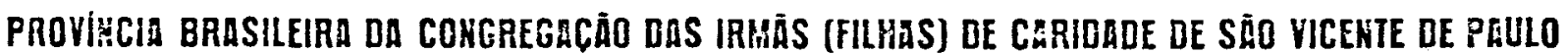

Autorizado pela Resolução $n^{9}$ 2.338/74 da Secretaria de Estado da Educação e da Cultura

do Estado do Paraná e Deliberação n⿳0 030 74 do Conselho Estadual de Educação.

\section{DIPLOMA DE HAMILITRCÃO PROFISSIONAL}

ENSINO DE 2.0 GRAU - SUPLETIVO

O Diretor da Escola Técnica de Enfermagem Catarina Labouré de acordo com os preceitos legais e de conformidade com os graus de aprovação em todas as disciplinas do CURSO TÉCNICO DE ENFERMAGEM concluido em........................................., por fitho(a) de

de... nascido(a) em ........... de

de $19 \ldots \ldots \ldots$, em

Estado , confere-the o titulo de Técnico de Enfermagem com base na Lei Federal n. ${ }^{\circ} 5.692$, de 11 de agosto de 1971 e legislação pertinente, para que possa gozar de todos os díreitos, regalies e prerrogativas concedidas a este titulo pelas leis do País.

Curitiba, Paraná, de de 19 


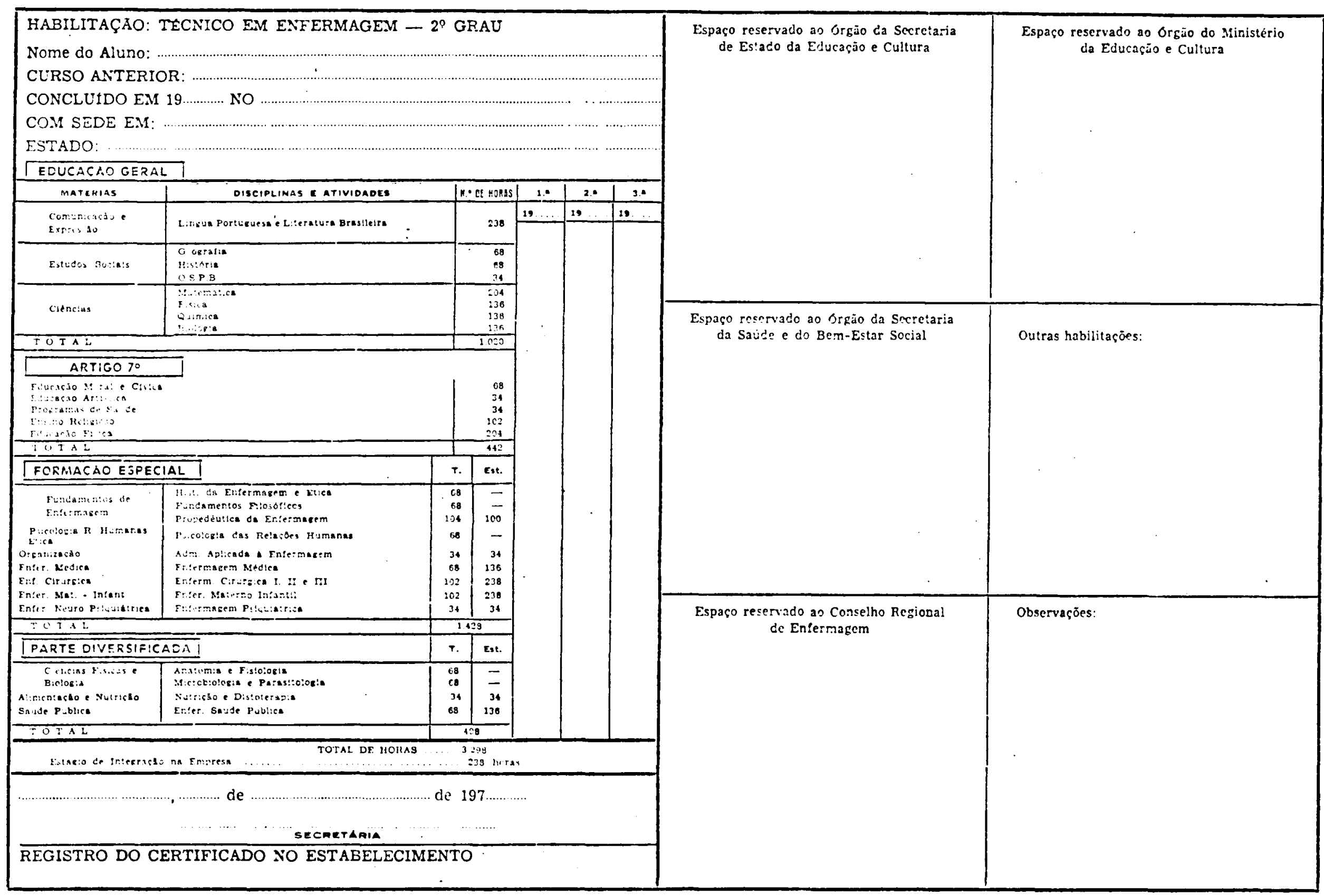




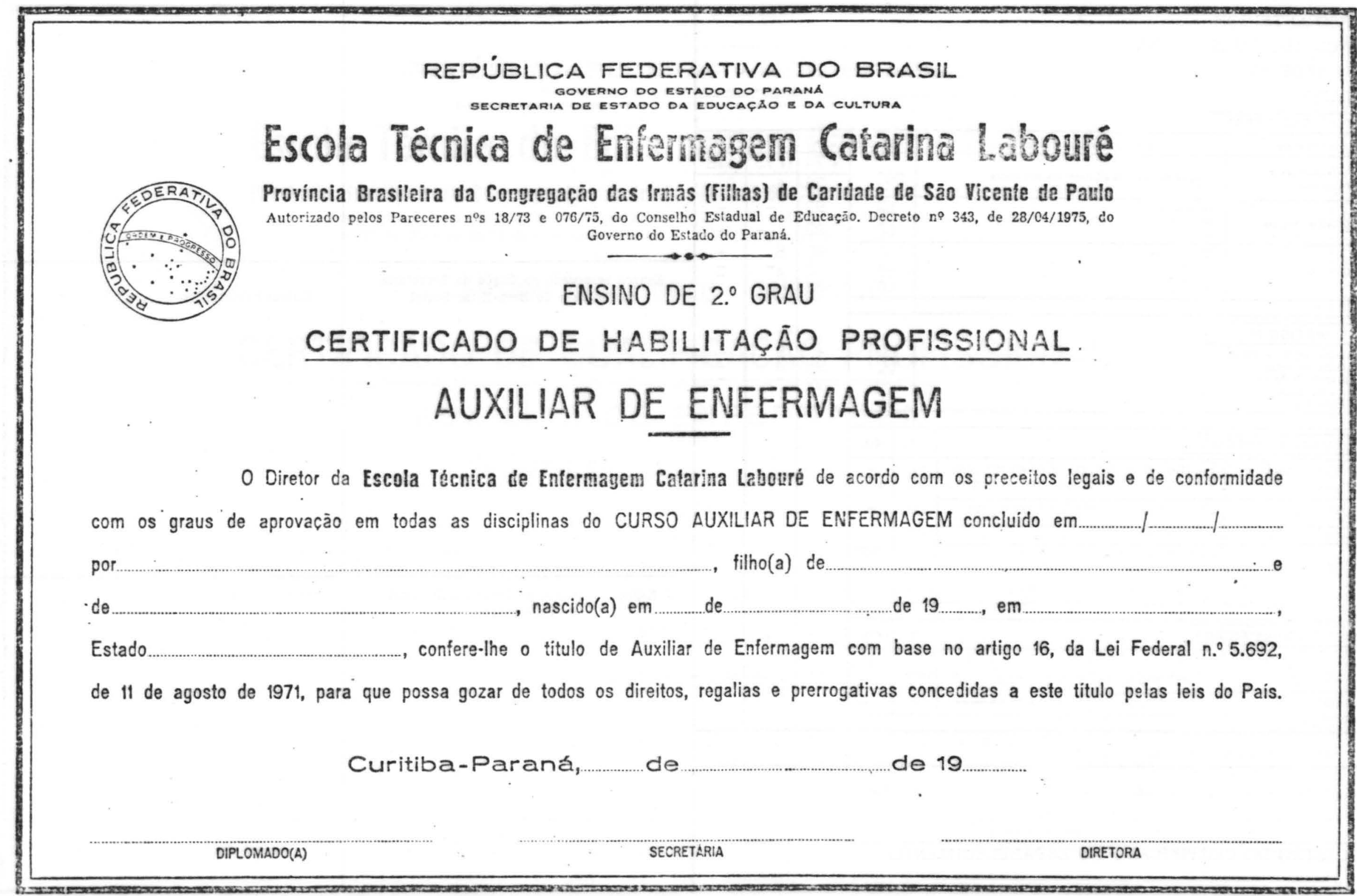




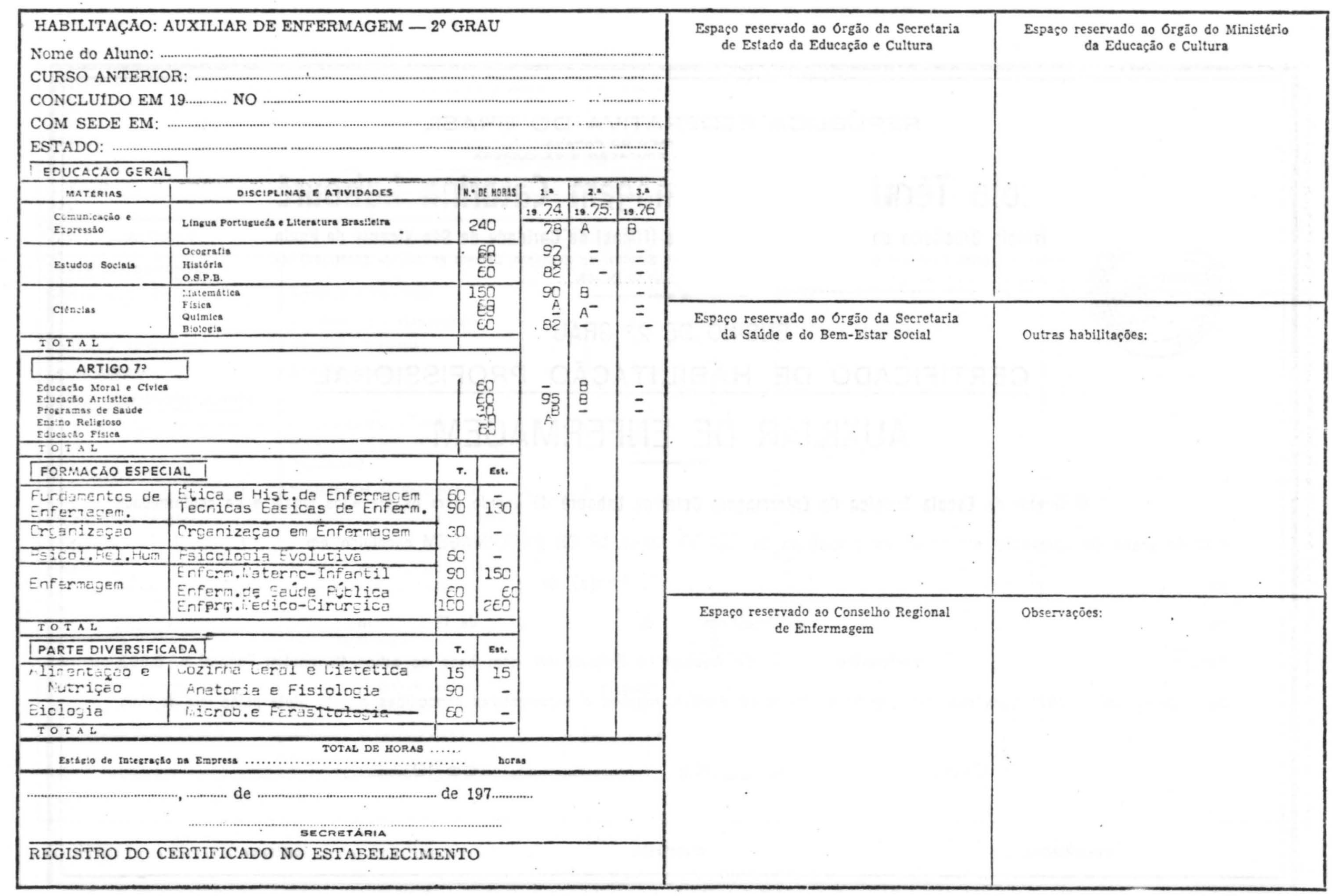


REPÚBLICA FEDERATIVA DO BRASIL

GOVERNO DO ESTADO DO PARANA
SECRETARIA DE ESTADO DA EDUCAGAOE DA CULTURA

\section{Escola Térnica de Enfemagem Cátaina Labouré}

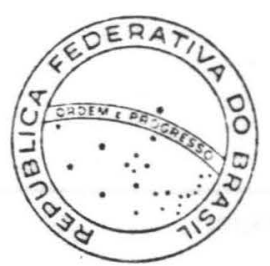

Provincia Brasileira da Congregação das Irmās (Fillıas) de Caridade de São Vicente te Paulo

Autorizado pela Resolução No 2.338/74 da Secretaria de Estedo da Educação e da Cultura do Estado do Paraná e Deliberação n? 30/74, Parecer. 36/74 do Conselho Estadual de Educação, Decreto n?

\section{ENSINO DE 2. GRAU - SUPLETIVO}

\section{CERTIFICADO DE QUALIFICACÃO PROFISSIONAL}

\section{AUXILIAR DE ENFERMAGEM}

de.

e de Naclonalldade)

natural de... Estado d

nascido(a) em de. de 19 . está capacitado (a) a exercer atividades de enfermagem, por ter concluido Curso Supletivo de QUALIFICAÇAO PROFISSIONAL EM ENFERMAGEM ao nivel de $2 .^{\circ}$ grau, sem direito a prosseguimento de estudos em nivel superior, nos termos da Lei 5.692 de 11/08/71 e legislação pertinente. Recebe o titulo de AUXILIAR DE ENFERMAGEM.

CURSO CONCLUÍDO EM Curitiba-Paraná, de de 19 CERTIFICADO EXPEDIDO EM de de 19 


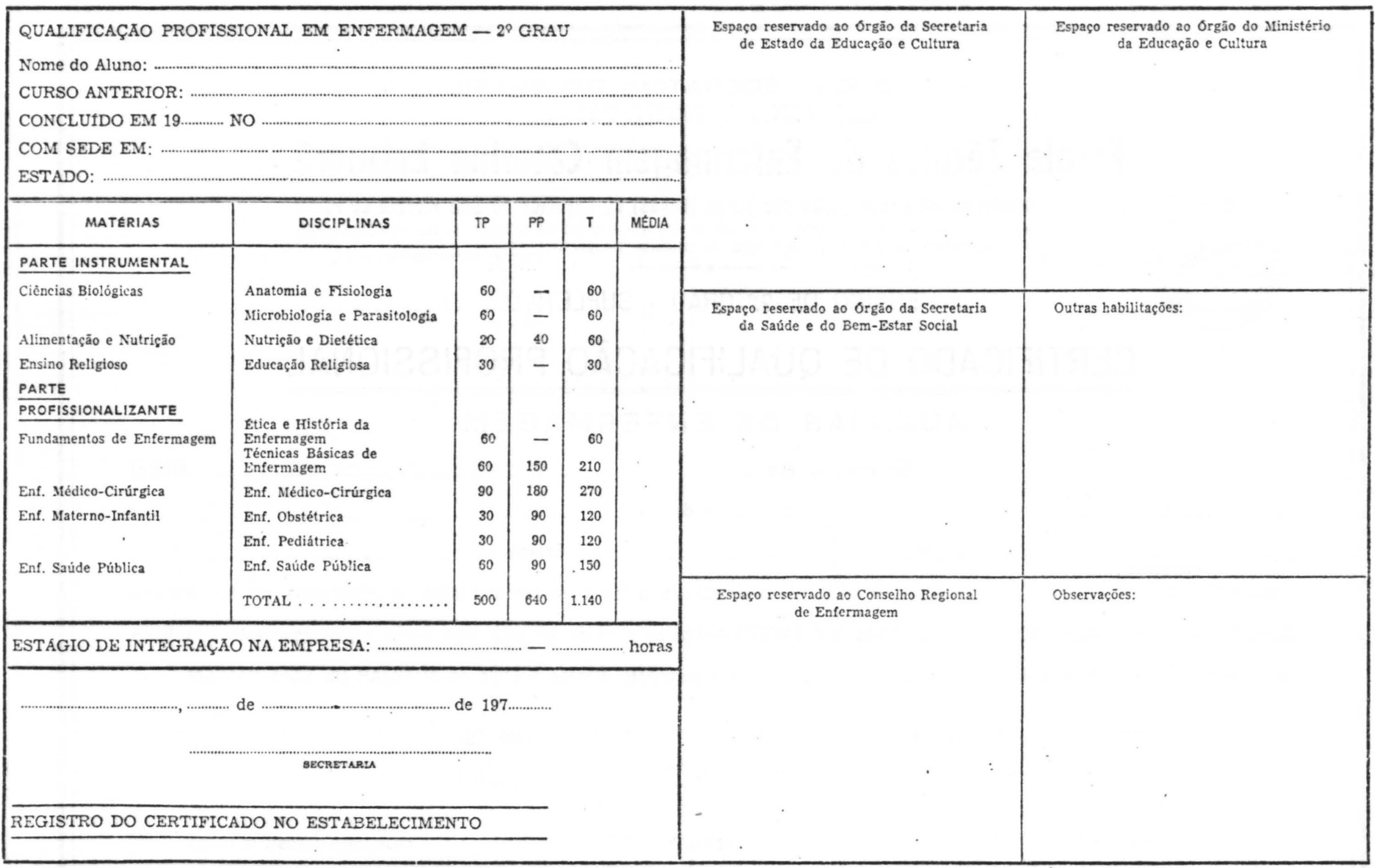


$A-18$

ANEXO - 4

ofícios 
Porto Alegre,12 de junho de 1973.

\section{Senhora Diretora:}

Venho por melo deste solic1tar a Vossa Senhorla a devida permissão, no sentido de poder efetuar uma pesquisa relativa a situaçăo de ensino de Enfermagem, a nfvel técnico e auxtliar, dessa Escola que, jun tamente com outros dados complementares do Estado do Paraná me darão subsf días necessártos à eleboração de monografla, que pretendo desenvolver sobreRecursos Humanos na Area de Enfermagem, requerida para a obtenção do grau de Mestra em Saúde Pública na Faculdade de Saúde Pública da Universidade de Gão Paulo, onde estou regularmente matriculada.

Agradecendo ćesde jả sua prestimosa colaboração ,

subscrevo-me

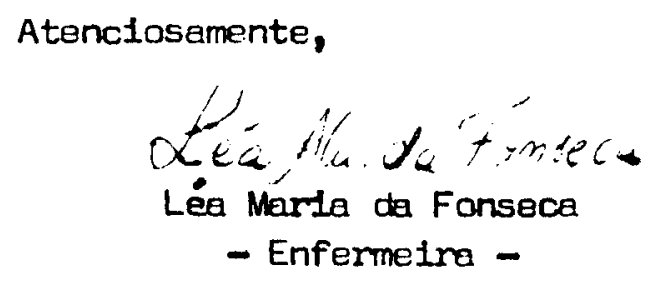

Ilma Senhora

Irmä Maria Turkiewicz

DD.Diretora da Escola Técnica de

Enfermagem Catarina Labouré.

Curdtiba - Paraná 
Senhora Enfermeira:

Acusamos o receblmento do seu offclo referente a solicitação da realização de un estudo sobre a situaçäo de ensino desta Es cola,bem como o leventamento de dados complementares sobre recursos assistenclais a humanos deste Estado, necessárlos à elaboraçäo de monografia do Curso de Mestrado que V.5\$ d,pretende concretizar.

Informamos que estamos de pleno acordo e oferece mos nossa colaboração, uma vaz que o estudo gm questäo se reveste de grande importâncla para o ensino de enfermagem a nivel técnico e auxiliar deste Estado،

Sendo o que temos a Iriformar, aproveitamos a ㅇ portunidade para relterar-lhe nossos protestos de consideraçāo e apreço.

Respeitosamente,

$$
\begin{gathered}
\text { Irma Marla Turkiewicz } \\
\text { - Diretora - }
\end{gathered}
$$

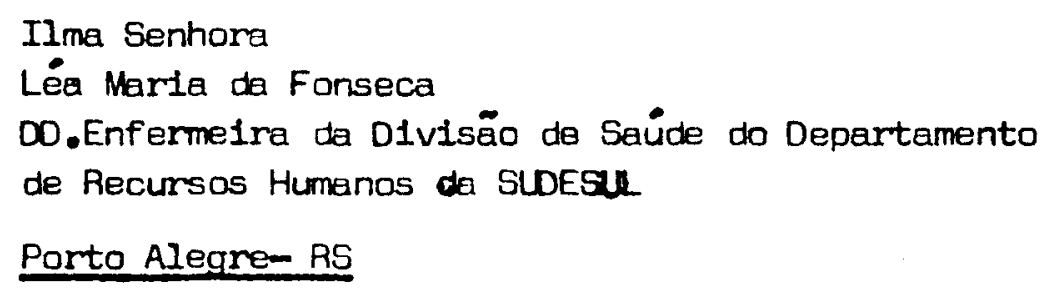


Senhor Orientador:

VImos por mio deste Informar a Vossa Senhoria que a Enfermetra Léa Marla da Fonseca,aluna do Curso de Pós-graduação em Saú de Pública a nfvel de Mestrado dessa Faculdade, esteve realizando uma pesquisa" In loco" sobre a s1tuação de ensino dos Cursos desta Escala,bem camo o le vantamento de outros dados do Estado do Parnná, necessários à claboração da monografia requerida para a obtenção do seu grau de Mestre.

Aproveitamos a oportunidade para informar a

V.S3.,que o trabalho desenvolvido pela referlda enfermelra será de grande u tılidade não só a nível desta Escola,como também no âmbito Estadual.

Sendo o que temos a Informar, aproveltamos a o partunidade para retterar-lhe nossos protestos de estima \& elevada considera ção.

Cordlalmente,

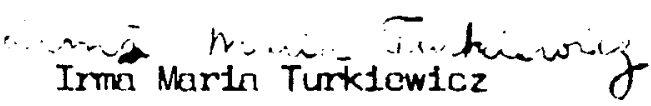

- Diretora -

IImo Senhor

Dr.Reinaldo Ramos

DD.Professor de Faculdade de

Saúde Pública da U.S.P.

São Paulo- 8F. 